\title{
المحبة لمخالف الملة
}

$$
\text { قراءة في الكتب المقدسة: اليهودية - المسيحية - الإسالامية }
$$

$$
\text { د. جمال الحسيني أبوفرحة }
$$

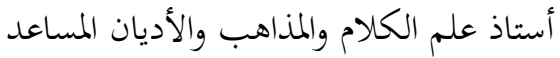

قسم الفلسفة. كلية الآداب. جامعة السـويس 
تحاول هذه الدراسة الإجابة على التساؤل التالي: ما موقف النصوص المقدسة في الأديان

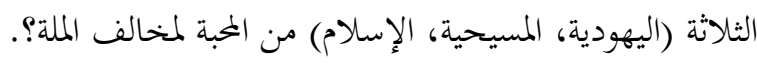
وتمدف هذه الدراسة إلى ما يلي: - ماس

تقليل حدة الخلاف بسد فجوة الزائف من الاختلاف بين أصحاب الأديان محل الدراسة.

ترسيخ التعايش المثمر البنّاء بين المؤمنين بأي من النصوص المقدسة موضع الدراسة وغيرهم.

الإسهام في تقديم ميزان عملي يمكن أن تقاس به صحة الأديان واكتمالها؛

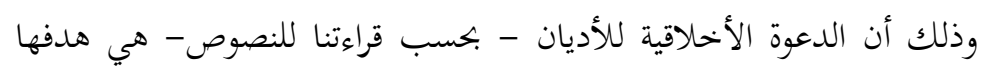

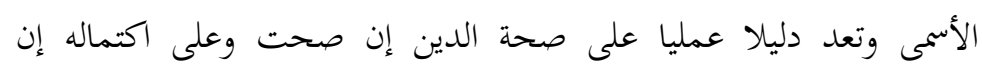

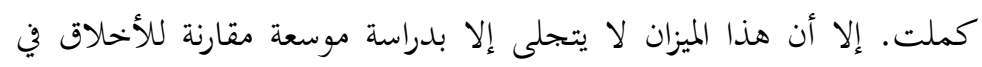

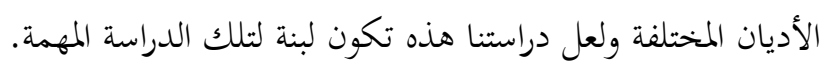

وتُعد هذه الدراسة - بحسب بحثي واستقصائي- الأولى في اللغة العربية بل والإنحليزية في موضوعها.

\section{Loving the unbelievers}

Reading in the Scriptures: Jewish - Christian - Islamic

By Jamal Elhosieny Abu Farha

This study attempts to answer the following question: What is the position of the sacred texts in the three religions Judaism, Christianity, Islam) from love to the unbelievers? 
This study aims to:

- Reducing the differences by closing the false gap between the different religions.

- Establishing fruitful and constructive coexistence among believers in any of the sacred texts studied and others.

- Contributing to the presentation of a practical balance that can be measured the validity and completeness of religions.

This study is, according to my research, the first in Arabic and even English in its subject 
بدأ مصطلح "صناعة الأعداء" في الازدهار بعد انتهاء الحرب الباردة بين المعسكرين الشرقي والغربي، وبجرأة غير متوقعة أصبحنا نسمع حديثا معاصرا يبرر العداوة للآخر لمحرد أنه آخر من أجل مصالح بحتمعية(1)، وسياسية(2)، واقتصادية(3) وبالإضافة لتلك المصالح كانت هناك مشكلات ثقافية(4) ولغوية(5) تدعم هذه العداوة، ولا يغيب الاستعلاء العرقي والبواعث النفسية

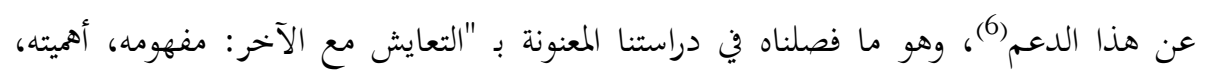

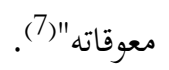

لكن العداوة ليست مغنما! والصداقة ليست مغرما!. ولم يعد أمام أبناء آدم خيار في التعايش مع بعضهم البعض ما تحققت ركائز التعايش - من عدل وحرية وحوار وإحسان- إن لم يكن لتحقيق المغانم المرجوة فدرءا للمغارم والمخاطر المحدقة التي تمددهم جميعا!. فما أحوج البشرية لاستبدال صناعة الأصدقاء بصناعة الأعداء!

وإسهاما منا في ذلك، وبحكم تخصصنا في دراسة الأديان، كان وقوفنا أمام التأصيل الديني للعلاقة بين المؤمنين والكفار في الأديان الإبراهيمية الثلاثة، فجاءت دراستنا هذه - كحلقة في سلسلة دراسات لنا حول هذا الموضوع- لتسلط الأضواء على النصوص المقدسة المتعلقة بالمحبة لمخالف الملة محاولة منا للوقوف على حقيقة دعوة الأديان الإبراهيمية الثلاثة إلى التعايث المثمر البناء مع مخالف الملة، هل تدعمه أم تنقضه؟!

وبقدر التوازن النفسي الذي تطرحه نصوص الأديان المقدسة وما ينبثق عنه من مشاعر إنسانية وأخلاق حميدة تسعى لتتجسد عمليا في مجموعة من الممارسات العملية تتمايز الأديان: فيتضح باطلها من صحيحها، ومكتملها من ناقصها؛ ومن ثمة تتجلى أهمية دراستنا هذه؛ فالمحبة ليست بحرد شعور داخلي بمعزل عن الأخلاق العملية. 
فإن تشاهت أديان في دعم هذا الشعور بتحاه الآخر، فلا شك أن لفت الانتباه إلى بعض

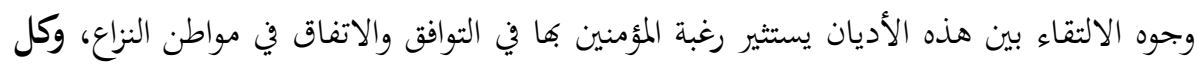
ذلك يدعم الحق ويرسخ التعايش، وهو ما تصبو إليه دراستنا هذه.

وإن لم توجد نصوص في دين ما تحث على الخحبة لمخالف الملة، أو لم تدل النصوص

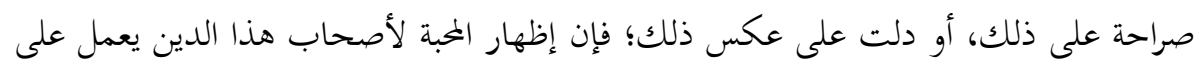

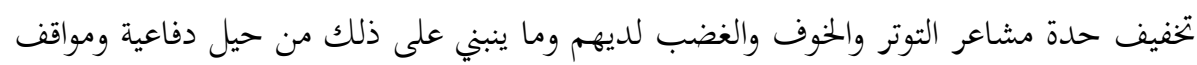

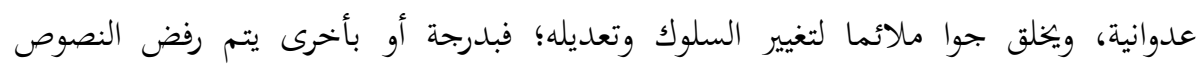

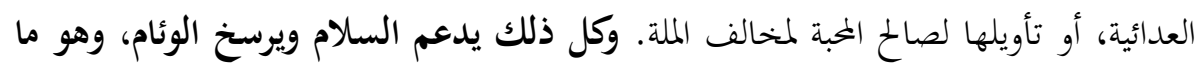
تصبو إليه دراستنا هذه.

ودراستنا هذه عن المحبة تدور حول ركيزة من ركائز التعايش ألا وهي الإحسان؛ وذلك أن

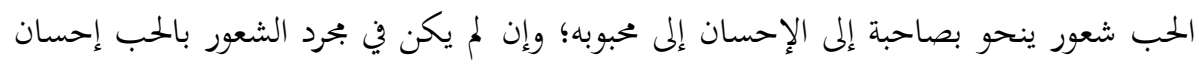

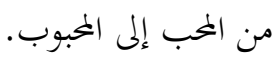
مدخل إلى الدراسة حدود الدراسة. أسئلة الدراسة. أهداف الدراسة. منهج الدراسة وضوابطها. مصطلحات الدراسة. الدراسات السابقة. تقسيم الدراسة.

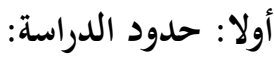


لقد آثرنا تخصيص دراستنا هذه بـ "مخالف الملة" لما يلي:

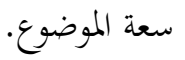

إن محبة مخالف الملة موضع خلاف ونزاع عند أصحاب الأديان محل الدراسة.

إن خخالف الملة - في الأعم والأغلب عبر التاريخ- كان معاديا بدرجة أو بأخرى؛ ومن ثمة فتحقق

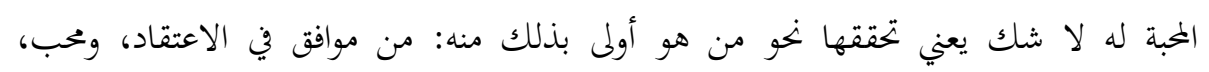
وحليف... (لخ.

ثانيا: أسئلة الدراسة:

تحاول هذه الدراسة الإجابة على التساؤل التالي:

ما موقف النصوص المقدسة في الأديان الثلاثة: (اليهودية، المسيحية، الإسلام) من الحمبة لمخالف الملة؟.

ثالثا: أهداف الدراسة:

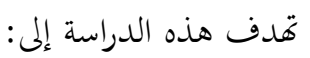

أ- تقليل حدة الخلاف بسد فجوة الزائف من الاختلاف بين أصحاب الأديان محل

$$
\text { الدراسة. }
$$

ب- ترسيخ التعايش المثمر البنّاء بين المؤمنين بأي من النصوص المقدسة موضع الدراسة وغيرهم.

ت- - الإسهام في تقديم ميزان عملي يمكن أن تقاس به صحة الأديان واكتمالها؛ وذلك أن

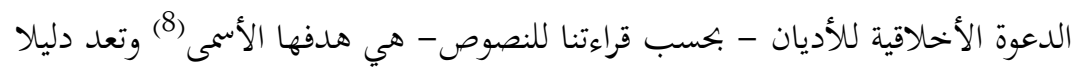

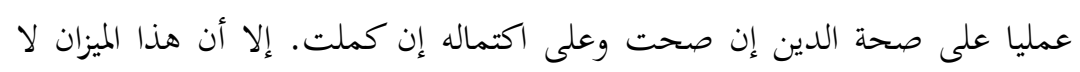


يتجلى إلا بدراسة موسعة مقارنة للأخلاق في الأديان المختلفة ولعل دراستنا هذه تكون لبنة لتلك الدراسة المهمة.

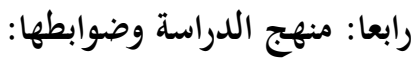

ومنهجنا في هذه الدراسة هو: المنهج الاستقرائي التحليلي الاستباطي النقدي المقارِن للنصوص المتعلقة بموضوع البحث.

وفي دراستنا هذه آثرت الترتيب الزمني في العرض بقدر الإمكان فابتدأت بالنصوص

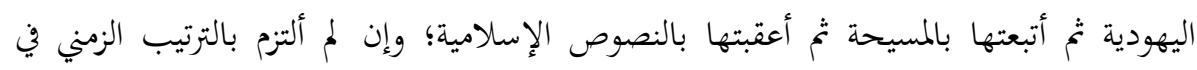

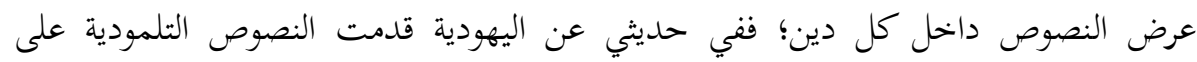

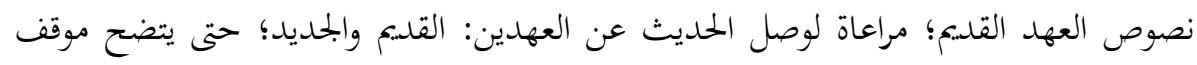

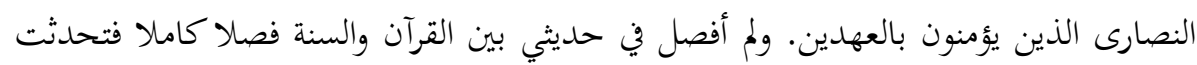
عنهما تحت عنوان موحد هو قراءة في النصوص الإسلامية لتداخل الحديث في كثير من الأحيان

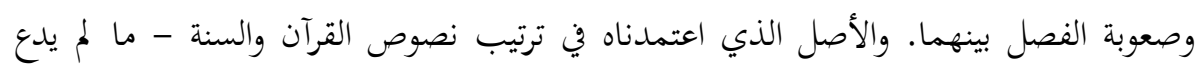
داع إلى خلاف ذلك- هو تقديم السنة على القرآن انطلاقا من إيماننا بأولوية ترتيب الأدلة تصاعديا من الأضعف إلى الأقوى(9).

وقد كان اعتمادنا على نصوص الكتاب المقدس في الطبعة المنشورة على الموقع الإلكتروني

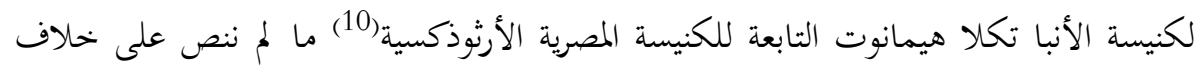
ذلك.

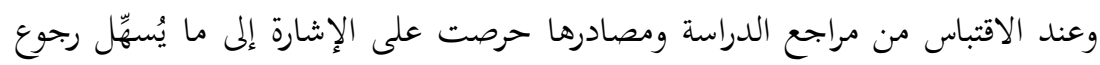

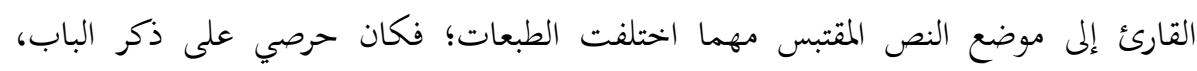
والفصل....الخ، أكثر من حرصي على ذكر ما يتغير بتغير الطبعات. خامسا: مصطلحات الدراسة: - ( مخالف الملة: ونقصد به كل من خالف غيره في ركن من أركان إيمانه. 
محبة مخحالف الملة: لا يمكننا الانطلاق في تعريف محبة مخالف الملة من مفاهيم دينية محددة سلفا؛ فالمفهوم الديني محبة مخالف الملة هو موضع نزاع في دراستنا هذه، تحدده الدراسة ولا تتحدد

القراءة العلمية للنصوص المقدسة: نزعم أن قراءة فقهية أيا ما كانت لا يمكن أن تعد مثثلة

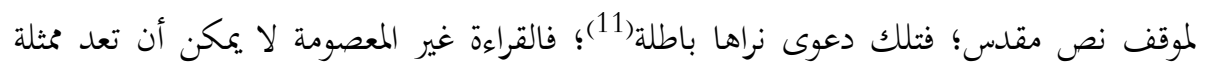
لنص مقدس. ولا يعني ذلك غياب الحق وضياع الحقيقة بين الآراء إذا اختلفت، وإنما يُلزم الإنسان بقناعته التي يتحصل عليها بعد صدق العزم وبذل الجهد المناسب.

\section{الكتب المقدسة اليهودية، وهي: (التلمود، والتناخ).}

والتلمود: كلمة عبرية معناها التعلم(12)، وينقسم إلى قسمين: الأول: المشنا: وهي بحموعة

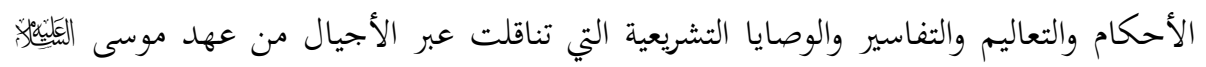

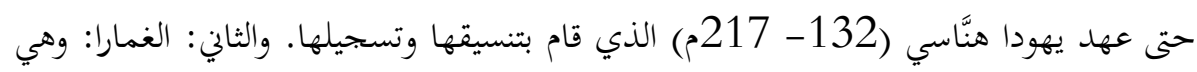

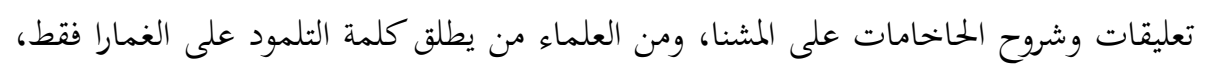

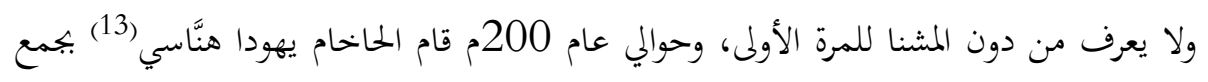

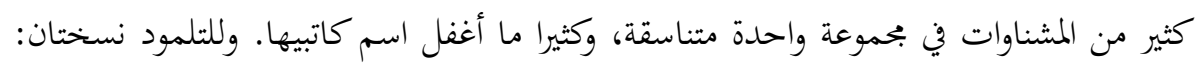

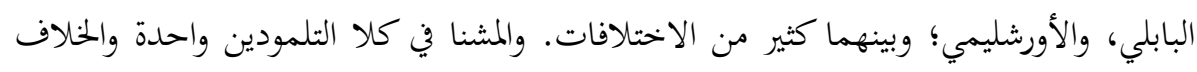

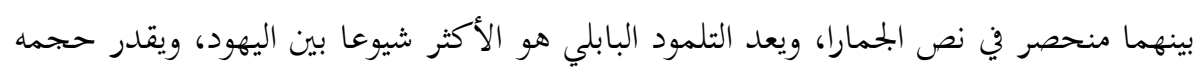

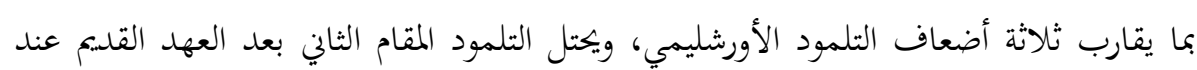
عامة اليهود، ومنهم من يرفضه كالسامرة والصدوقيين والقرائين(14).

والتناخ: يقصد به: كل من: أسفار التوراة، وأسفار الأنبياء(15)، وأسفار الحكمة أو الكتابات؛

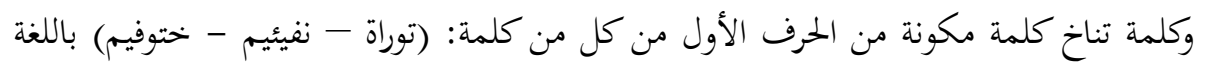

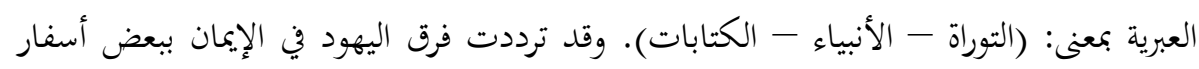

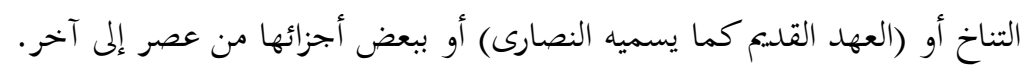

$$
\text { 4- الكتب المقدسة المسيحية: وهي: (العهد القديم، والعهد الجديد). }
$$


العهد القديم: لعل بولس الرسول(16) هو أول من أطلق هذه التسمية على الأسفار المقدسة التي يسميها اليهود بالتناخ(17)، وتابعه النصارى في ذلك الإطلاق ليشيروا بذلك إلى أن هناك عهدا آخر جديدا يتكون من الأسفار المسيحية المقدسة لديهم. وبالطبع يرفض اليهود هذه التسمية لأن موافتتهم تعني إيمافم بعهد جديد جاء بعد عهدهم. وقد ترددت فرق النصارى في الإيمان ببعض أسفار العهد القديم وببعض أجزائها من عصر إلى آخر، وقد كان اختيارنا للاسم النصراني لهذه بهان الأسفار لاشتهارها به أكثر من اشتهار الاسم اليهودي(18).

والعهد الجديد: هو ما يؤمن به النصارى وحدهم؛ ويتكون من سبعة وعشرين سفرا، وهو عبارة عن: أربعة أناجيل (متى، مرقس، لوقا، يوحنا)، وسفر أعمال الرسل، وبحموعة رسائل بولس الرسول وعددها أربع عشرة رسالة، وبحموعة الرسائل الجامعة وعددها سبع رسائل، وأخيرا رؤيا يوحنا اللاهوتي.

$$
\text { 5- الكتب المقدسة الإسلامية: وهي: (القرآن، والسنة). }
$$

والقرآن لغة: مصدر، بمعنى القراءة، وفي اصطلاح علماء الإسلام: هو كلام الله المعجز، المنزل على رسوله عليهوسلم ، المتعبد بتلاوته، المنقول إلينا بين دفتي المصحف تواترا من أول سورة الفاتحة إلى آخر سورة الناس(19).

والسنة في اللغة: الطريقة والسيرة حسنة كانت أم سيئة(20) والتعريف الإجرائي المختار لها في بحثنا هذا هو التعريف الاصطلاحي لها عند علماء أصول الفقه، وهو أفا: ما صدر عن النبي عليهوسلم من قول أو فعل أو تقرير(21)، مما يصلح أن يكون دليلا للحمى شرعي. سادسا: الدراسات السابقة: - n تُعد هذه الدراسة - بحسب بحثي واستقصائي- الأولى في اللغة العربية بل والإبحليزية في موضوعها. سابعا: تقسيم الدراسة: 
اقتضت طبيعة هذه الدراسة أن تأتي في مقدمة، ومدخل، وأربعة مباحث، وخاتمة، وفهرس للمصادر والمراجع، وفهرس للمحتويات. أما المقدمة: فقد تحدثت فيها عن أهمية الدراسة. وأما مدخل الدراسة: فبينت فيه حدود الدراسة، وأسئلتها، وأهدافها، ومنهجها، وضوابطها، ومصطلحاتا، والدراسات السابقة لها، وتقسيمها. وأما المبحث الأول فقد عرضت فيه قراءتي للنصوص التلمودية المتعلقة بموضوع الدراسة. وأما المبحث الثاني فقد عرضت فيه قراءتي لنصوص العهد القديم المتعلقة بموضوع الدراسة. وأما المبحث الثالث فقد عرضت فيه قراءتي لنصوص العهد الجديد المتعلقة بموضوع الدراسة. وأما المبحث الرابع فقد عرضت فيه قراءتي لنصوص القرآن والسنة المتعلقة بموضوع الدراسة. وفي الخاتمة عرضت ملخصا للدراسة، ثم حللت نتائجها. وفي غاية الدراسة عرضت فهرسا للمصادر والمراجع تم فهرسا للمحتويات. أسأل الله تعالى أن أكون قد وفقت وأن ينفعني بهذا العمل في آخرتي ودنياي، وينفع به. المبحث الأول

\section{التلمود والمحبة لمخالف الملة}

لم يمكننا الوقوف على مفهوم محدد للحب في التلمود سواء انطلاقا من لغته (العبرية) أو

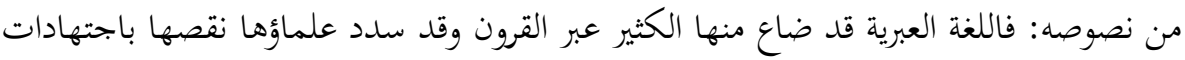
واقتباسات من هنا وهناك. ومن ثمة لم تعد حجة في بيان مفهوم كمفوم الحب. ورغم أن لفظة

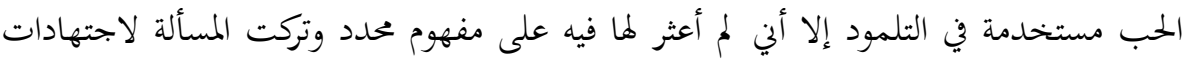


ولعل من أهم وأشثل تعريفات الحاخامات للحب تعريف الحاخام ستينسالتز حيث يقول:(22)"في الاستخدام الشائع بحد أن كلمة الحب تستخدم أحيانا للتعبير عن الإعجاب فقط،

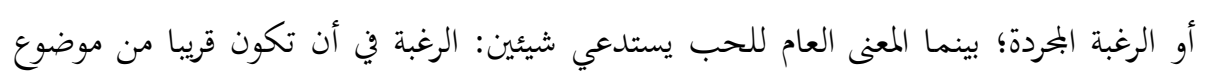

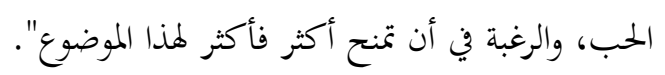

وفيما يتعلق بمحبة مخالف الملة لم أعثر في التلمود سوى على نص واحد يأمر بمحبة الخلق أجمعين بصرف النظر عن انتمائهم الديني؛ يقول التلمود:(23)"كن..... محبا للخلق". وفي الاتجاه المقابل نجد نصوصا كثيرة في التلمود تناقض عمليا محبة مخالف الملة؛ فيُكال له بيكل غير ذلك الذي يكال به لليهودي؛ ومن ذلك قول التلمود: "إذا وجد الإسرائيلي ... [ بالمدينة] لقطة وكانت الأغلبية من الجوبيم(24)، فلا يجب علي عليه أن يعلن عنها، وإذا كانت

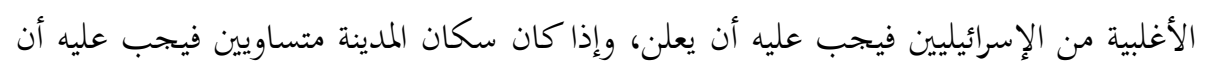

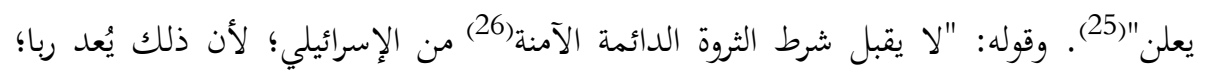

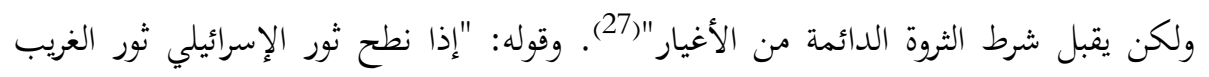
(غير اليهودي) فإنه يُعفى، أما إذا نطح ثور الغريب ثور الإسرائيلي فسواء كان غير مؤذ أو مشهود الضرر يعوّض

(غير اليهودي اليهودي) عن الضرر كاملا"(28). وتفصيل الكلام في ذلك يحتاج إلى دراسة مستقلة عن العدل. وفي مستخلص الدراسة لنا وقفة متأنية حول هذا التناقض وهذه الازدواجية الأخلاقية. المبحث الثاني

العهد القديم والمحبة لمخحالف الملة

لم يمكننا الوقوف على مفهوم محدد للحب في العهد القديم سواء انطلاقا من لغته (العبرية) أو من نصوصه: فاللغة العبرية قد ضاع منها الكثير عبر القرون وقد سدد علماؤها نقصها معاديا باجتهادات واقتباسات من هنا وهناك كما سبق بيانه، ورغم أن لفظة الحب مستخدمة في العهد القديم إلا أني لم أعثر لها فيه على مفهوم محدد. 
ويفسح العهد القديم مكانا لمحبة الناس جميعا بصرف النظر عن دينهم:

فينفر من الحقد والحسد والكراهية؛ فيقول:(29)"القلب المطمئن يهب أعضاء الجسد حياة،

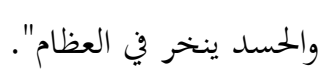

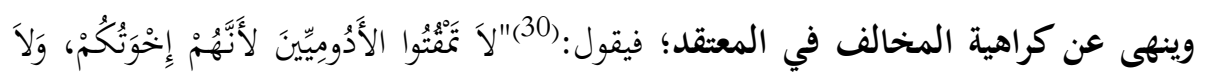

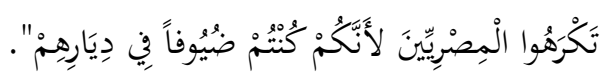

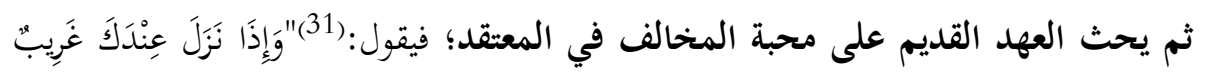

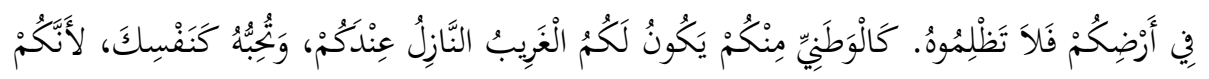

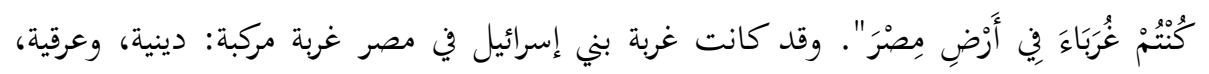

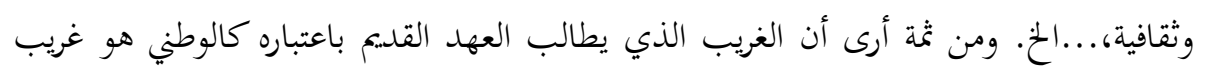

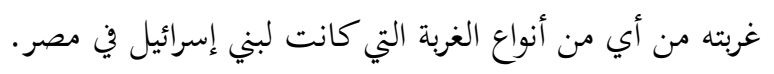

ويُغري العهد القديم بمحبة الناس أيا كان دينهم فيجعلها من لوازم الصديقين فيقول:(32)"إنَّ

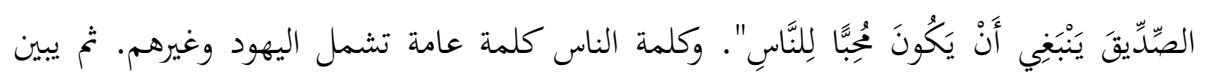

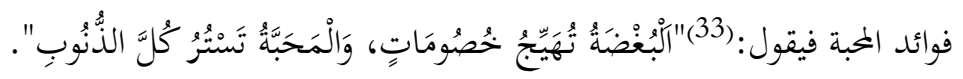

ويربط العهد القديم بين المحبة لجميع الناس والحكمة؛ فيربط بين محبة الله للبشر

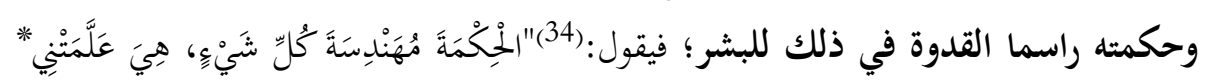

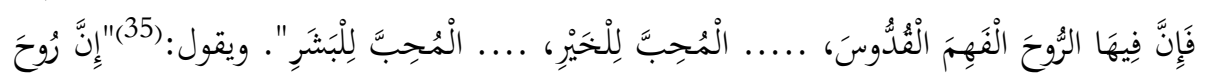

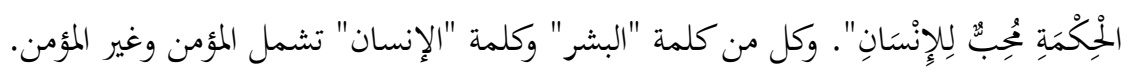

ويرسم العهد القديم القدوة بالرب تعالى في محبة مخالف الملة، معللا لمحبة الرب له؛

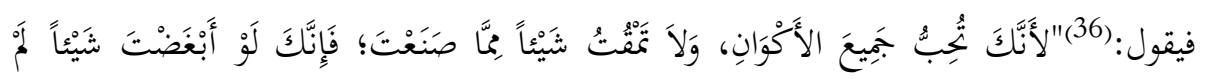

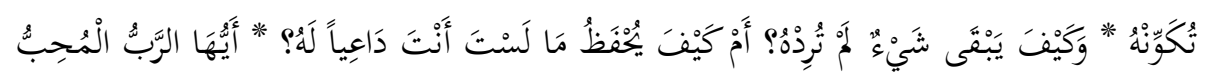

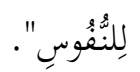

ويأمر العهد القديم المؤمنين بمحبة مخالف الملة، معللا أمره لهم بأمرين: أولا: الاقتداء بالرب. ثانيا: اتباع القاعدة 
الذهبية للتعايش (ما لا تحب لنفسك لا تصنعه لغيرك)(37)؛ فيقول:(38)"الرَّبَّ إِلَّكُمْ هُوَ إِلهُ الآلِمِةِ

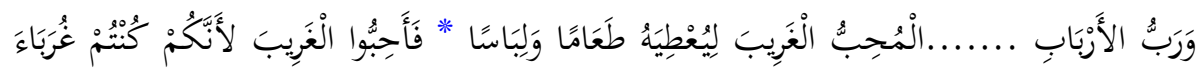
في أَرْضِ مِصْرَ". وغربة بني إسرائيل في مصر - كما قلنا- كان البعد الديني حاضرا فيها بقوة وهو الأهم فيما يتعلق بموضوع دراستنا.

وفي الاتجاه المقابل نجد نصوصا كثيرة في العهد القديم تناقض عمليا محبة مخحالف الملة؛

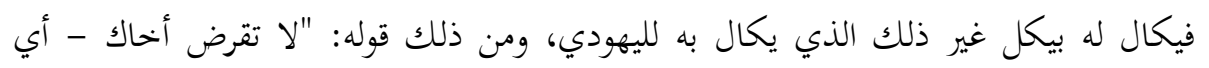

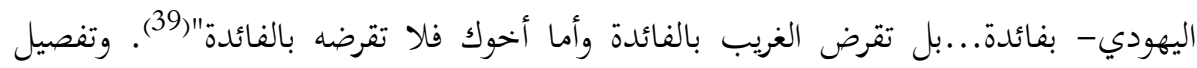
الكلام في ذلك يحتاج إلى دراسة مستقلة عن العدل.

وفي مستخلص الدراسة لنا وقفة حول هذا التناقض وهذه الازدواجية الأخلاقية. المبحث الثالث

العهد الجديد والمحبة لمخالف الملة

لم يمكننا الوقوف على مفهوم محدد للحب في العهد الجديد انطلاقا من لغته الأصلية (الآرامية) وهي لغة لم يتبق منها إلا القليل، وعوضا عن ذلك كانت نصوص العهد الجديد واضحة الدلالة على مفهوم الحب في المسيحية.

فالمحبة في مفهوم النصوص المسيحية المقدسة هي سلوك عملي أولا وأخيرا؛ يقول

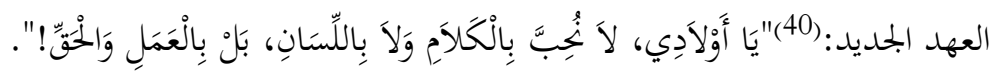

وهذا السلوك العملي هو التضحية والبذل والعطاء دون انتظار للأخذ؛ يقول العهد

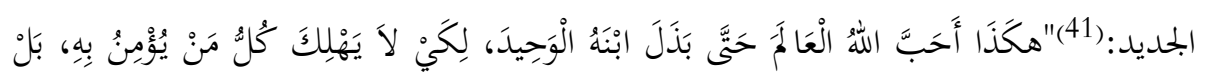

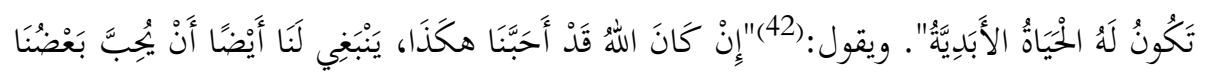

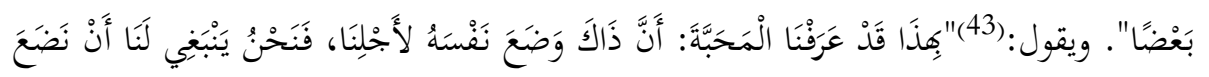

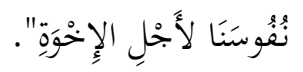


فالمحبة في المسيحية بين البشر تسير على نمط حب الله للبشر كما عبر عنه

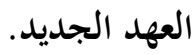

ويقسم العهد الجديد المحبة إلى قسمين متلازمين: محبة الله، ومحبة الناس جميعا

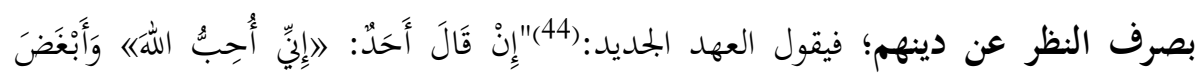

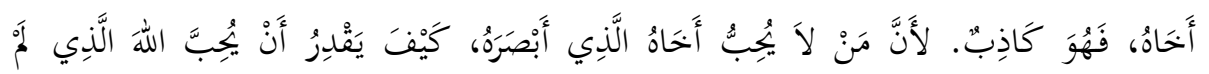

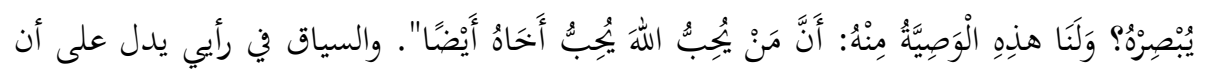

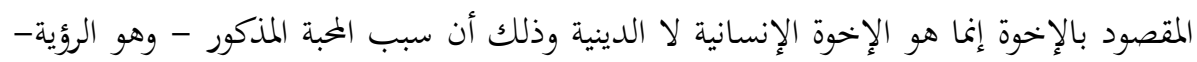

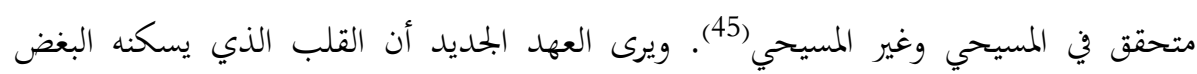

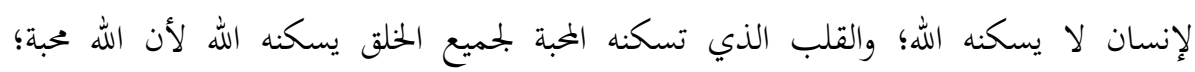

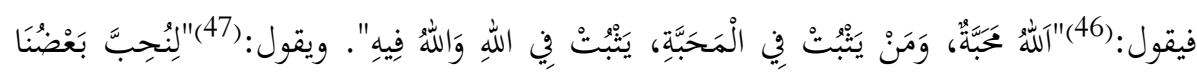

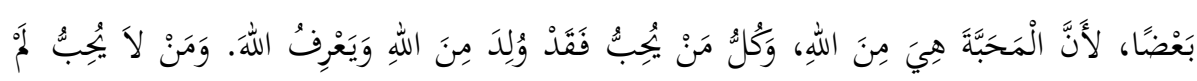

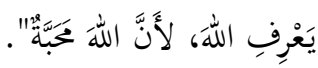

ويرسم العهد الجديد القدوة لمحبة الناس جميعا بصرف النظر عن دينهم ويأمر بها؛

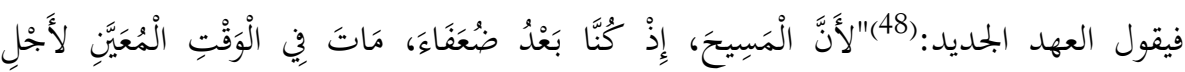

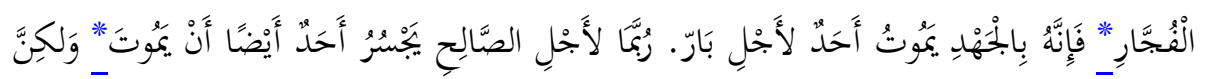

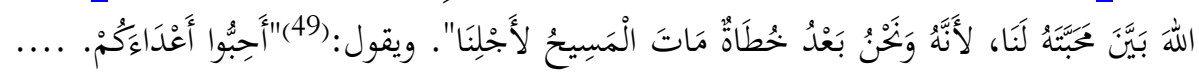

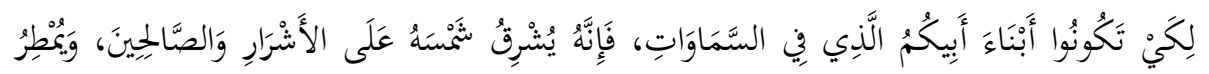

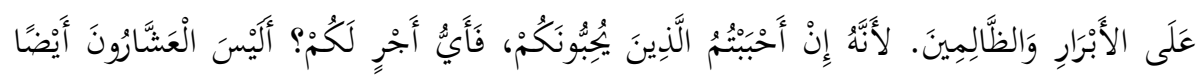

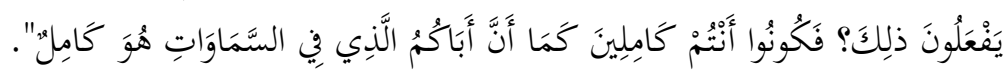

ويعلي العهد الجديد من شأن المحبة؛ فيجعلها غاية الوصية؛ فيقول:(50)"غَايَةُ الْوَصِيَّة

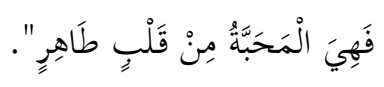

ويجعل من محبة الناس جميعا- بصرف النظر عن انتماءاتهم الدينية- الوصية الثانية

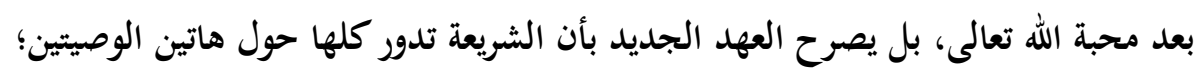

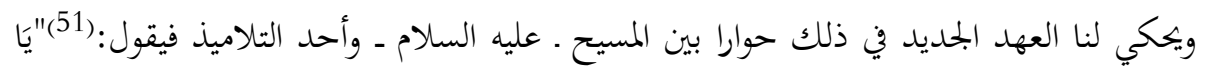




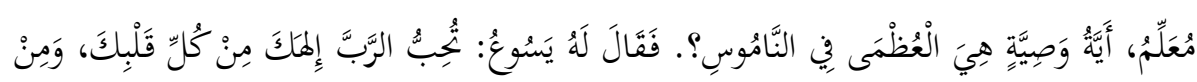

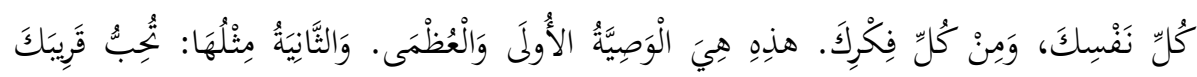

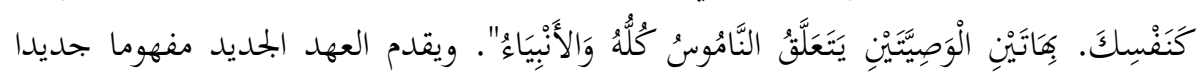

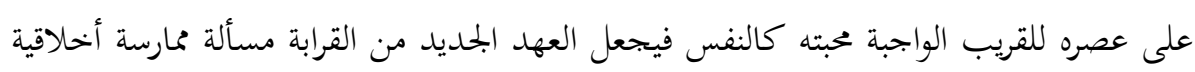

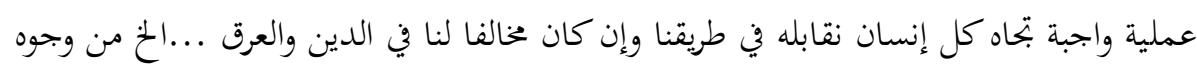

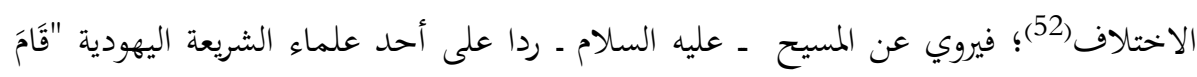

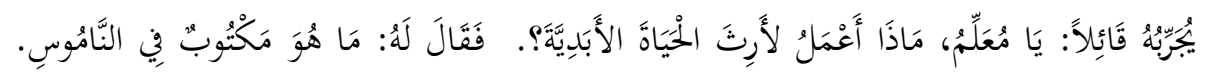

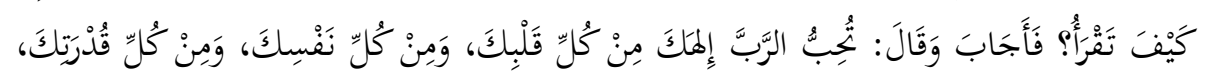

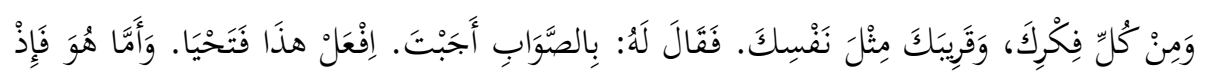

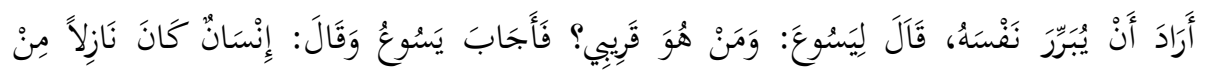

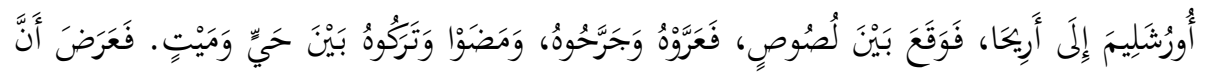

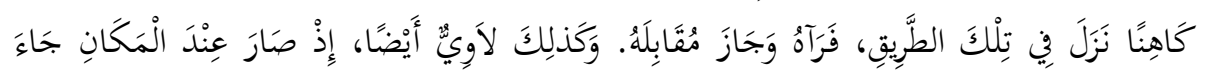

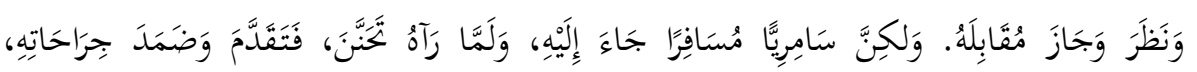

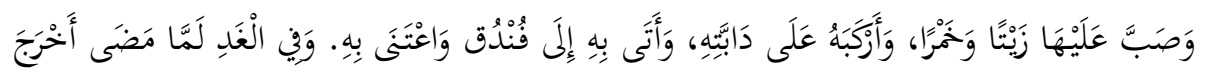

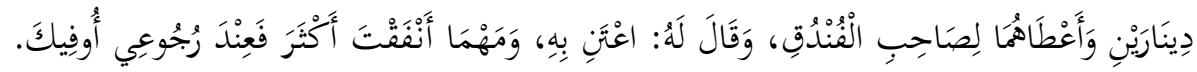

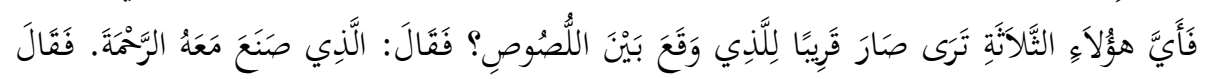

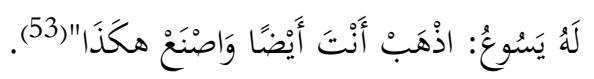

وبدون محبة الناس لا يكتمل الناموس؛ يقول العهد الجحيد:(54)"مَنْ أَحَبَّ غَيْرَهُ فَقَدْ

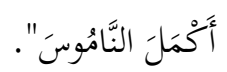

بل إن العهد الجديد ليرى المحبة أعظم من الإيمان وأعظم من الرجاء

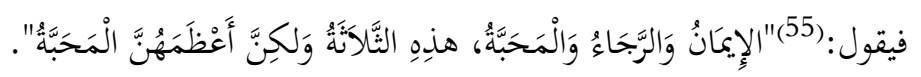

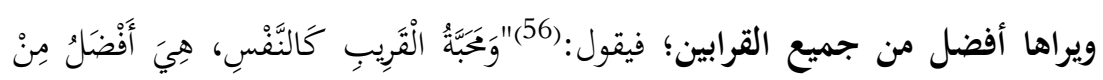

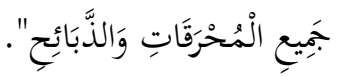


فهي جامعة الفضائل لا يحتاج المؤمن بعدها إلى وصايا أخري، فالمحبة تكفيه وتغنيه، يقول

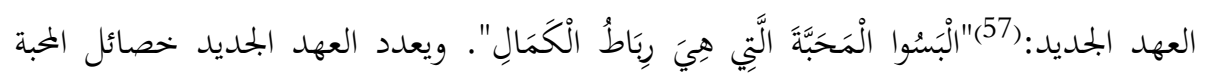

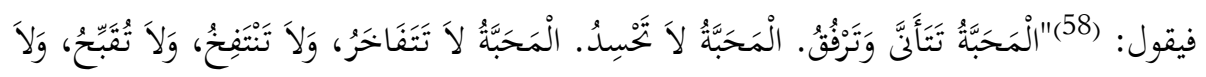

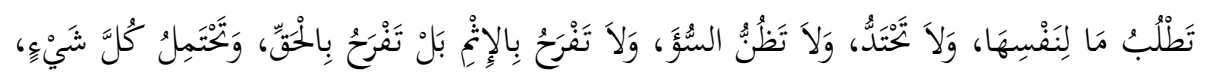

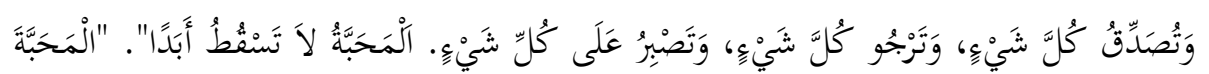
تَبْنِي "(59).

وهي روح كل عمل فاضل وبدونها لا قيمة لفضيلة أيا ما كانت؛ يقول

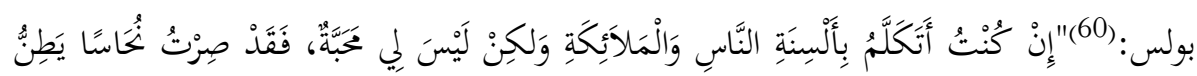

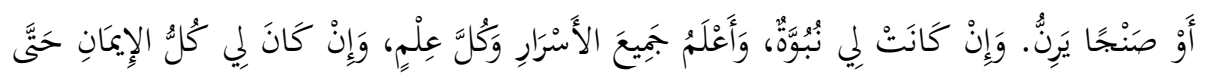

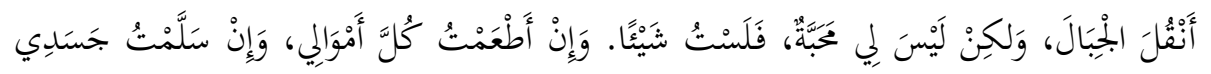

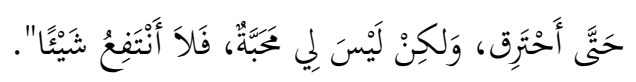

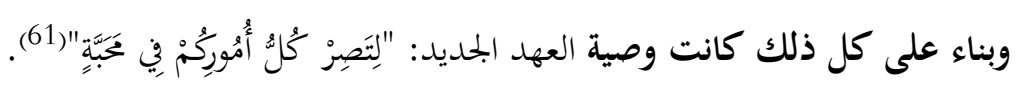

وقبل كل شيء لا ينس العهد الجديد أن يُفسح للمحبة مكانا؛ فنفر من الكراهية

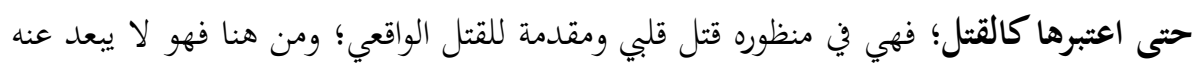

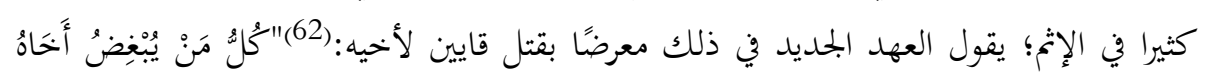

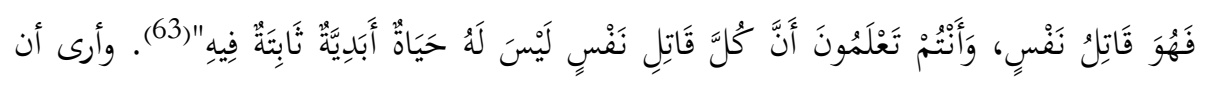

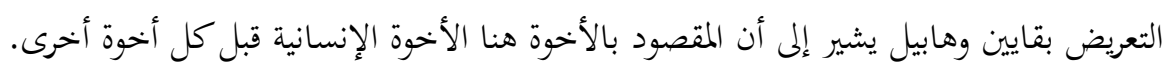

\section{المبحث الرابع}

نصوص الإسلام والمحبة لمخالف الملة

الحب ومرادفاته بيّن المعنى واضح الدلالة في لغة الإسلام (العربية) ولم تتجاوز

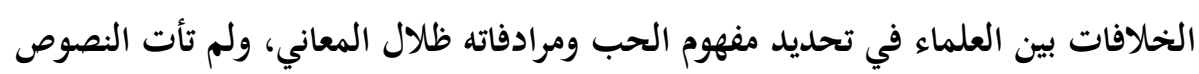
الإسلامية المقدسة بمعاني اصطلاحية للحب ومرادفاته مخالفة للمعانى اللغوية. 
فبالنظر في معاني مادة (ح ب ب) في لغة الوحي الإسلامي - العربية- بند ما

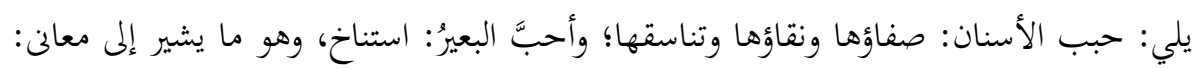

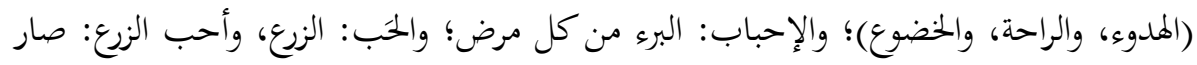

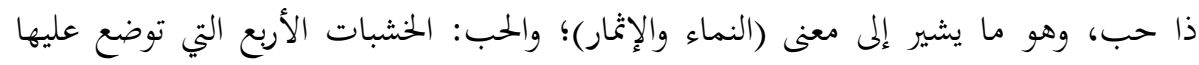

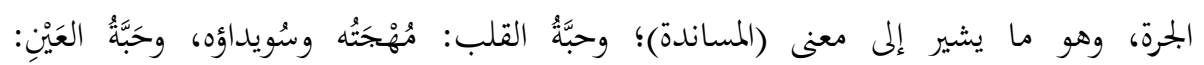

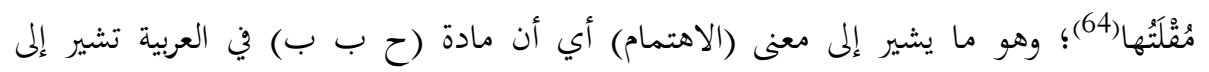

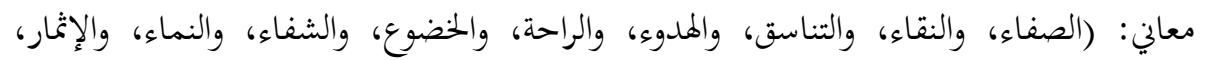

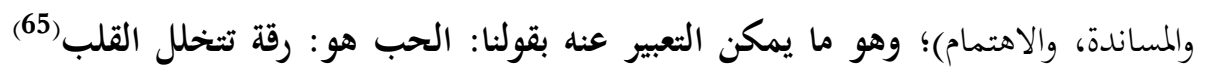

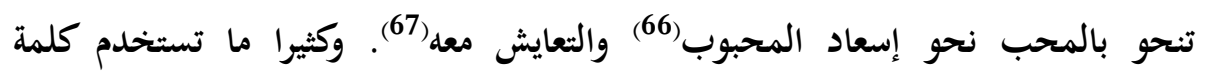
(المودة) في التعبير عن المحبة ويرى ابن القيم أن: "الود ...هو خالص الحب وألطفه

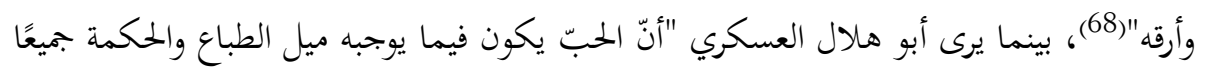

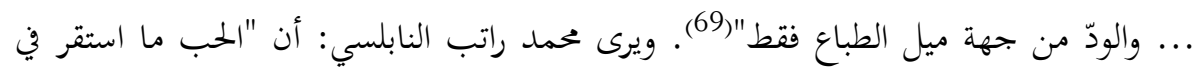

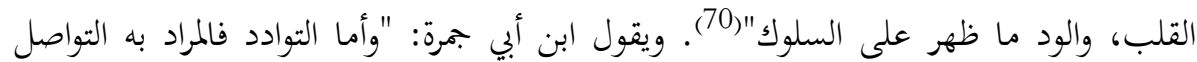

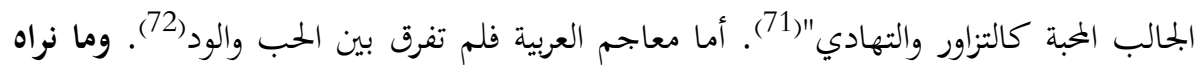
أن الحب أو المحبة والود أو المودة كلمات متقاربة في معانيها ولا يعنينا في بحثنا هنا حسم الخلاف بين معانيها؛ أما (التودد والتحبب) فهما فعلان يتحكم فيهما الإنسان، وقد الدود

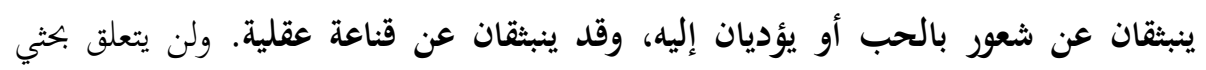
بالتحبب والتودد، وقد أفردت لذلك بحوثا أخرى (73).

وتجيز النصوص الإسلامية محبة الكافر المسالم لقرابة أو لفضل؛ فيقول تعالى لنبيه

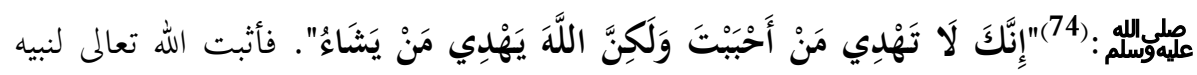

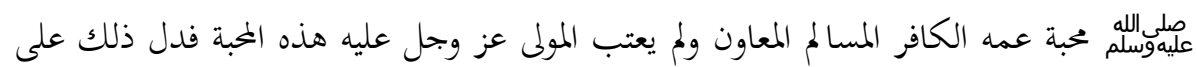

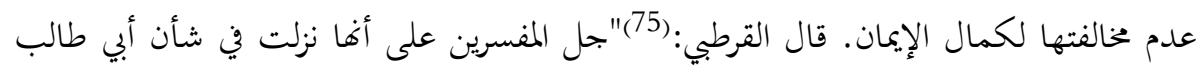

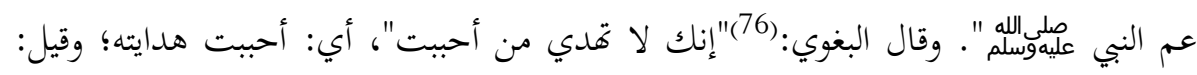

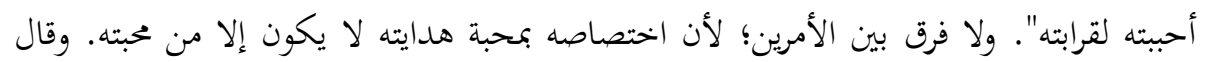

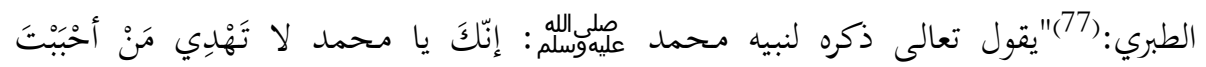

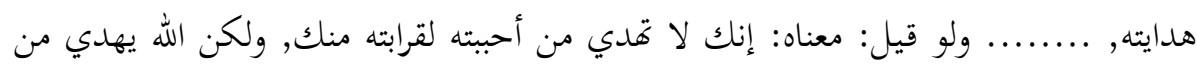


يشاء, كان مذهبا". وقال العثيمين:(78)"وهذا عام لأبي طالب وغيره، ويجوز أن يحبه محبة قرابة،

$$
\text { ولا ينافي هذا المحبة الشرعية". }
$$

ومما يدل كذلك على جواز محبة الكافر لا لكفره ولكن لشيء غير ذلك أن

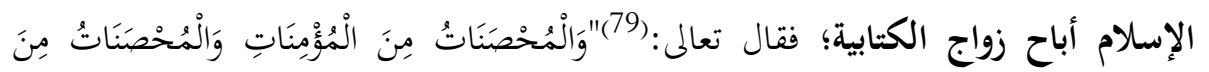

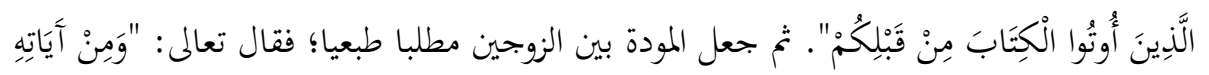

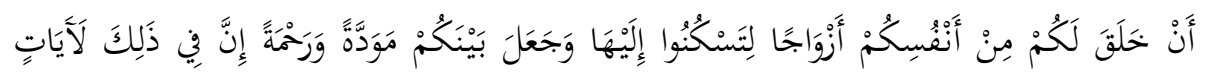

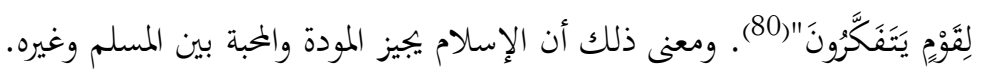

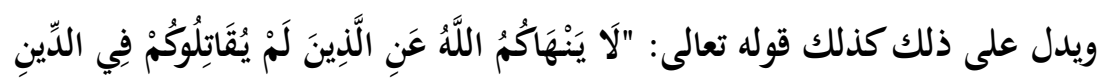

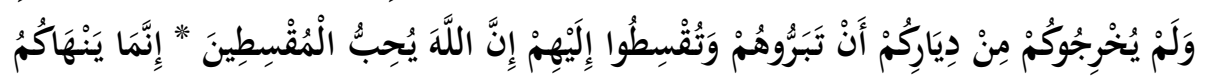

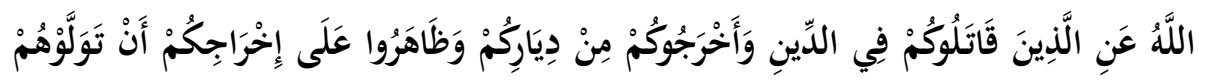

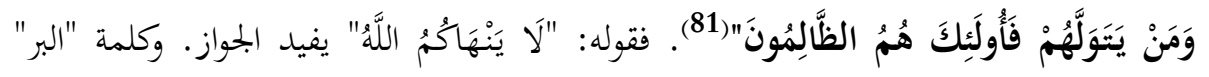

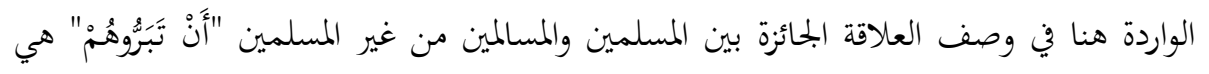
الكلمة المستخدمة في النصوص الإسلامية للوصف الواجب تحققه في أسمى علاقة بين إنسان

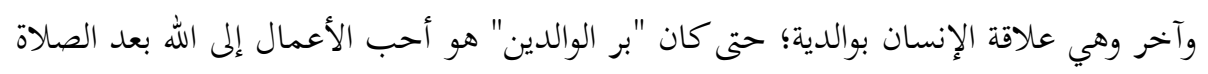

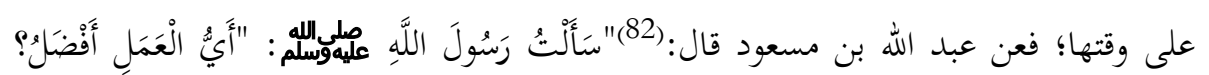

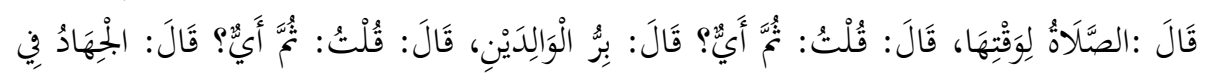

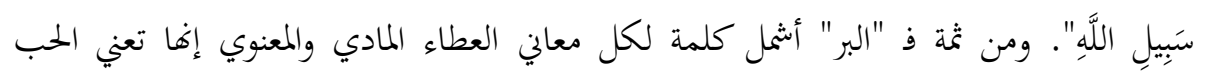
وزيادة.

وشرط هذه المحبة ألا تكون أشد من محبة الله ورسوله وجهاد في سبيله؛ يقول

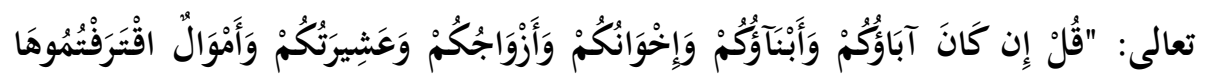

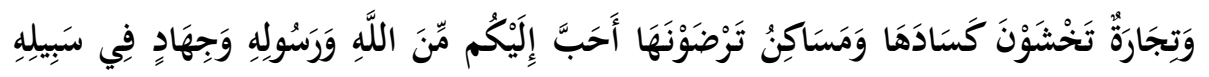

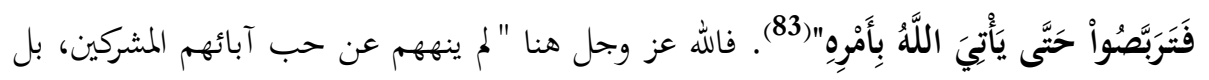

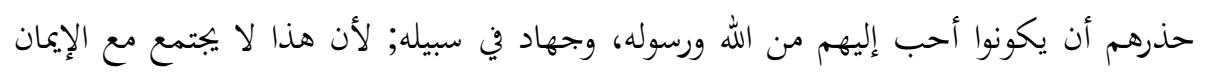

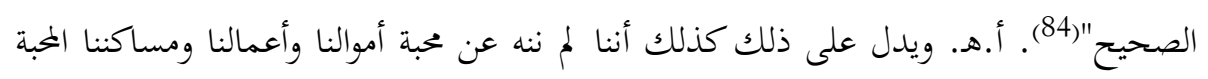
الطبعية، وإنما كان النهي عن كوغم أحب إلينا من الله ورسوله وجهاد في سبيله، والمعطوف أنه 
والمعطوف عليه لمما نفس الحكم. ومن ثمة فعندما دعت الدواعي للاختيار كان اختيار الصحابة لأحبب(85).

وهذه المحبة الجائزة يعسر التحرُز منها مع من يخالطهم المسلم بالقدر الواجب

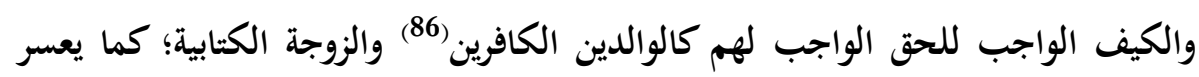

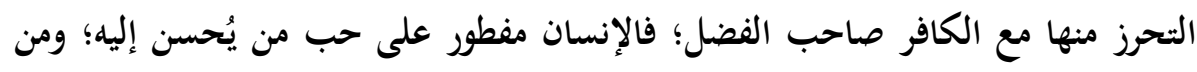

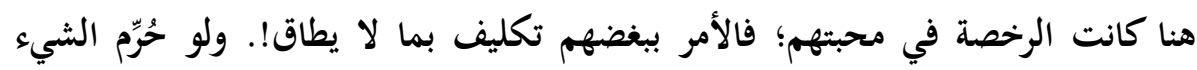
وأبيحت الوسائل الموصلة إليه لوقع الناس في حرج عظيم! (87.

ولم ينه الإسلام عن محبة الكافر لفضل أو لقرابة حتى وإن ناصب الإسلام

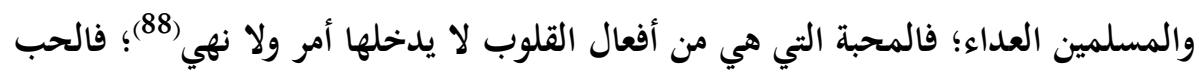

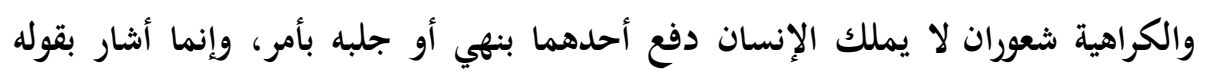

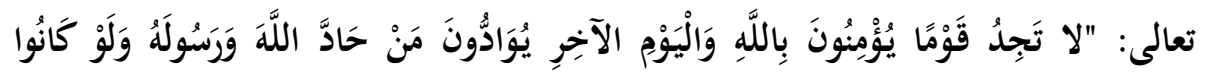

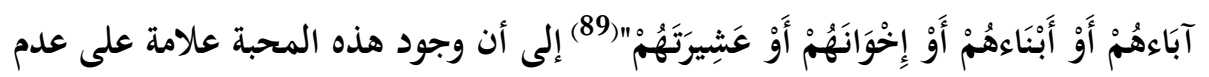

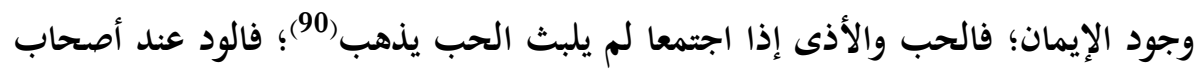

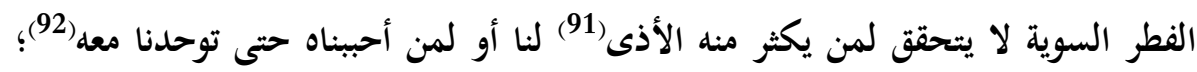

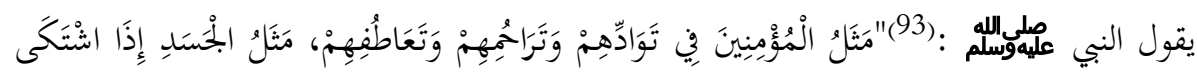

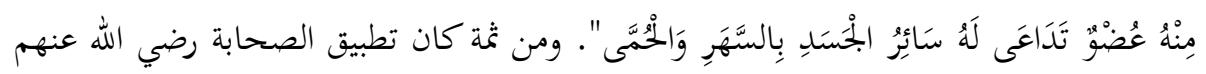

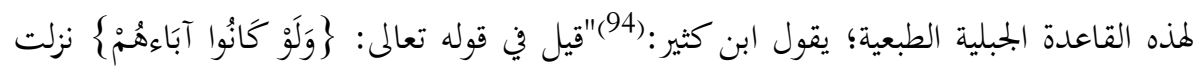

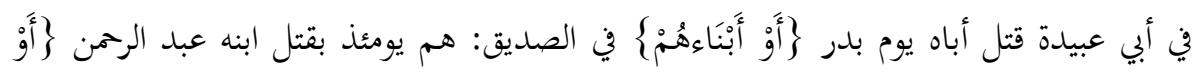

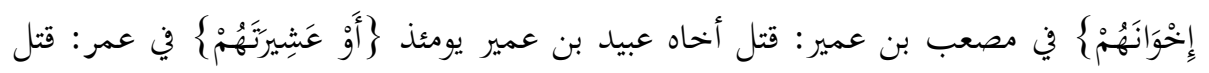

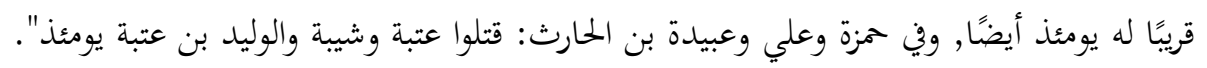

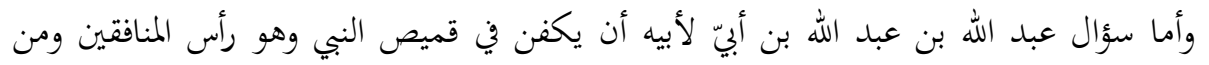

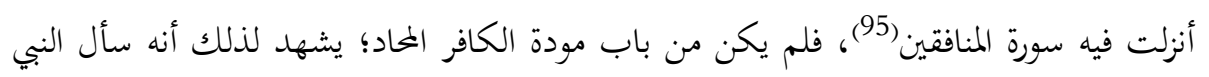

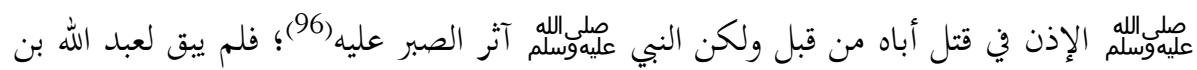

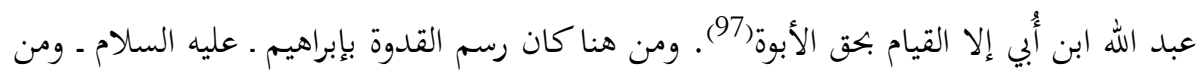

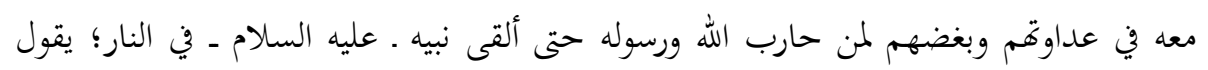




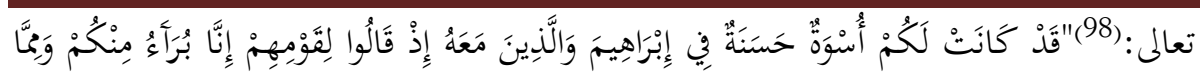

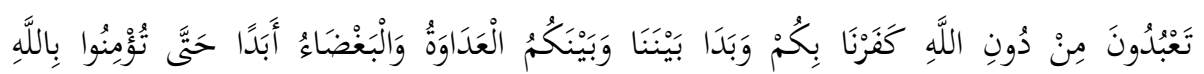

وحب الكافر المسالم (الجائز) لفضل أو لقرابة لا يمنع من بغض كفره (الواجب)

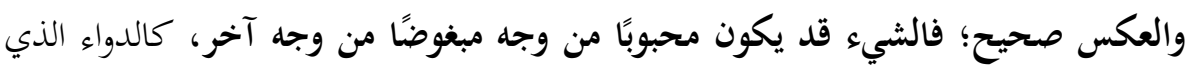

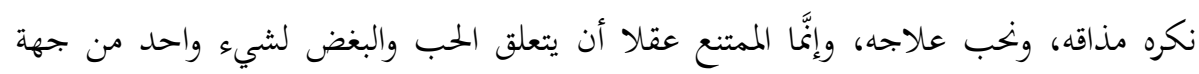

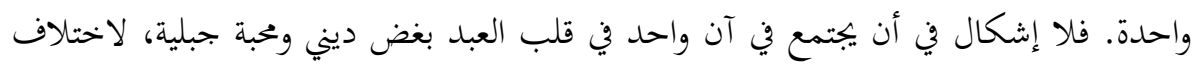

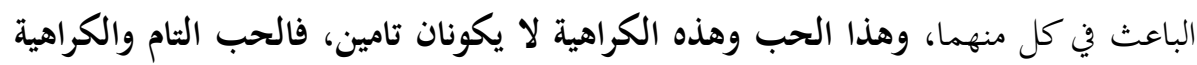

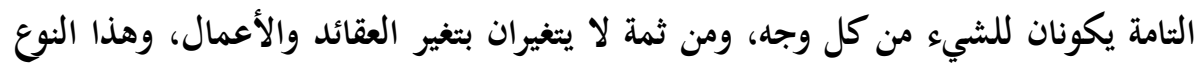
التام من الحب والكراهية لا تعرفه النصوص الإسلامية، وما تعرفه هو المحبة والكراهية المحددتان بسبب إذا زال زالتا. ومن هنا كان تفريق النصوص الإسلامية بين كراهية الفعل الإسله

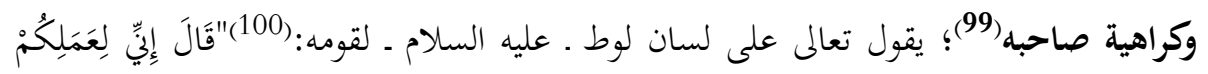

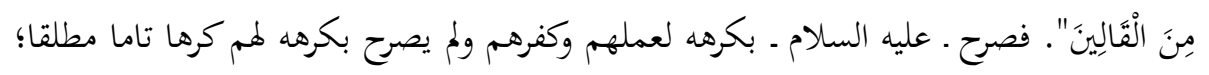

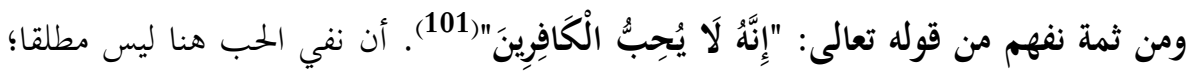

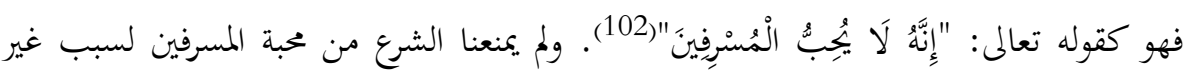

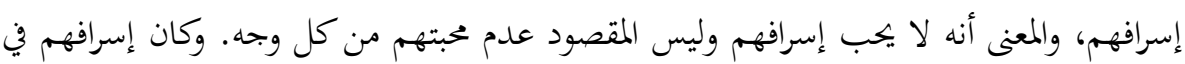

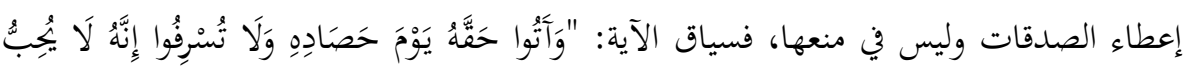

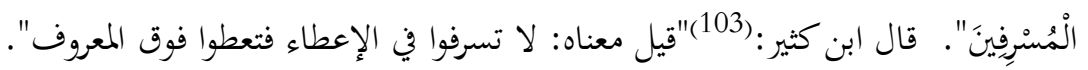

فإن كان حب المسلم للكافر لكفره وللفاسق لفسقه وللمبتدع لبدعته، فحقيقة المحبة هنا هي للكفر والفسق والبدعة، ومن هنا يتساوى محب الكفر مع الكافر، ومحب

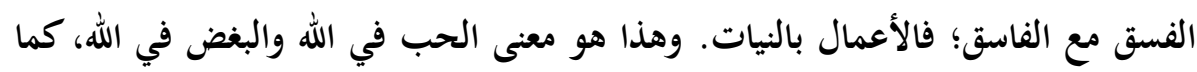

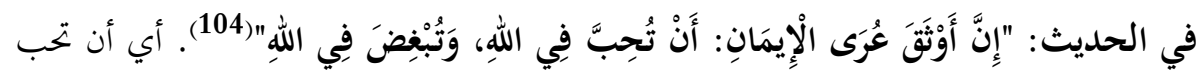

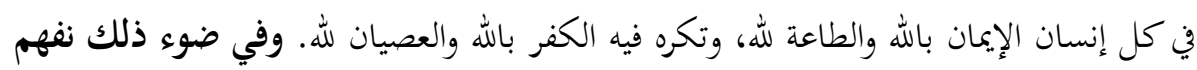

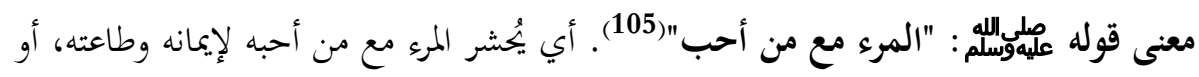

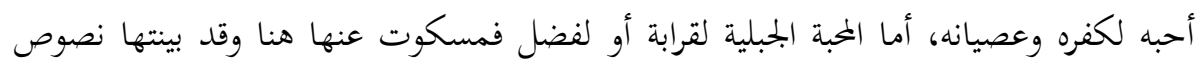


الباب. وسياق الحديث دال على ذلك: ففيه أن أعرابيا نادى رسول الله عليهولسلمه قائلا: "يا

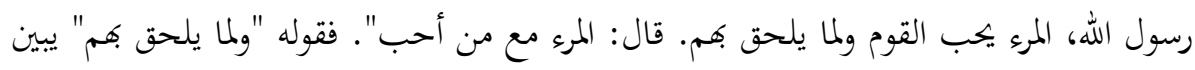

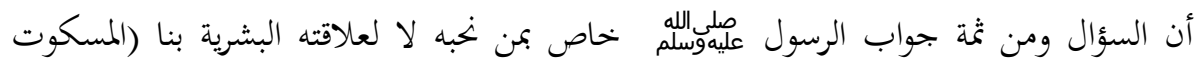

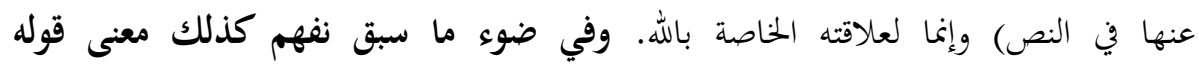

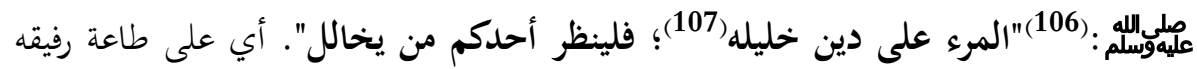

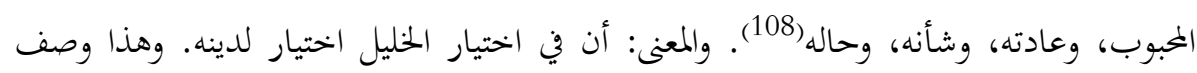

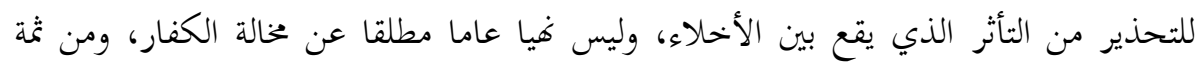

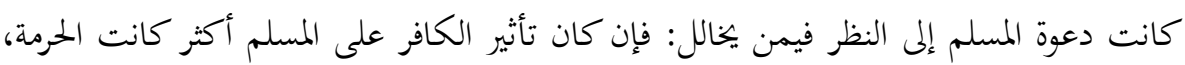

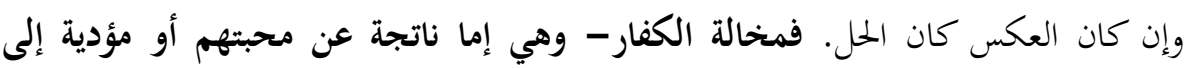

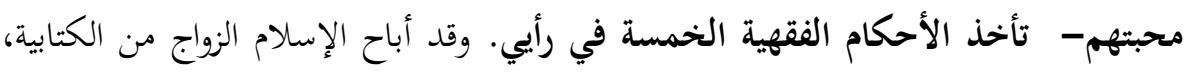

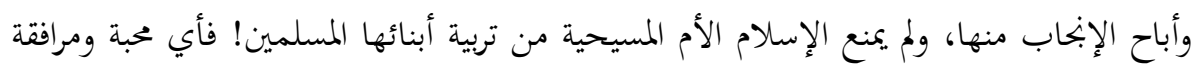

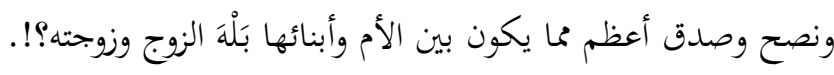

إلا أنه لو لم يُحب المسلمُ الكافرَ المسالم - القريب وصاحب الفضل- دون بغض له، وأعطاه حقه من المصاحبة الشرعية بالمعروف؛ فلا تثريب عليه. فمحبة هؤلاء جائزة، وليست بالواجبة ولا بالمستحبة، أما بغضهم ففيه نظر؛ وجواز محبتهم لا يعني جواز

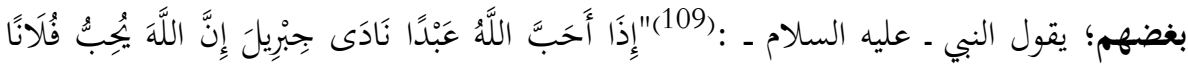

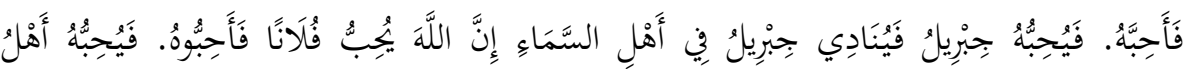

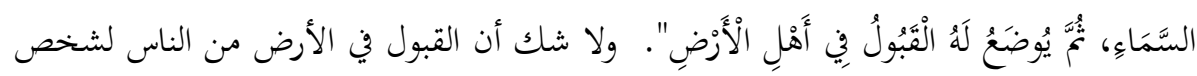

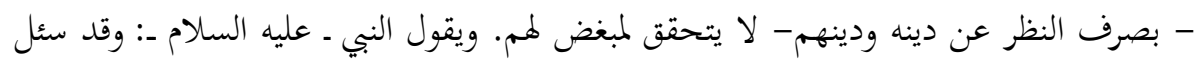

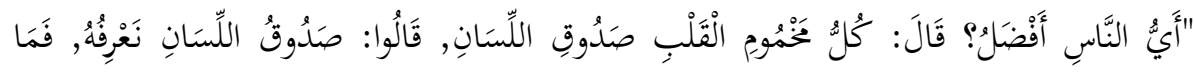

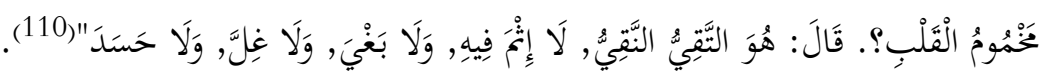

وإذا كانت الموالاة - المأمور بها- بين المؤمنين لا تنتفي بعداوة بعضهم بعضا

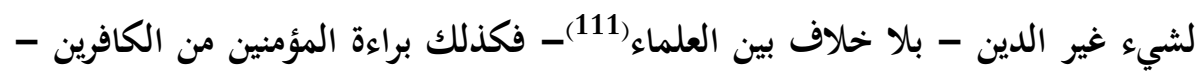

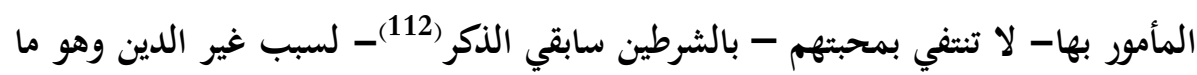
لم يتفق عليه العلماء(113). 
والنصوص الإسلامية تفرق بين "موالاة الكفار" المحرمة و"المحبة القلبية الطبعية

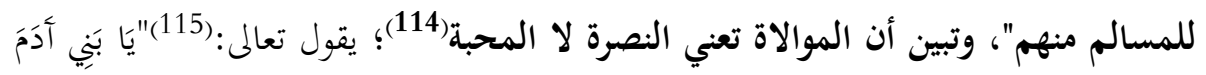

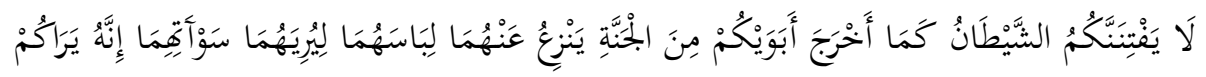

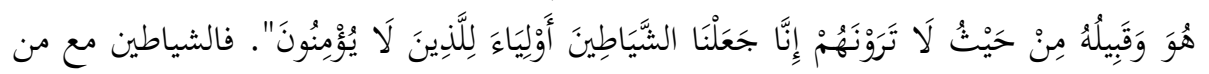

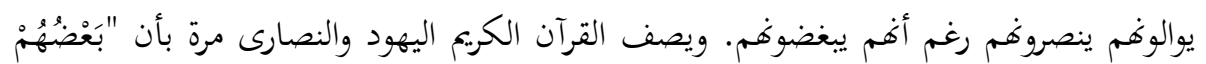

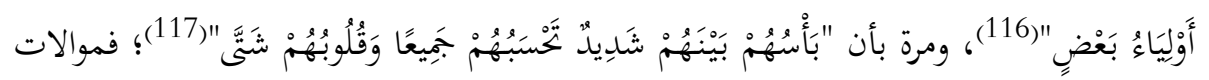
بعضهم لبعض مصحوبة ببغضهم بعضهم بعضا؛ ومن ثمة يتعين أن المقصود بالموالاة هو "النصرة"

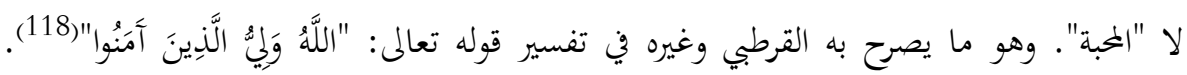

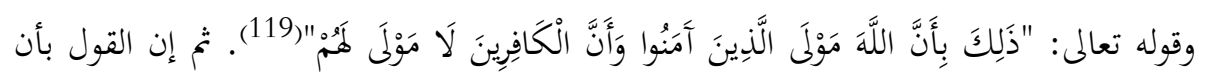

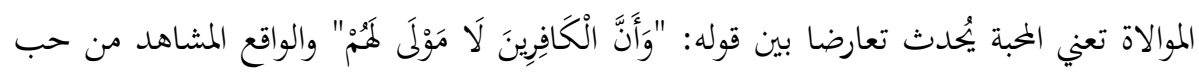
الكفار بعضهم بعضا.

\section{وتجعل النصوص الإسلامية لموالاة الكفار أحكاما عدة:}

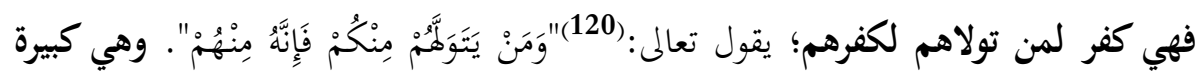

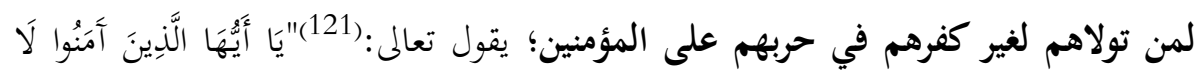

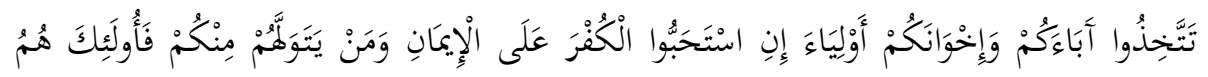

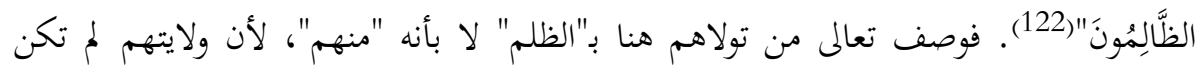

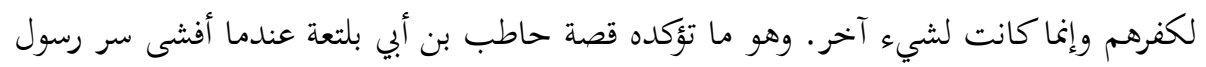
الله ـ عليه السلام ـ لقريش (123).

وهي مباحة من باب التعاون على العدو المشترك؛ وهو ما يبينه دستور دولة المدينة

الذي ينص على حق التناصح والتناصر بين المسلمين واليهود (124).

وهي واجبة لمناصرة الضعيف بدرجات مختلفة من الوجوب بحسب القدرة، وبحسب

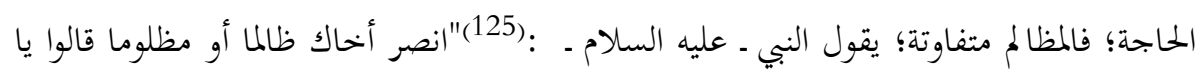

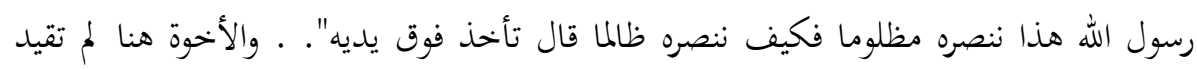

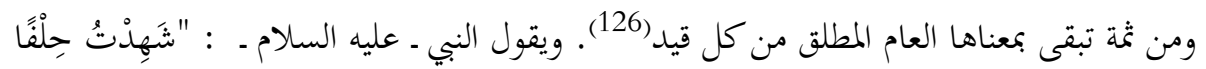




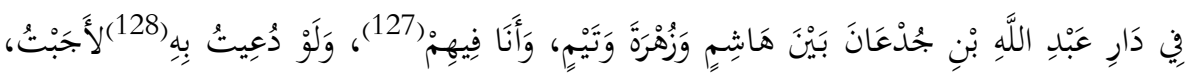

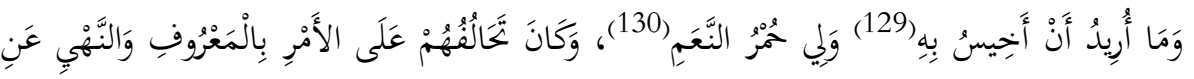

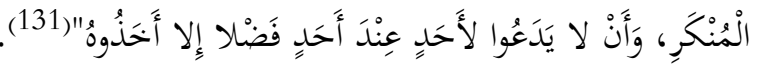

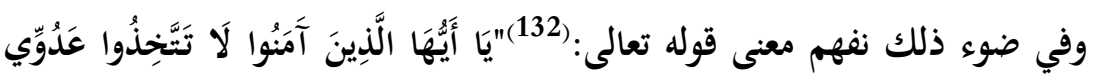

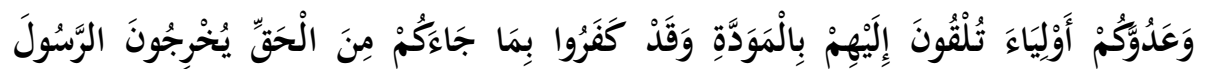

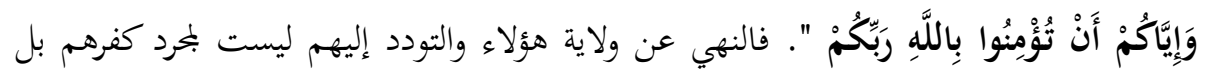

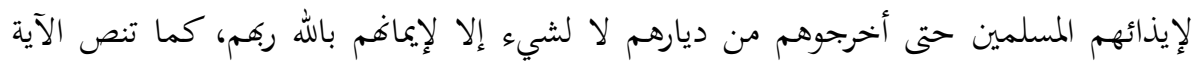

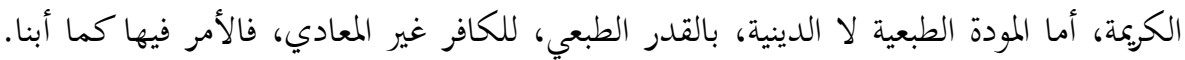

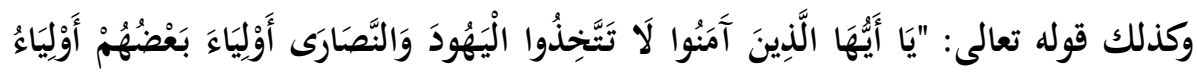

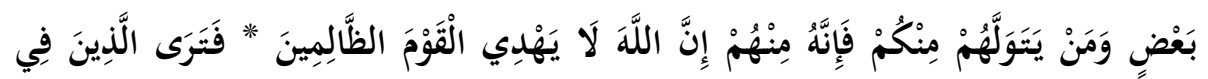

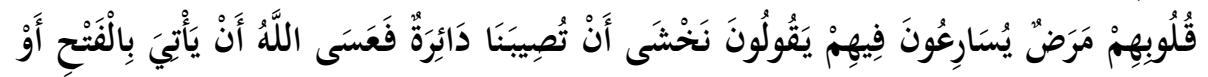

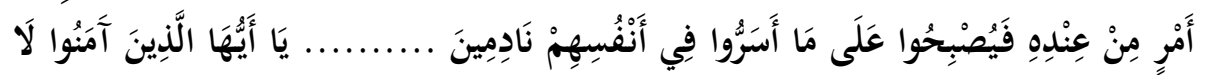

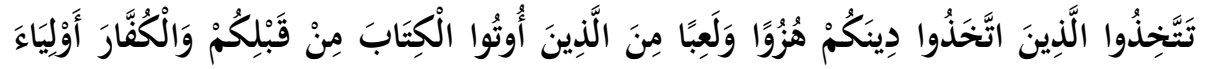

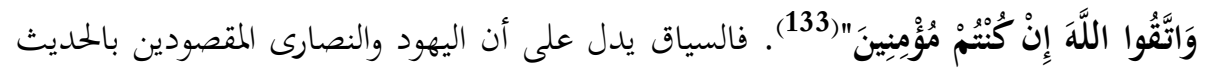

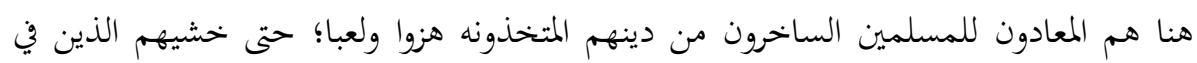
قلوبهم مرض فسارعوا فيهم؛ فالنهي عن ولاية هؤلاء ليست بلمرد كفرهم بل للإيذائهم المسلمين (134).

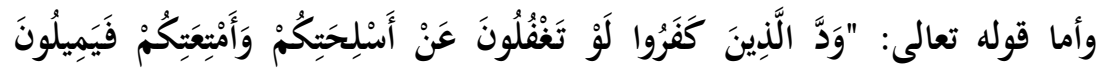

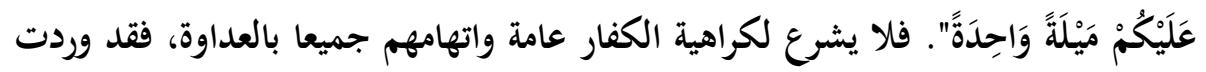
الآيتان في معرض الحديث عن الاستعداد للقتال، فهما تتحدثان عمن يقاتلنا منهم لا عنهم جميعا؛ ومن ثمة أعطت الآيتان أحكاما خاصة للصلاة عند مواجهة هؤلاء، ولو كانت

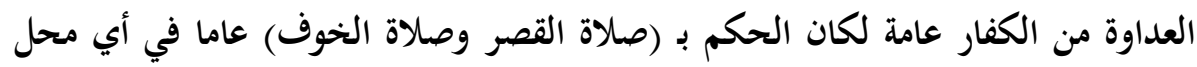

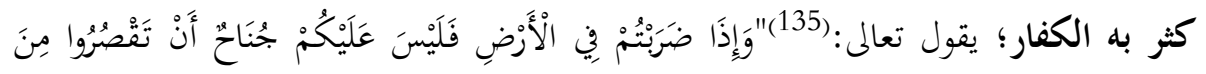

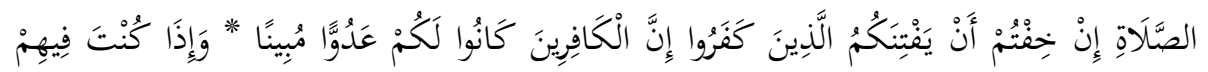

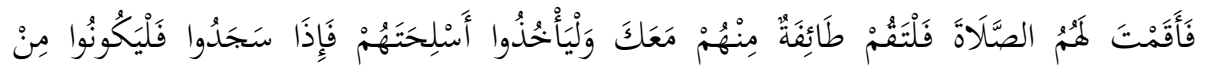




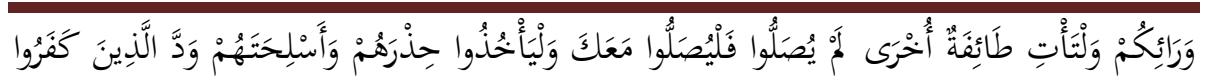

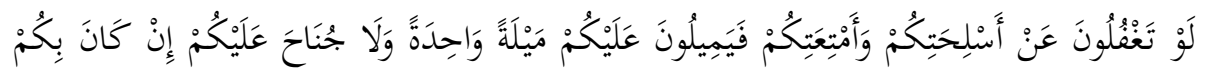

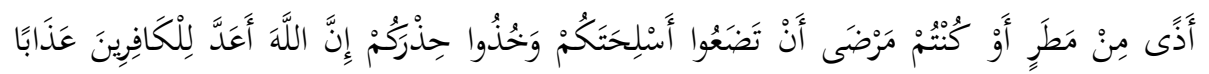

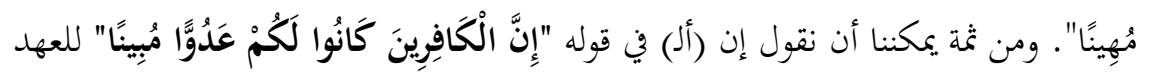

لا للجنس.

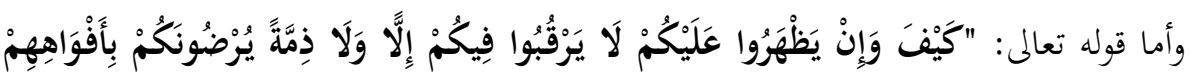

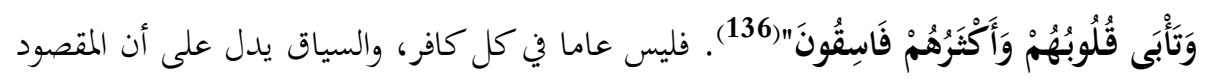

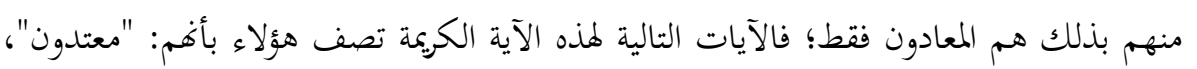

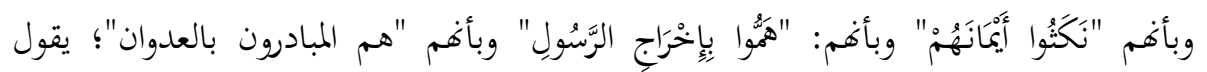

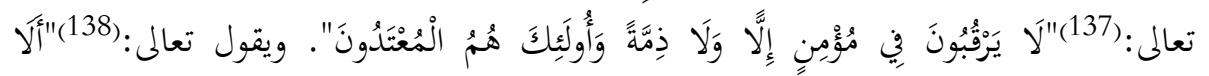

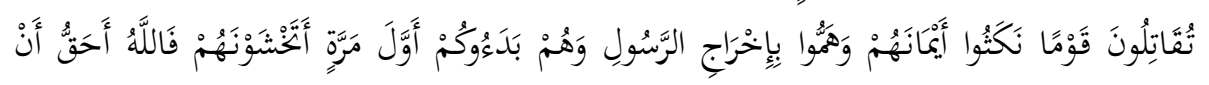

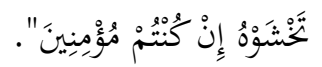

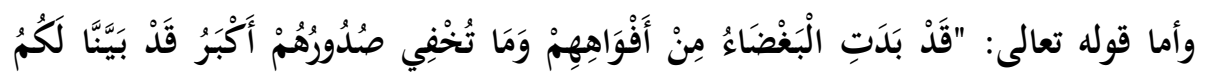

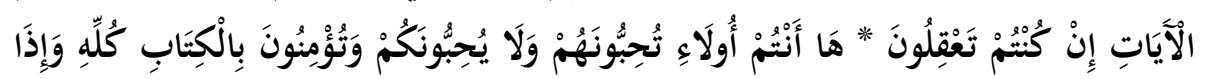

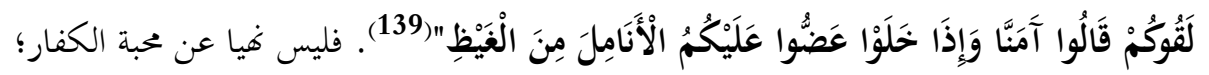

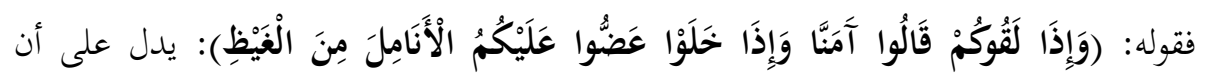

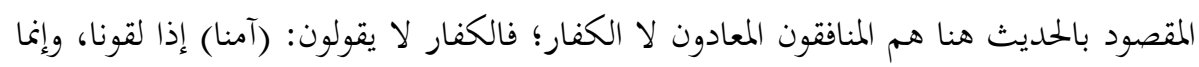
المنافقون هم من يفعلون ذلك.

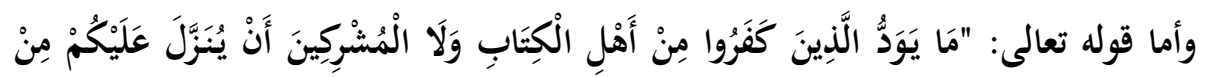

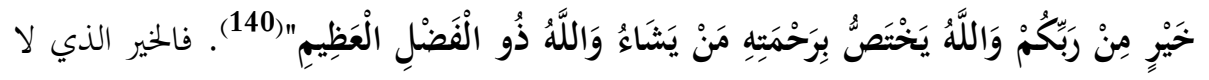

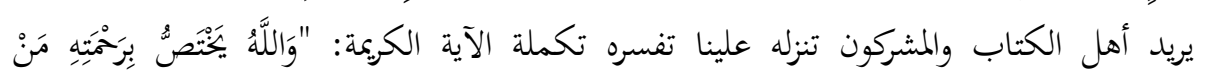

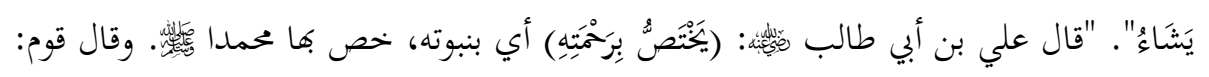

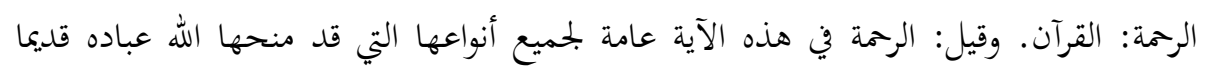

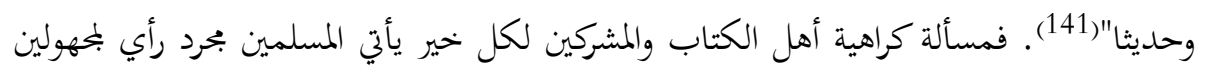


من آراء ثلاثة مذكورة في تفسير الآية. وقال الطبري:(142)"(ما يَوَدّ) ما يحبّ, أي ليس يحبّ كثير

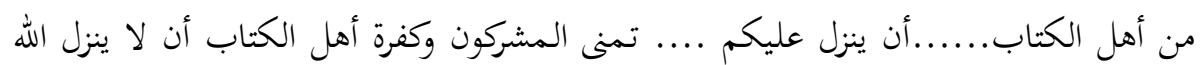

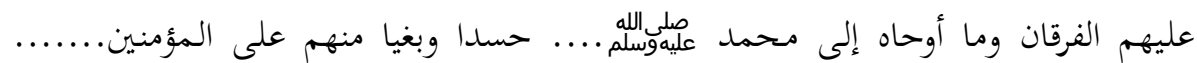

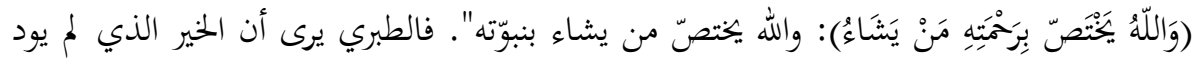

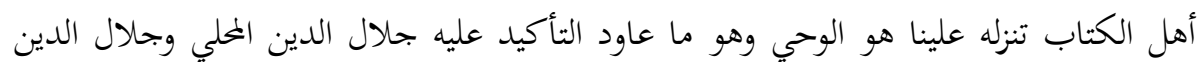
السيوطي في تفسيرها(143) ويضيف الطبري فائدة بالترفع عن التعميم في قوله "ليس يحبّ كثير من أهل الكتاب". وهو ما يتوافق مع المشهود كحب المرأة غير المسلمة لأولادها المسلمين.

وانطلاقا من كل ما سبق كانت دعوة الإمام علي لمحبة الناس أجمعين: مؤمنهم وكافرهم، حين

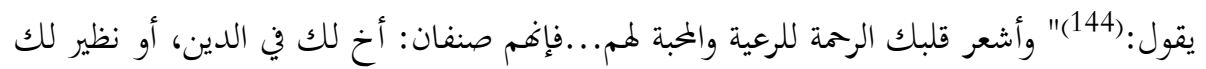
في الخلق " 
الخحاتمة

خلاصة واستخلاص

الخلاصة:

بعد هذه القراءة في الكتب المقدسة لدى أصحابها: اليهودية والمسيحية والإسلامية، نخلص بالآتي:

التلمود:

لم يمكننا الوقوف على مفهوم محدد للحب في التلمود انطلاقا من لغته (العبرية).

رغم أن لفظة الحب مستخدمة في التلمود إلا أني لم أعثر لها فيه على مفهوم محدد وتركت المسألة لاجتهادات الحاخامات.

لعل من أهم وأشمل تعريفات الحاخامات للحب تعريف الحاخام ستينسالتز. لم أعثر في التلمود سوى على نص واحد يأمر بمحبة الحلق أجمعين بصرف النظر عن انتمائهم الديني وفي الاتحاه المقابل بند نصوصا كثيرة في التلمود تناقض عمليا محبة مخالف الملة. العهد القديم: لم يمكننا الوقوف على مفهوم محدد للحب في العهد القديم انطلاقا من لغته (العبرية). رغم أن لفظة الحب مستخدمة في العهد القديم إلا أني لم أعثر لها فيه على مفهوم محدد. 
يفسح العهد القديم مكانا لمحبة الناس جميعا بصرف النظر عن دينهم: فينفر من الحقد والحسد والكراهية؛ وينهى عن كراهية المخالف في المعتقد.

يحث العهد القديم على محبة المخالف في المعتقد بل ويُغري بها.

يرسم العهد القديم القدوة بالرب تعالى في محبة مخالف المللة، معلال لها، ويأمر المؤمنين بما، معللا أمره لهم.

وفي الابحاه المقابل بند نصوصا كثيرة في العهد القديم تناقض عمليا محبة مخالف الملة.

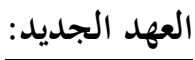

لم يمكننا الوقوف على مفهوم محدد للحب في العهد الجديد انطلاقا من لغته الأصلية (الآرامية)، وعوضا عن ذلك كانت نصوص العهد الجديد واضحة الدلالة على مفهوم الحب في المسيحية.

المحبة في مفهوم النصوص المسيحية المقدسة هي سلوك عملي أولا وأخيرا؛ وهذا السلوك العملي

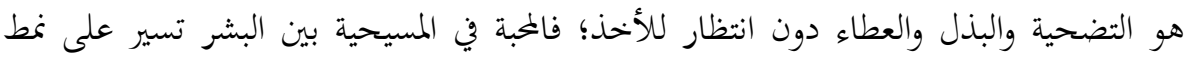
حب الله للبشر كما عبر عنه العهد الجديد.

يقسم العهد الجحديد المحبة إلى قسمين متلازمين: محبة الله ومحبة الناس. ومحبة الناس تتسع في العهد الجديد حتى للكافر، ويرسم العهد الجلديد القدوة لما ويأمر بها.

يعلي العهد الجديد من شأن المحبة؛ فيجعلها غاية الوصية، ويجعل من محبة الناس جميعا بصرف النظر عن دينهم

الوصية الثانية بعد محبة الله تعالى، بل يصرح العهد الجديد بأن الشريعة تدور كلها حول هاتين

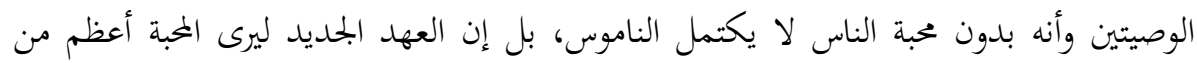

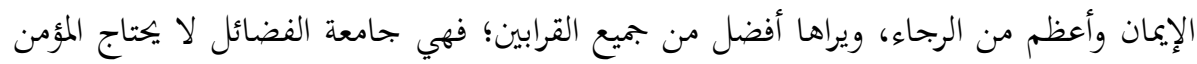

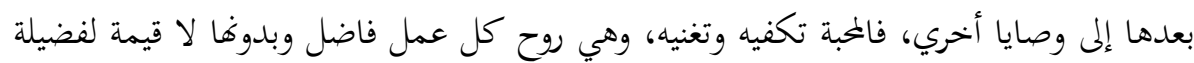

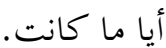


ويفسح العهد الجديد مكانا للمحبة؛ فينفر من الكراهية حتى اعتبرها كالقتل؛ فهي في منظوره قتل قلبي ومقدمة للقتل الواقعي؛ ومن هنا فهو لا ييعد عنه كثيرا في الإثم.

\section{النصوص الإسلامية:}

1. الحب ومرادفاته بيّن المعنى واضح الدلالة في لغة الإسلام (العربية) ولم تتجاوز

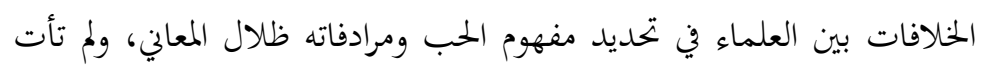
النصوص الإسلامية المقدسة بمعاني اصطلاحية للحب ومرادفاته مخالفة للمعانى

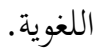

2. بالنظر في معاني مادة (ح ب ب) في لغة الوحي الإسلامي (العربية) يمكن

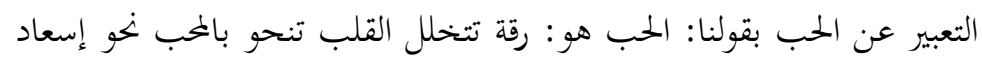
المحبوب والتعايش معه. وكثيرا ما تستخدم كلمة (المودة) في التعبير عن المحبة،

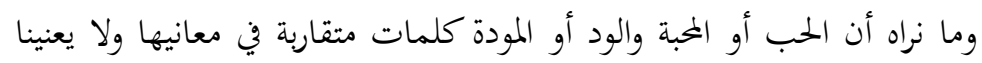

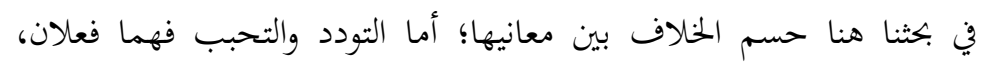

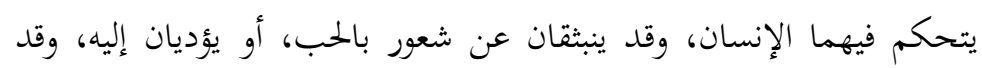
ينبثان عن قناعة عقلية. ولا تعلق لبحثنا بكما.

3. تجيز النصوص الإسلامية محبة الكافر المسالم لقرابة أو لفضل، وشرط هذه المحبة ألا تكون أشد من محبة الله ورسوله؛ وذلك أن هذه المحبة الجائزة يعسر التحرُّز

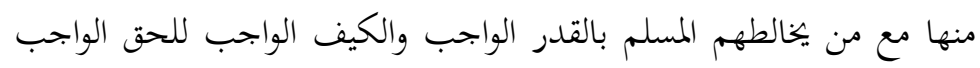

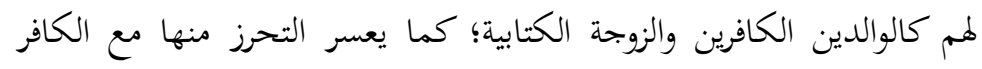
صاحب الفضل؛ فالإنسان مفطور على حب من يُمسن إليه؛ ومن هنا كانت

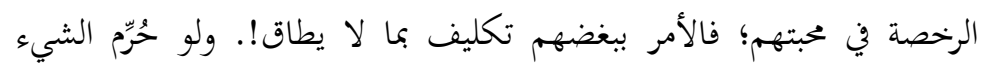

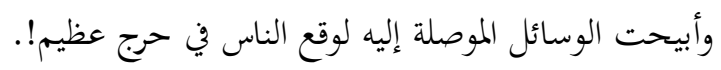


4- لم ينه الإسلام عن محبة الكافر لفضل أو لقرابة حتى وإن ناصب الإسلام والمسلمين العداء؛

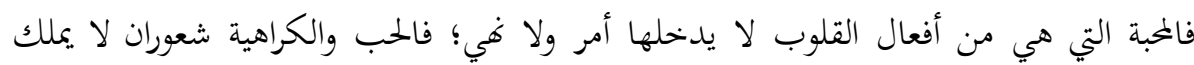

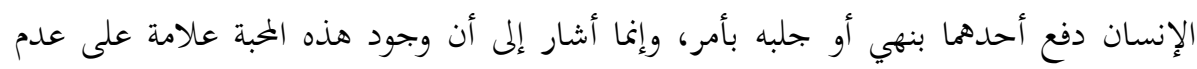

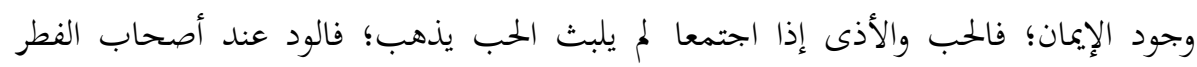

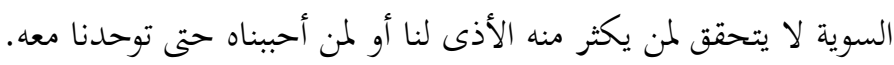

5-حب الكافر المسالم (الجائز) لفضل أو لقرابة لا يمنع من بغض كفره (الواجب) والعكس

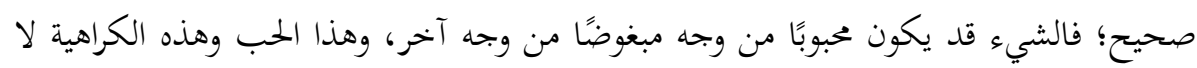

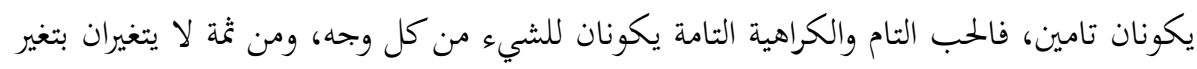
العقائد والأعمال، وهذا النوع التام من الحب والكراهية لا تعرفه النصوص الإسلامية، وما تعرفه هو المخبة والكراهية المحددتان بسبب إذا زال زالتا.

6-إن كان حب المسلم للكافر لكفره وللفاسق لفسقه وللمبتدع لبدعته، فحقيقة المحبة هنا هي

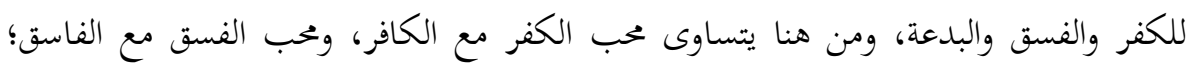
فالأعمال بالنيات.

7-لو لم يُجب المسلمُ الكافرَ المسالم - القريب وصاحب الفضل- دون بغض له، وأعطاه حقه

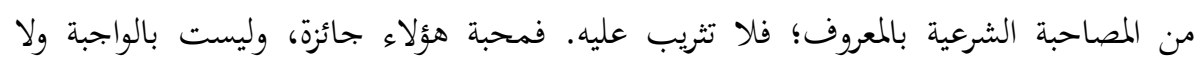

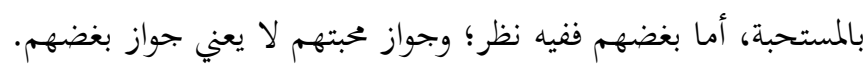

8-كما أن موالاة المؤمنين لا تنتفي بعداوتهم، فكذلك براءة المؤمنين من الكافرين لا تنتفي بمحبتهم لسبب غير كفرهم وفسقهم. 9-تفرق النصوص الإسلامية بين "موالاة الكفار" المحرمة، و"الحبة القلبية الطبعية للمسالم منهم"، وتبين أن الموالاة تعني النصرة لا المحبة. 10-بتعل النصوص الإسلامية لموالاة الكفار أحكاما تتدرج من الكفر وحتى الوجوب. استخلاص:

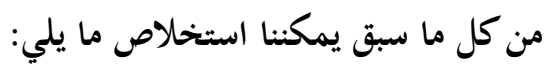


- إن الولاء للإخوة الإنسانية وما ينشأ عنه من أخلاق إنسانية رفيعة أمر ظاهر ومؤكَّد في الكتب المقدسة محل هذه الدراسة.

- حث التلمود مرة على محبة مخالف الملة، وحث مرات على ما يناقض تلك المحبة. حث

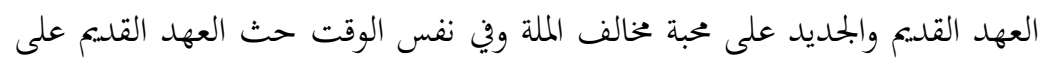

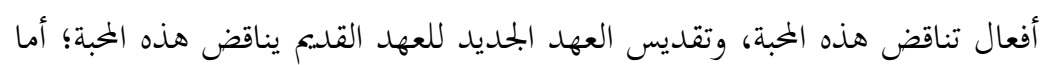
النصوص الإسلامية فأجازت محبة مخالف الملة ولم تحث عليها ولم تناقضها. - إن التوقف أمام تلك النصوص المقدسة التي بندها أحيانا تغري بالإساءة إلى الآخر في

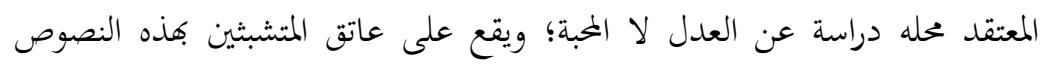
عبء توجيه ما أوردناه من نصوص تحض على المحبة لمخالف الملة. - عندما حث العهد القديم على محبة غخالف الملة كثيرا ما وصفه بـ "الغريب". وعندما

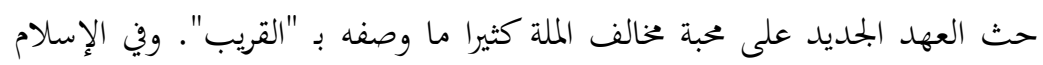

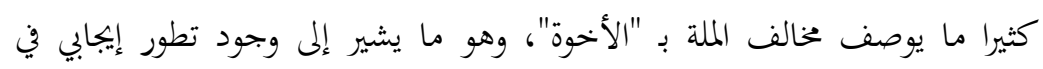

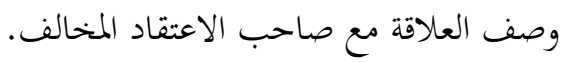

- - إن المواقف الداعية لكراهية مخالف الملة لا تنطلق من عامة النصوص المقدسة في أي

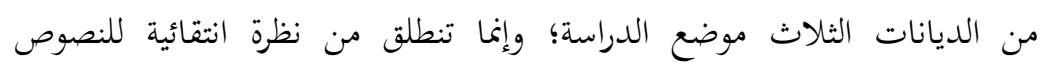
وتفسيراما. ولقد ساهمت طبيعة النص اليهودي والمسيحي المقدس في إزكاء هذه تلفهات

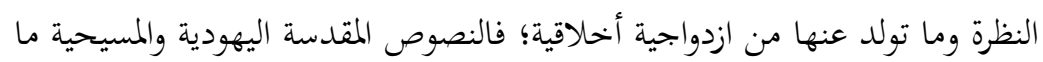

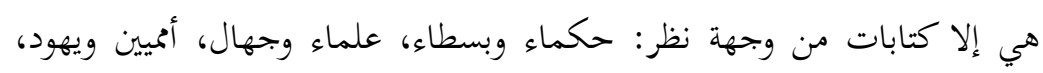

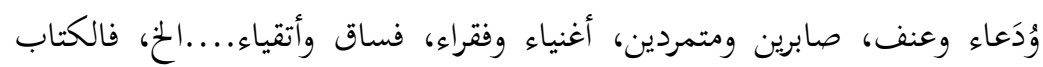

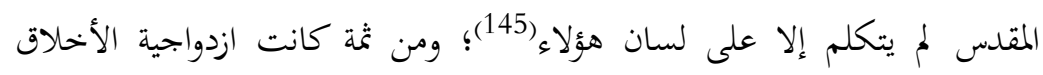

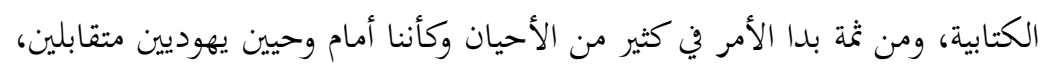
ووحيين مسيحيين متقابلين لإلهين مختلفين، أحدهما إله للمثالية الأخحاقية والآخر للعدوانية! 
فالتلمود لم أعثر فيه سوى على نص واحد يحث على محبة مخالف الملة بين ركام من النصوص العدائية!.

والعهد القديم الذي حث وألح في حثه على محبة خخالف الملة مليء بالنصوص العدائية التي تناقض هذه المحبة!

والعهد الجديد الذي قدس محبة مخالف الملة قدس في ذات الوقت العهد القديم بنصوصه العدائية!(146). (العهد الجلد.

ورغم أنه لا يوجد نص إسلامي عن الله تعالى أو عن رسوله عليلوقلالمه صحيح صريح يضاد محبة

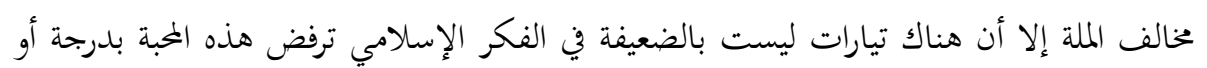
بأخرى. ولعله من أهم الأخطاء العلمية التي وقع فيها أصحاب هذه التيارات ما يلي: الأخذ بظاهر النصوص، وإغفال القواعد الأصولية في الفهم. عدم التفريق في الحكم بين الفعل وفاعله. الخلط بين جواز الشيء وجواز نقيضه. الخلط بين ما يدخله الأمر والنهي، وما يعتبر وجوده علامة على وجود منهي عنه. الانطلاق من مسلمات غير مسلم بها عند غيرهم من العلماء. التمسك بخيارات لغوية دون شفيع، وفي اللغة متسع لغيرها. تعميم الأحكام في قضايا الأعيان. التعميم بلا مسوغ. القياس الفاسد. 


$$
\begin{aligned}
& \text { الفهم المتعارض مع سياق النص. } \\
& \text { الفهم المتعارض مع أسباب النزول. } \\
& \text { الخلط بين العام والخاص. } \\
& \text { النظرة غير الشاملة للنصوص. }
\end{aligned}
$$

التخير من مواقف السلف وأقوالهم ما يشفع لآرائهم والسكوت عما لا يشفع؛ ثم زعم المتابعة لفهم السلف، والاحتجاج لتقليدهم بأن القدماء أقدر على فهم مراد الله ومراد رسوله عليهولسلم ونسوا أو تناسوا الإطار السياسي والاجتماعي الذي صدرت فيه فتاوى القدماء، وبفرض تشابه الظروف، بل وتماثل الأحوال، فلا تلازم بين الفضل وعظم الشأن وبين جعل الواحد من السلف الكرام مشرِّعا كالرسول عليهوسلم وقد ختمت النبوة، وختمت العصمة؛ وما ورد من نصوص تأمر بالاقتداء ببعض الصحابة فتحمل على الاقتداء بهم في الفضل ويف اتباع الدليل، لا

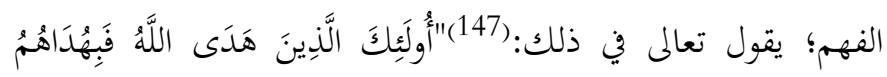

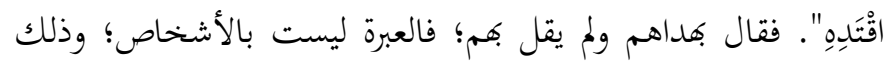

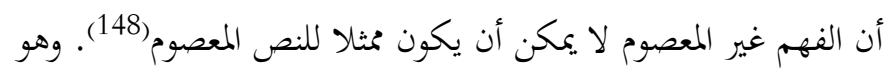

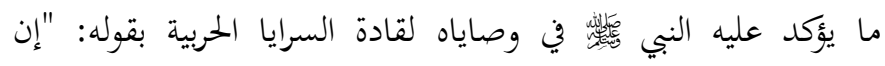
حاصرت أهل حصن فأرادوك أن تنزهم على حكم الله؛ فلا تنزهم على حكم الله، ولكن أنزهم على حكمك (149)؛ فإنك لا تدري أتصيب حكم الله فيهم أم لا"(150). بل إن السلف قد غوا عن التسليم لفهمهم

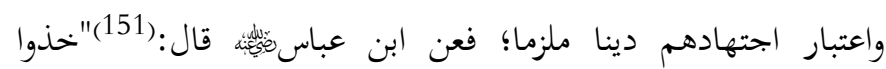
الحلكمة ممن سمعتموها؛ فإنه قد يقول الحلكم غير الحكيم، وتكون الرمية

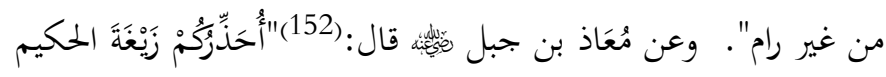
فإن الشيطان قد يقول كلمة الضلالة على لسان الحكيم؛ وقد يقول

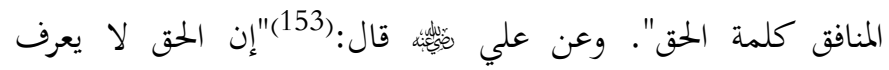


بالرجال، اعرف الحق تعرف أهله". وعن ابن عمر - رضي الله عنهما-

$$
\text { رفعه: "خذ الحكمة ولا يضرك من أي وعاء خرجت"(154). }
$$

- تتميز النصوص الإسلامية في موضوعنا هذا بوفرة غير معهودة في الكتب المقدسة الأخرى موضع الدراسة، كما امتازت بجهد فقهي غير مسبوق في تاريخ الأديان الأخرى(155)؛ فطول وقوفنا أمامها مقارنة بوقوفنا أمام نصوص الأديان الأخرى ليس لهري تقصيرا في حق الثانية، وإنما اقتضت طبيعة الأمر ذلك.

- إنه لمن الصعوبة بمكان الحديث عن ترتيب للأديان في درجات المحبة لمخالف الملة، وذلك لأن هذا الحديث يتطلب أمورا عديدة لا يمكن اعتبارها بحتمعة في المقارنة

عدد النصوص المعارضة لمذه المحبة.

درجة صحة النصوص المعارضة.

مدى وجاهة توجيه النصوص المعارضة.

عدد النصوص المؤيدة لمحبة مخالف الملة(156).

درجة صحة النصوص المؤيدة.

درجة التأكيد في كل نص على محبة مخالف الملة

درجة التأكيد في كل نص على أنه يشمل غير المؤمنين، فكثيرا ما يتم التأكيد على المحبة دون تأكيد على شمولية ذلك لمخالف الملة.

نوع التأكيد، هل هو تأكيد نابع من الاهتمام بهذا الوجه، أم تأكيد نابع من إنكار المدعويين له، بمعنى أن بعض الأديان قد يؤكد على محبة مخالف الملة بسبب معارضة المدعويين، لا بسبب العناية

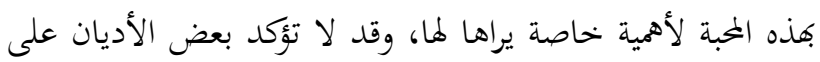


هذه المحبة لتحلي المدعويين بها أو لأفم لا يعارضوفا، ومن هنا لا

يمكن اعتبار التأكيد أو عدمه ميزة لدين على دين. 


\section{التوصيات}

على المسؤلين عن التعليم: إعادة النظر في مناهجنا التعليمية لترسيخ الوجه المشرق للأديان في علاقتها مع الآخر، وتنقيته من كل شبهة فاسدة.

على كل صاحب قلم أو سلطة: تحري الحق والحقيقة، والحذر من النظر إلى

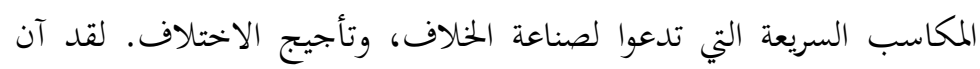
الأوان للتخلي عن مبدأ أن (الأخبار السيئة هي وحدها الأخبار الجيدة) فلا شيء يفسد نظامنا الأخلاقي مثل هذا المبدأ الإعلامي! على الوعاظ والأدباء: عدم الاكتفاء بما يقوم به الدارسون من مخاطبة العقل في حديث التعايش، فالمتعايش في حاجة إلى قلب مفكر وفهم محب! إن الدراسات العلمية الحديثة تبين أن اللاوعي هو المتحكم الأكبر في سلوكياتنا مع الآخر.

أسأل الله تعالى أن يبعلنا ممن يستمعون القول فيتبعون أحسنه د/ جمال الحسيني أبوفرحة 


\section{الهوامش}

1. منها: البحث عن هوية، وتقوية الهوية، واستثارة الذات للعمل من أجل النهضة، بل والتسلية:

فأما البحث عن الهوية: فيقول فيه صامويل هنتنجتون: "بالنسبة للشعوب الباحثة عن هوية...... فإن العدو

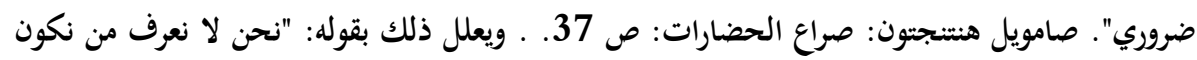
إلا عندما نعرف (من ليس نحن)، وذلك يتم غالبا عندما نعرف (نحن ضد من)". السابق، ص صرون 39. وأما تقوية الهوية: فيقول عنه إنجمار كارلسون: "لقد أصبح استمرار [فكرة الخطر الخارجي الشامل] ....

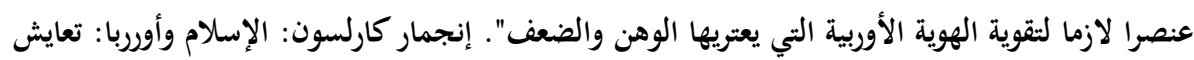

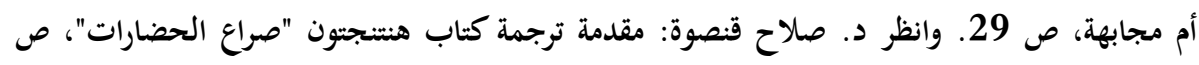
27 . . ويقول ديبون على لسان أحد شخوص روايته البحيرة الميتة: "إن لم نكره ما ليس نحن، فلن يمكننا أن نحب ما هو نحن". صامويل هنتنجتون: السابق، ص 236.

وأما استثارة الذات للعمل من أجل النهضة: فذاك لأن مشاعر الكراهية تعلو وتحجب الشعور بالتعب

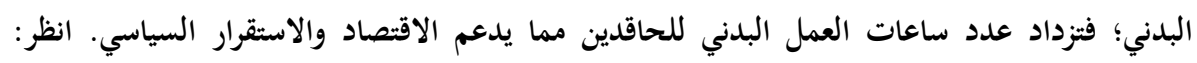

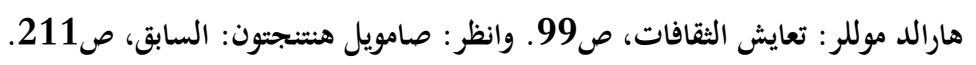

وأما التسلية: فيشير إليها فرانسيس فوكوياما في تعليقه على ما انتهى إليه في أطروحته المعنونة بـ "نهاية

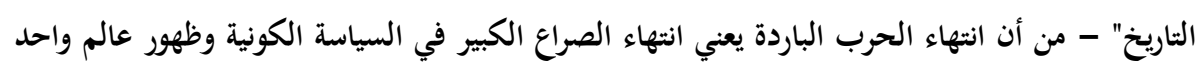

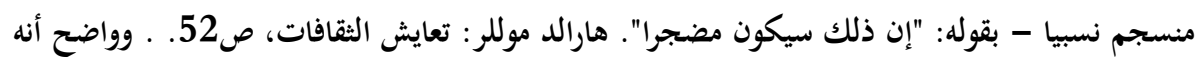

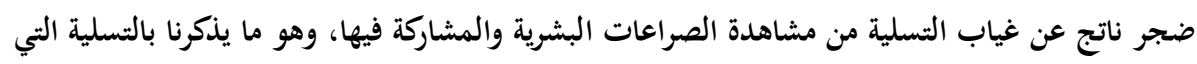
يشعر بها مشاهدو مصارعة الديكة ومشاهدو مصارعة الثيران والمشاركون فيها، وكأن قيمة الإنسان في مئي عيون هؤلاء كقيمة ثور أو قيمة ديك!

2. حيث أدرك فريق من السياسيين: حكاما ومعارضين، أن من وسائل السيطرة السياسية وجود شيطان سياسي يتم البحث عنه أو صناعته. حتى إذا لم يجد الحديث عن الولاء السياسي مبررا لوجوده من عمل مخلص جاد ينهض بالأمة كان العداء للشيطان - حقيقيا كان أو مصنوعا-

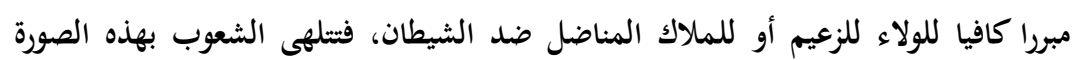

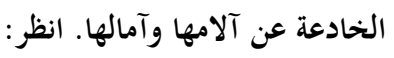




$$
\text { هارالد موللر : السابق، ص } 96 .
$$

روايتا أورويل: (George Orwell: Animal Farm- Nineteen Eighty Four).

فالعامة والغوغاء تستهويها فكرة الشياطين المرجومة التي ينزلون عليها غضبهم، فالناس في حاجة إلى

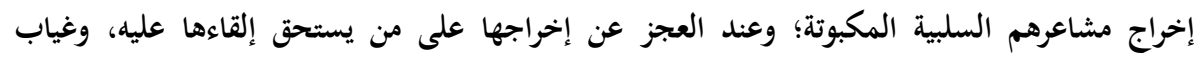

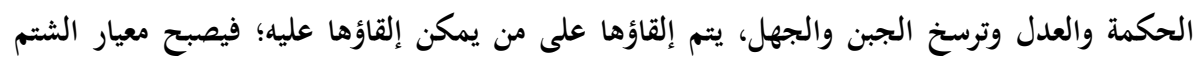

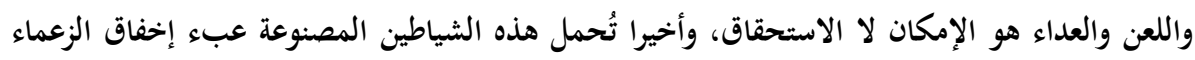
في تحقيق آمال وتخفيف آلام أتباعهم.

3. فكثيرا ما تمارس الفئات المتغلبة اقتصاديا - للحفاظ على مكاسبها- سياسات اقتصادية

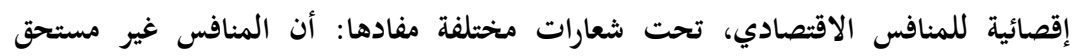

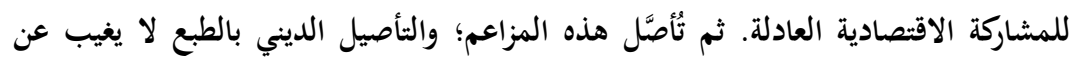

مشهل كهذا.

4. فكثير من مظاهر التعصب والعداء بين بني البشر مردها إلى أن كثيرين من أتباع الثقافات

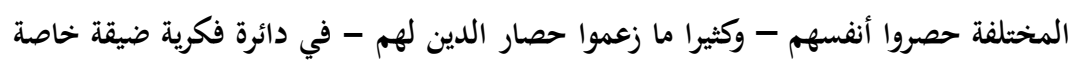

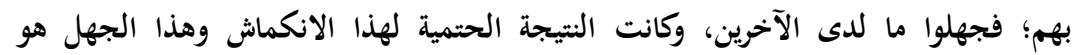

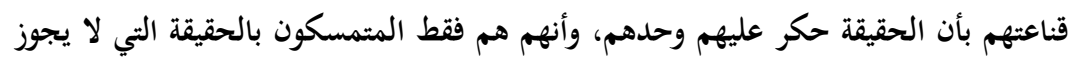

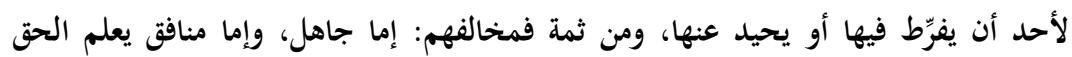

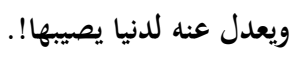

5. نتيجة: الخلط بين المعاني: اللغوية، أو الاصطلاحية، أو المجازية؛ أو الخلط بين معاني

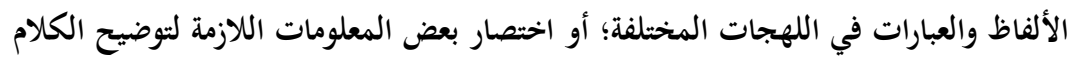

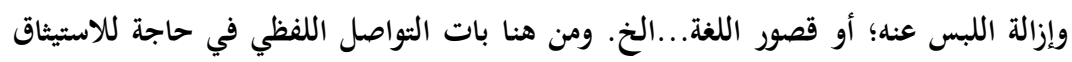

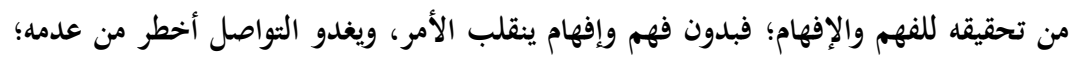
فكثير من الخلافات سواء الفكرية أو السياسية أو الاجتماعية تنشأ من إساءة التفاهم اللغوي.

6. إن قراءة الثاريخ تمدنا بأمثلة لا حصر لها - ليس هنا موضع بسطها- للعداوة ذات البواعث

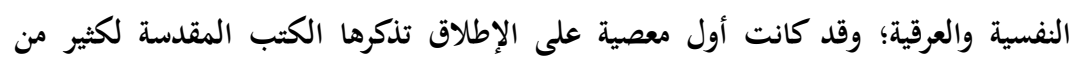


الأديان بدافع الغيرة وبدافع الاستعلاء العرقي وهي معصية إبليس في رفضه السجود لآدم.

وكانت المعصية الأولى على الأرض بدافع الغيرة وهي قتل قابيل لهابيل.

7.

8.

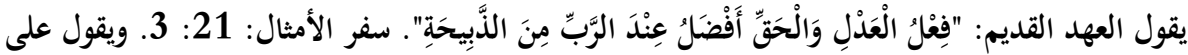

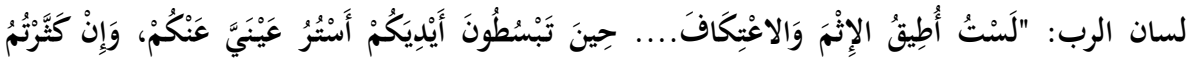

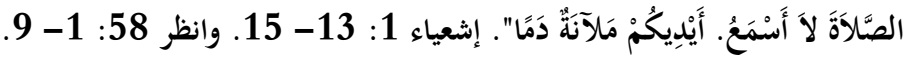

ويقول العهد الجديد على لسان المسيح -عليه السلام- : "إنِّي أُرِيدُ رَحْمَةً لاَ ذَبِحَةًّ". إنجيل متى: 9 13. بل وتجعل المسيحية من الالتزام الخلقي مع الناس الخطوة الأولى في الطريق نحو الله: فيقول العهد

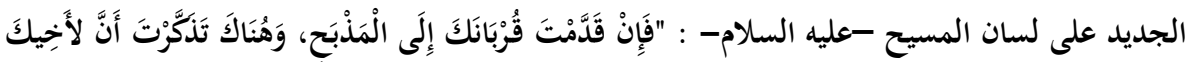

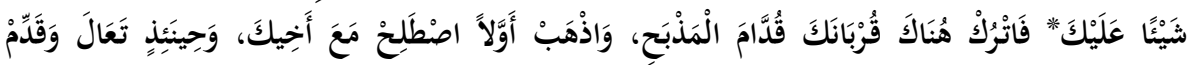

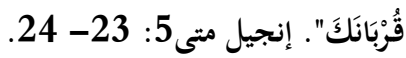

ويقول النبي علهولسلمّ : "إنما بعثت لأتمم مكارم الأخلاق". رواه: أحمد، ومالك، والبخاري في الأدب المفرد، والحاكم، والبيهقي في الشعب، وصححه الألباني في السلسلة الصحيحة. وعند بعضهم: "لأتمم صالح الأخلاق". وكذلك يجعل الإسلام من الالنزام الخلقي مع الناس الخطوة الأولى في الطريق نحو الله؛

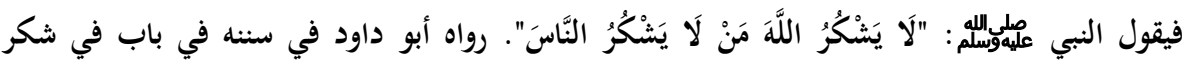

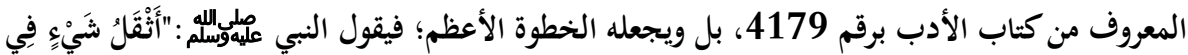

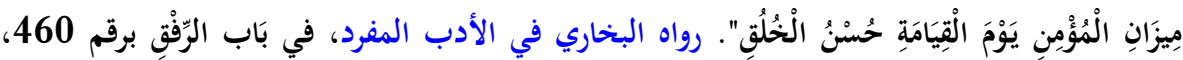

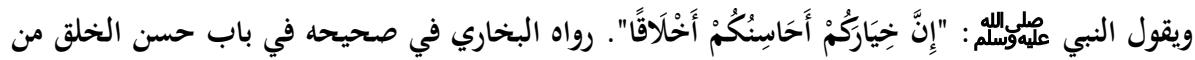

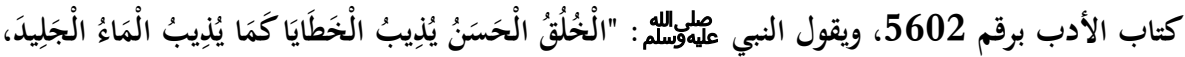

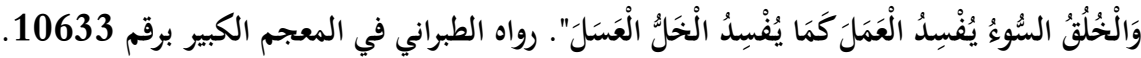
9 9. راجع لمزيد من التفصيلات حول ترتيب الأدلة كتابنا: الحوار مع الآخر، خطأ ترتيب الأدلة من الأقوى للأضعف، ص صـ 186: 188.

http://st-takla.org/Bibles/BibleSearch/search.php $\quad .10$ 
11. يقول الجويني في ذلك: "كل مجتهد في الفروع مصيب عندنا، ومن قال إن المصيب واحد

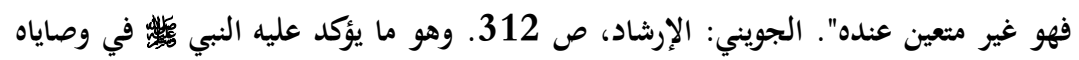

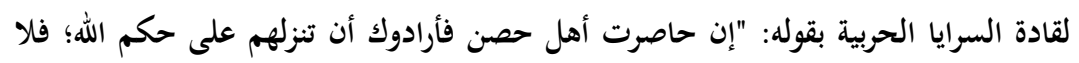

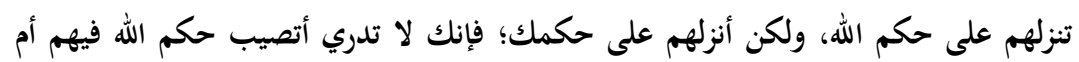

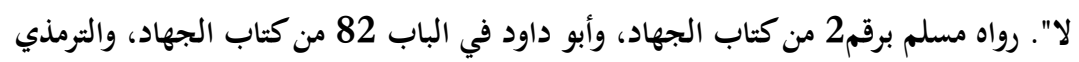

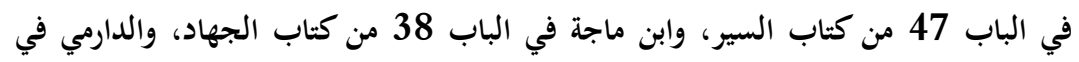

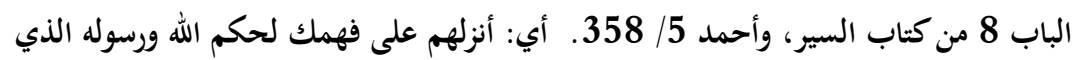

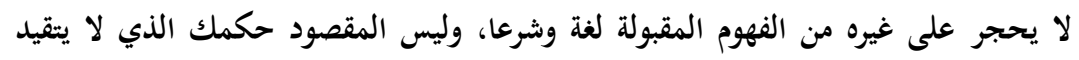

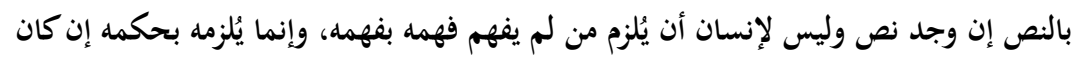
قاضيا أو حاكما، وفرق بين الإلزام بالحكم والإلزام بالفهم.

$$
\text { 12. انظر: قوجمان: قاموس عبري عربي، ص1014. }
$$

13. ويُعد يهودا هنَّاسي آخر التنائيم - رواة المشنا- وأول الأمورائيم -علماء الجمارا- انظر : متن

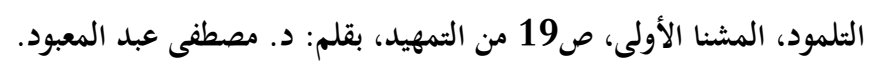

14. انظر: السابق، ص ص19: 23 من التمهيد. وانظر: التلمود البابلي، ص ص4: 14 من في

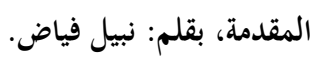

15. وتنقسم أسفار الأنبياء إلى ثلاث مجموعات: الأسفار التاريخية، وأسفار الأنبياء الكبار، وأسفار

$$
\text { الأنبياء الصغار. }
$$

16. بولس الرسول: ويعرف أيضًا ببولس الطرسوسي أو القديس بولس (أحيانًا يُكتب اسمه بالعربية

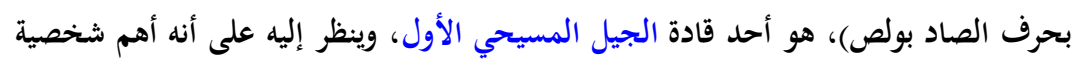

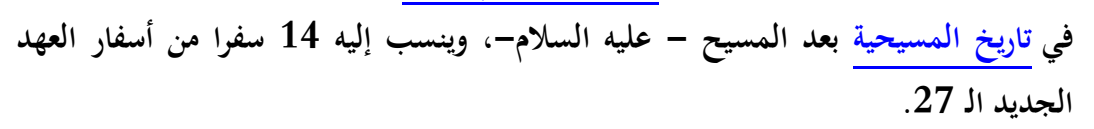

17. انظر : رسالة بولس الرسول الثانية إلى أهل كورنثوس 3: 14. 18. وذلك لأن المسيحية ديانة دعوية بعكس اليهودية. 19. انظر: الشوكاني: إرشاد الفحول، 11/ 119: 120. وانظر: حسب الله: أصول التشريع الإسلامي، ص17. - (19. 
20. واجع: ابن منظور: لسان العرب مادة (سنن).

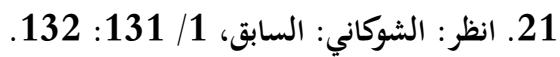

22. مجلة أديان، الإصدار الأول 2011م، ص9.

23. المشنا الرابعة، المبحث التاسع: آفوت أو الآباء، الفصل الأول، الفقرة (ل)، ص274.

24. والجويم كلمة عبرية مفردها جوي شوأه أو غوي، وتعني في اللغة العبرية: غير اليهودي. انظر: قوجمان: قاموس عبري عربي، ص 97. أو "الأغيار" كما يسميهم اليهود أحيانا.

25. انظر المشنا السادسة، المبحث الثامن: مكشرين أو إعداد الأطعمة لقبول النجاسة، الفصل

$$
\text { الثاني، الفقرة (ح)، ص349. }
$$

26. الثروة الدائمة: مصطلح يعبر عن اشتراط شريك في التجارة على شريكه المشاركة في الربح دون الخسارة. والعبارة بها غموض في تحديد الفاعل و المفعول.

27. المشنا الرابعة، المبحث الثاني: بابا مصيعا أو الباب الأوسط، الفصل الخامس، الفقرة (و)،

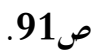

28. المشنا الرابعة، المبحث الأول: بابا قاما أو الباب الأول، الفصل الرابع، الفقرة (ج)، ص54.

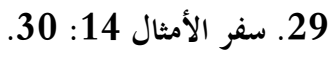

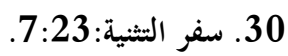

31. 3فر اللاويين 19: 33- 34.

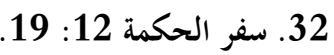

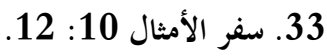

34. سفر الحكمة 7: 21-23 .

35. السابق 1: 6.

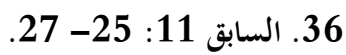




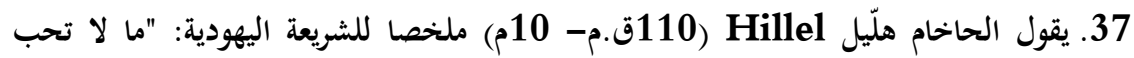

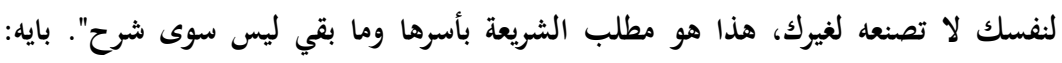

$$
\text { 38. سفر التثنية 10: 17- الخلاق الإنيل، ص161. } 19 .
$$

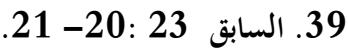

40. بالة يوحنا الرسول الأولى 3: 18.

$$
\text { 41. إنجيل يوحنا } 3 \text { : } 16 .
$$

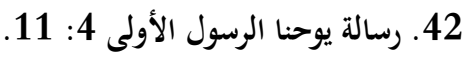

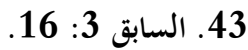

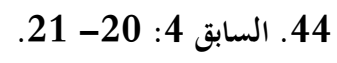

45. يقول التفسير التطبيقي للكتاب المقدس: "عندما يدخل إنسان إلى الإيمان المسيحي يصبح

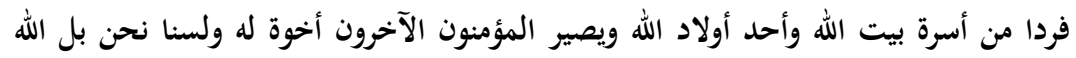

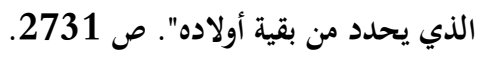

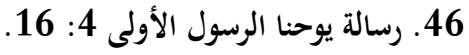

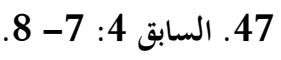
48. رسالة بولس الرسول إلى أهل رومية 5: 6- 8. 49. إنجيل متى 5: 44- 48. وانظر إنجيل لوقا 6: 27- 32. 50. رسالة بولس الرسول الأولى إلى تيموثاوس 1: 5. 51. إنجيل متى 22: 36-39. 52. انظر: الأب فاضل سيداروس اليسوعي وآخرون: معجم اللاهوت الكتابي، ص624. 53. إنجيل لوقا 10: 25- 5 - 5 - 5 
54. - 5 وسالة بولس الرسول إلى أهل رومية 13: 8.

55. رسالة بولس الرسول الأولى إلى أهل كورنثوس 13:13.

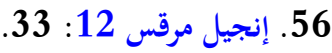

57. - 5 رسالة بولس الرسول إلى أهل كولوسي 3: 14.

58. رسالة بولس الرسول الأولى إلى أهل كورنثوس 13: 4- 8.

59. السابق 8: n

60

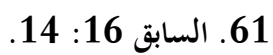

62. رسالة يوحنا الرسول الأولى 3: 15. وانظر متى 5: 21- 22.

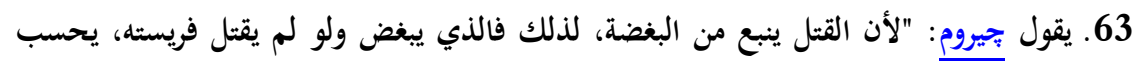

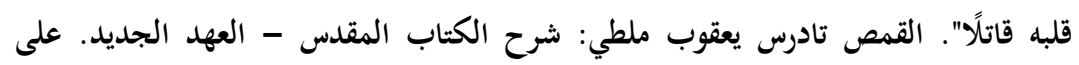

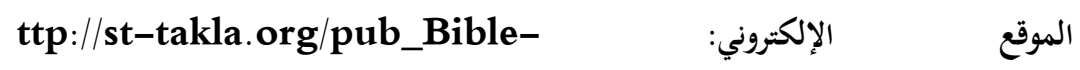
Interpretations/Holy-Bible-Tafsir-02-New-

Testament/Father-Tadros-Yacoub-Malaty/23-ResalatYouhanna-Al-Oula/Tafsir-Resalat-Youhana-I_01Chapter-03.html 64. انظر ابن منظور: لسان العرب، مادة حبب؛ والزبيدي: تاج العروس، مادة حبب. 65. وهو ما تشير إليه معاني (الصفاء والنقاء والهدوء والخضوع). 66. وهو ما تشير إليه معاني (الراحة والشفاء، والمساندة والاهتمام). 67. وهو ما تشير إليه معاني (التناسق والنماء والإثمار). 68. ابن قيم الجوزية، روضة المحبين ونزهة المشتاقين، ص33. وانظر ابن منظور: لسان العرب مادة ودد. 
69 أبو هلال العسكري: الفروق اللغوية، الباب السابع، الفرق بين الحب والود، ص122.

70. محمد راتب النابلسي، موسوعة النابلسي للعلوم الإسلامية، العقيدة الإسلامية، أسماء الله الحسنى، اسم الله الودود.

71. ابن حجر العسقلاني: فتح الباري شرح صحيح البخاري، كتاب الأدب، باب رحمة الناس والبهائم.

72. انظر على سبيل المثال: ابن منظور: لسان العرب حرف الحاء (حبب)، وحرف الدال (ودد). 73. صدر منها بحثان: الأول: (الإحسان إلى مخالف الإيمان: العطاء والدعاء نموذجا). والثاني: (التحية والابتسام لمخالف الإيمان).

74. - 76 القصص 56

75. القرطبي: الجامع لأحكام القرآن تفسير الآية 56 من سورة القصص. 76. البغوي: معالم التنزيل، تفسير الآية 56 من سورة القصص. 77. الطبري: جامع البيان عن تأويل القرآن، تفسير الآية 56 من سورة القصص. 78. محمد بن صالح العثيمين [المفتي الأسبق للمملكة العربية السعودية]: القول المفيد على كتاب التوحيد، الجزء الأول، باب قول الله تعالى: "إنك لا تهدي من أحببت".

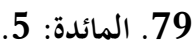

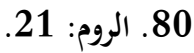

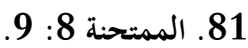

82 82 رواه مسلم في صحيحه، كتاب الإيمان، باب بيان كون الإيمان بالله تعالى أفضل الأعمال. 83. 84. محمد رشيد رضا: تفسير المنار، تفسير الآية 24 من سورة التوبة. 85. كما سيأتي بيانه في حديثنا عن تفسير الآية 22 من سورة المجادلة. 


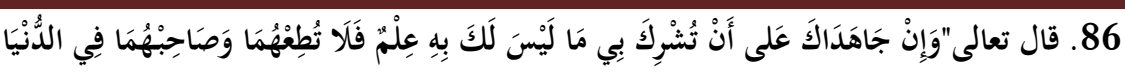

$$
\text { مَعْرُوفًا". لقمان: } 15 .
$$

87. يخالفنا الرأي هنا كثير من العلماء قديما وحديثا؛ فيقول ابن تيمية: "المؤمن تجب موالاته وإن

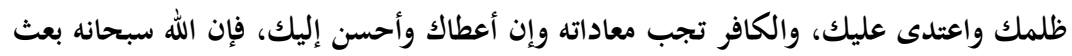

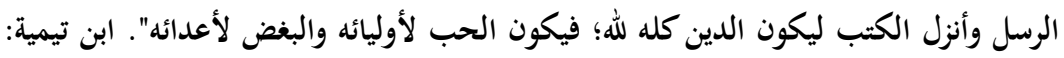

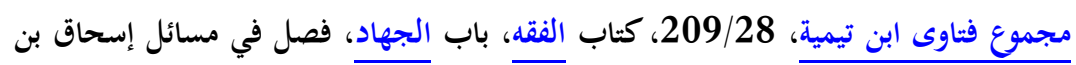
منصور. ط مجمع الملك فهد.

ويقول السعدي: "فلا يكون العبد مؤمنا بالله واليوم الآخر حقيقة، إلا كان عاملا على مقتضى إيمانه ولوازمه، من محبة من قام بالإيمان وموالاته، وبغض من لم يقم به ومعاداته، ولو كان أقرب النان الناس إليه.

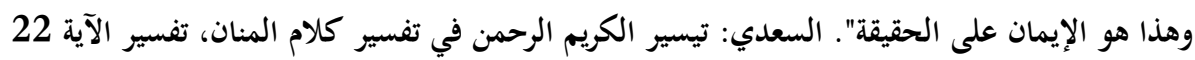

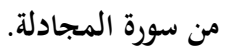

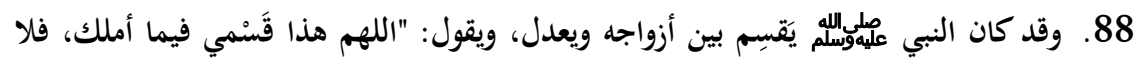

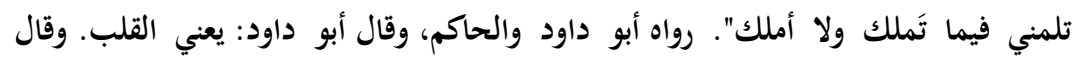
الحاكم: الحديث على شرط مسلم، ووافقه الذهبي.

89. المجادلة: 22. "من حادّ الله ورسوله: أي من عادى اللّهَ ورسولَه". الطبري: جامع البيان عن تأويل القرآن، تفسير الآية 22 من سورة المجادلة. 90. وهذا أمر مشهود، نراه ورآه القائل:

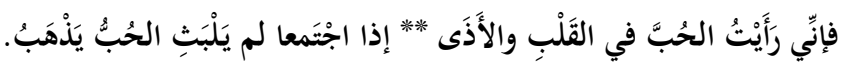
صدر الدين علي بن أبي الفرج بن الحسن البصري: الحماسة البصرية، تتمة باب الأدب، باب النسيب

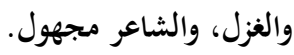

$$
91
$$

92. يقول ابن تيمية: "فالمحب ... [لله] لو كان موادا لمحاده، لكان محبا لاجتماع مراد

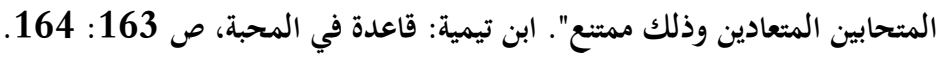


93. رواه مسلم في صحيحه، كناب البر والصلة والآداب، باب تراحم المؤمنين وتعاطفهم

وتعاضدهم.

94. ابن كثير، تفسير القرآن العظيم، تفسير الآية 22 من سورة المجادلة.

عن ابن عمر رضي الله عنهما "قال لما توفي عبد الله بن أبي ابن سلول جاء ابنه عبد الله بن

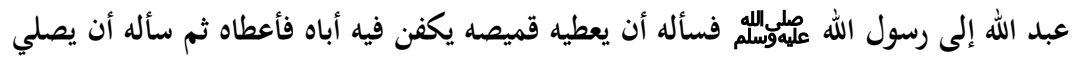

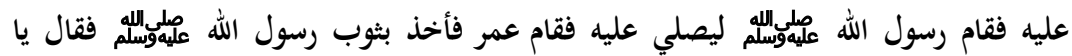

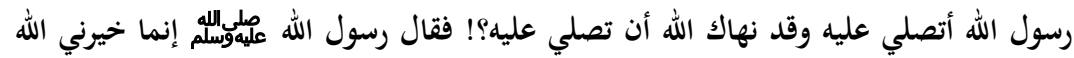
فقال: (استغفر لهم أو لا تستغفر لهم إن تستغفر لهم سبعين مرة) وسأزيده على سبعين. قال:

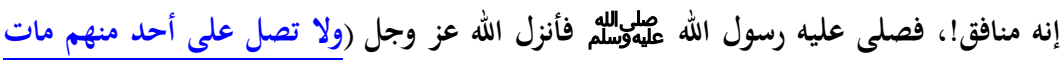

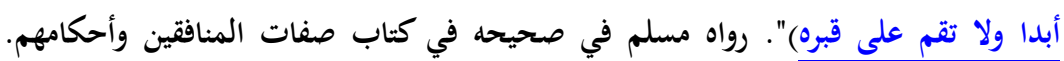

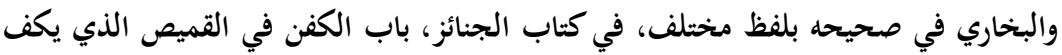
أو لا يكف ومن كفن بغير قميص.

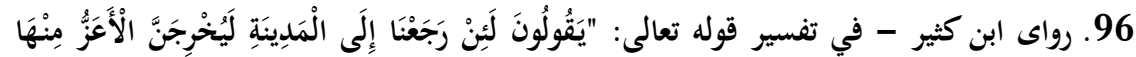

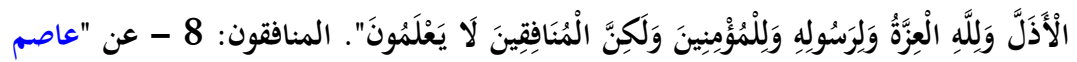

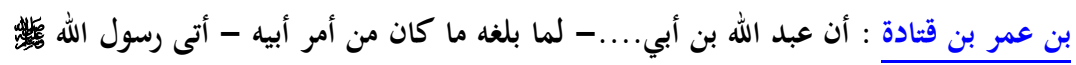

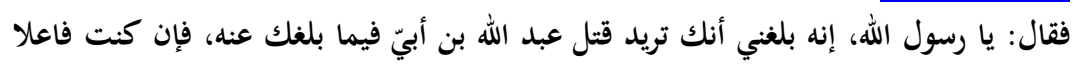

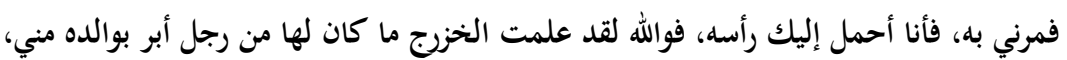

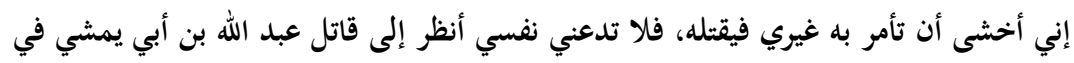

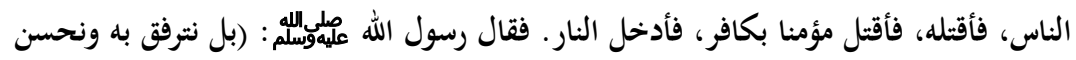

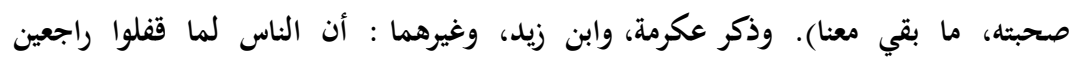

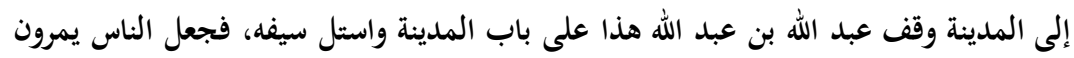

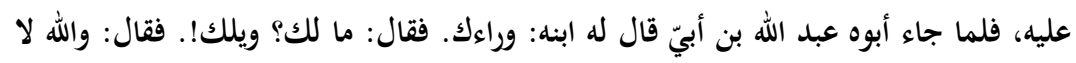

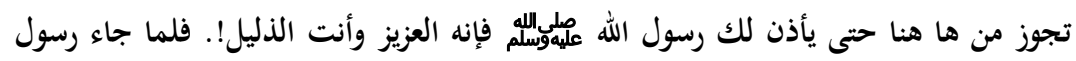

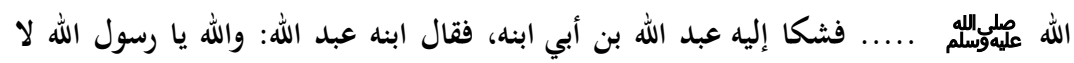

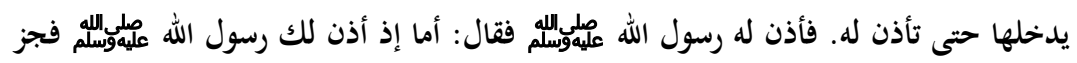

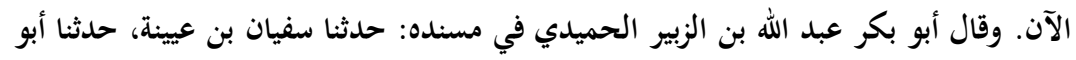

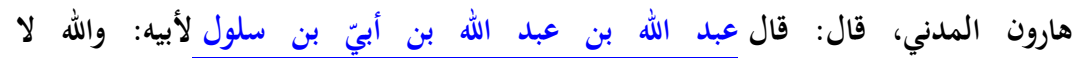

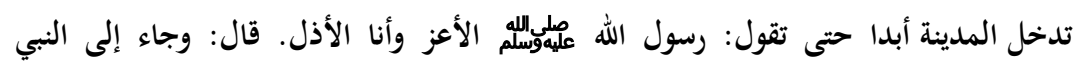


علهلوسلاله فقال: يا رسول الله، إنه بلغني أنك تريد أن تقتل أبي، فوالذي بعثك بالحق ما تأملت

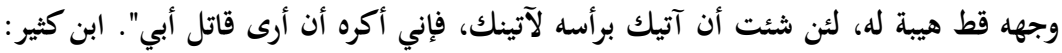
تفسير القرآن العظيم، تقسير الآية 8 من سورة المنافقون.

97. ويخالفنا العثيمين الرأي حيث يجيز محبة من حاد الله ورسوله فيقول: "إن المودة للقرابة لا تُعد

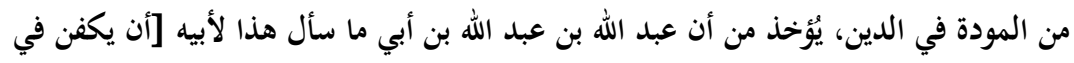

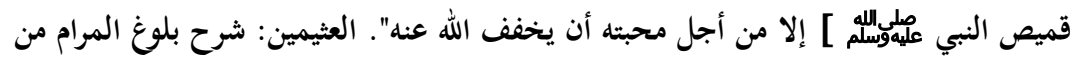

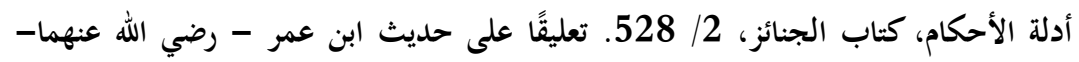

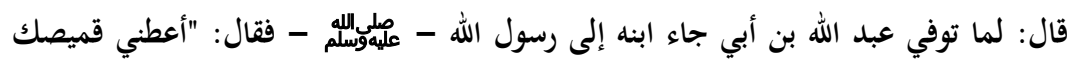

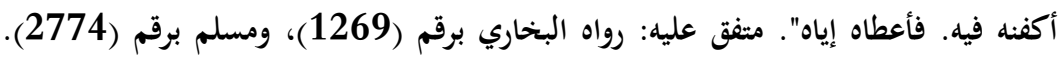

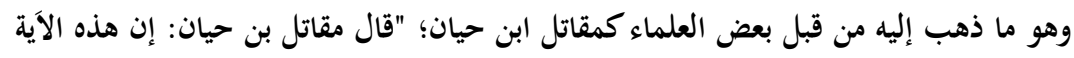

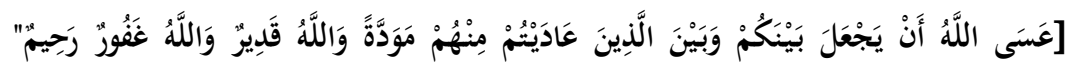

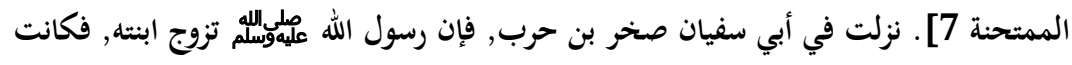

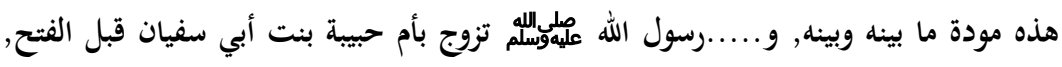

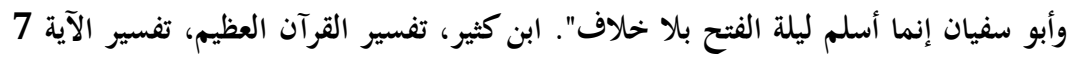

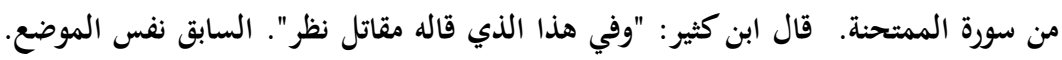

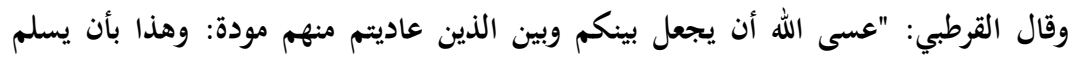
الكافر". القرطبي: الجامع لأحكام القرآن، تفسير الآية 7 من سورة الممتحنة.

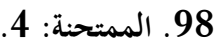

99. وهنا يخالفنا الرأي كثير من العلماء كالدكتور.عبد الرحمن بن ناصر البراك [عالم دين سعودي

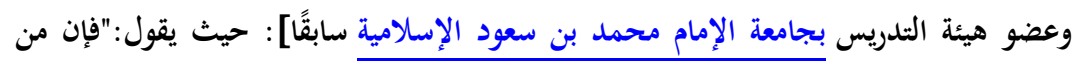

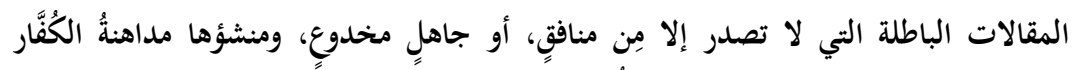

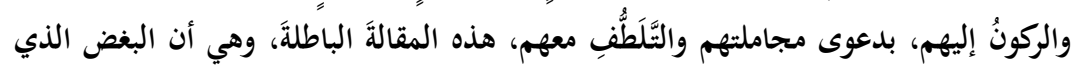

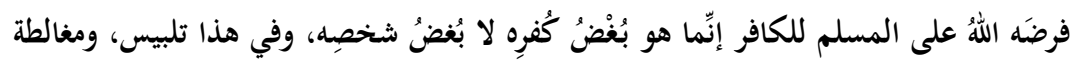

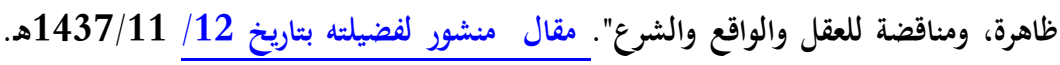

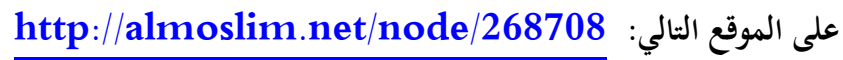

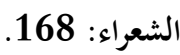




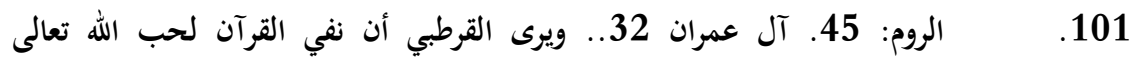
للكافرين لا يعني سوى أنه "لا يغفر لهم". القرطبي: الجامع لأحكام القرآن، تفسير الآية 32

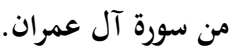

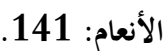

ابن كثير: تفسير القرآن العظيم، تقسير الآية 141 من سورة الأنعام.

رواه أحمد في المسند برقم (18524) وحسنه الألباني في "صحيح الترغيب" برقم

رواه عبد الرزاق والحميدي والطيالسي وأحمد، وصححه الترمذي في سننه في باب فضل التوبة من كتاب الدعوات، وابن حبان في صحيحه.

رواه الحاكم في المستدرك على الصحيحين، كتاب الأطعمة، باب المرء على دين

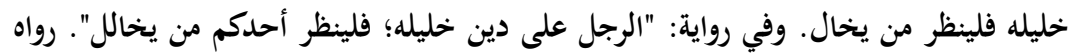
الترمذي في سننه في كتاب الزهد، باب ما جاء في أخذ المال بحقه، وغيرهما.

قال ابن منظور: "الخلة: الصداقة المختصة التي ليس فيها خلل،.... والمحبة التي

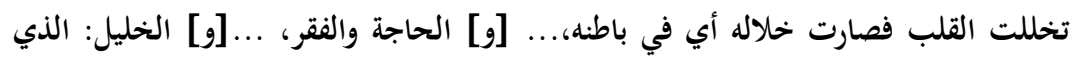

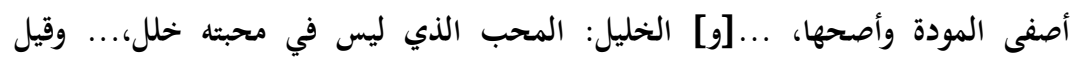

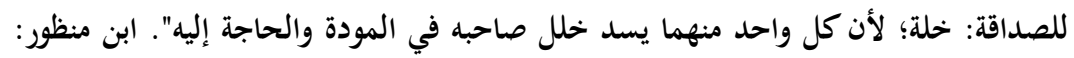
لسان العرب، حرف الخاء، خلل.

فالدين في اللغة والاصطلاح لا يعني العقيدة والشريعة فحسب، فالدين يعني:

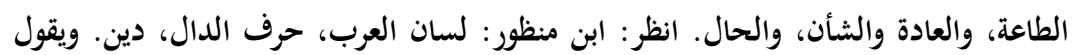

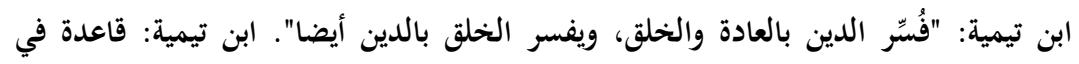
المحبة، ص 94. وقال المباركفوري: "على دين خليله: أي على عادة صاحبه وطريقته وسيرته".

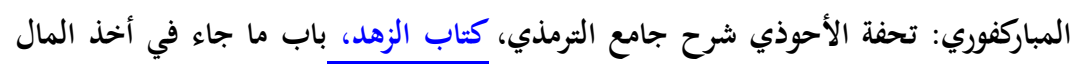
بحقه.

رواه البخاري في صحيحه في كتاب الأدب، باب المقة من الله تعالى. ومسلم بلفظ .109 مختلف في كتاب البر والآداب، باب إذا أحب الله عبدا حببه إلى عباده. 


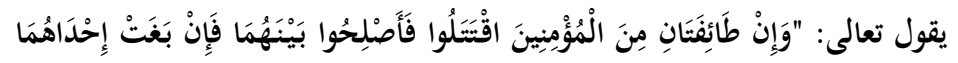

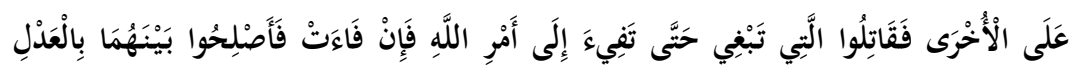

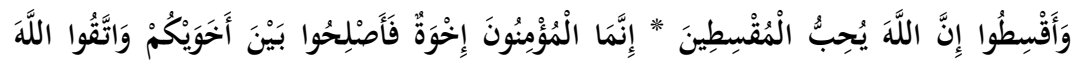

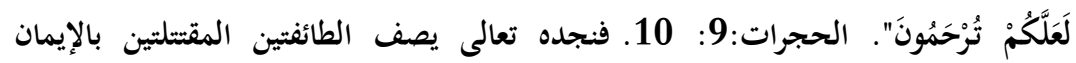
وبالأخوة.

وهما: ألا تكون محبتهم أكبر من محبة المؤمن لله ورسوله وجهاد في سبيله، وألا يكون الكافر محادا لله ولرسوله.

يقول عبد الرزاق عفيفي (عضو هيئة كبار العلماء بالمملكة العربية السعودية): "من

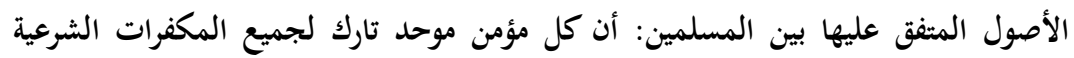

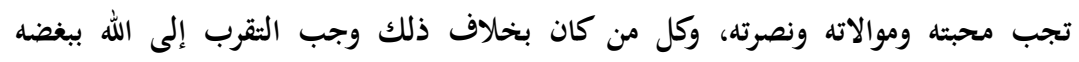

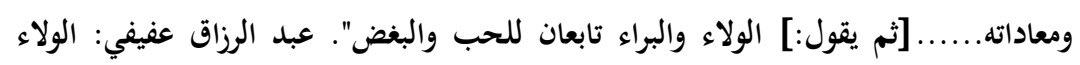

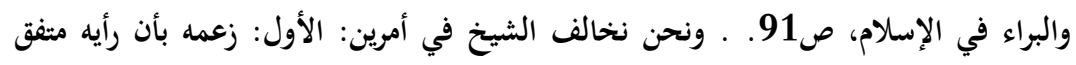

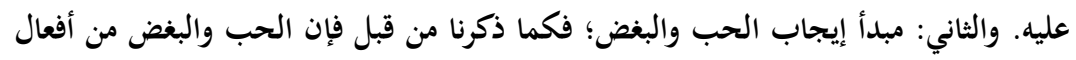

$$
\text { القلوب وأفعال القلوب لا يدخلها أمر ولا نهي. }
$$

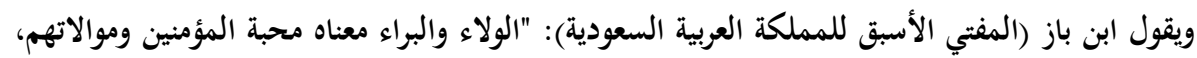

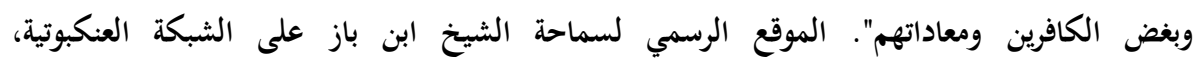
https://binbaz.org.sa/old/37631.

من الجدير بالملاحظة أن موضوع الولاء والبراء لا نجد عنه في كلام السلف من

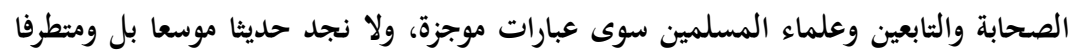

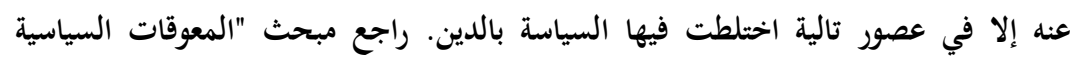
للتعايش مع الآخر" من كتابنا (التعايش مع الآخر).

$$
\text { الأعراف:27. }
$$




$$
\begin{aligned}
& \text { انظر: القرطبي: الجامع لأحكام القرآن، تفسير الآية } 257 \text { من سورة البقرة. } \\
& \text { انظر : القرطبي: السابق، تفسير الآية } 11 \text { من سورة محمد. }
\end{aligned}
$$$$
\text { المائدة: } 51 .
$$

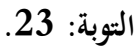

يقول محمد رشيد رضا :"فإنما النهي عن ولاية الحرب والنصرة للكافرين المحاربين

لنا لأجل ديننا". محمد رشيد رضا: تفسير المنار، تفسير الآية 23 من سورة التوبة. ويقول الطبري في تفسيره لهذه الآية: "يقول تعالى ذكره للمؤمنين به وبرسوله: لا تتخذوا آباءكم وإخوانكم بطانة وأصدقاء تفشون إليهم أسراركم وتطلعونهم على عورة الإسلام وأهله, وتؤثرون

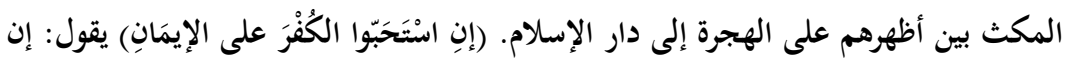

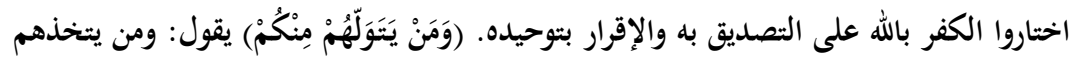
منكم بطانة من دون المؤمنين, ويؤثر المقام معهم على الهجرة إلى رسول الله ودار الإسلام

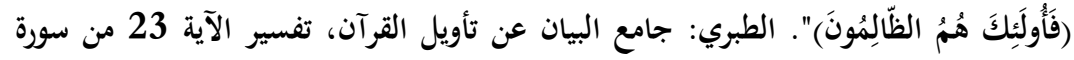

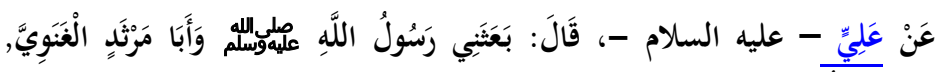

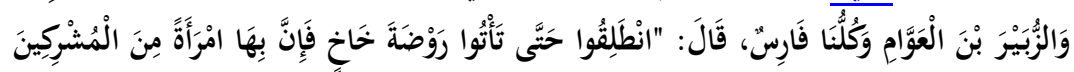

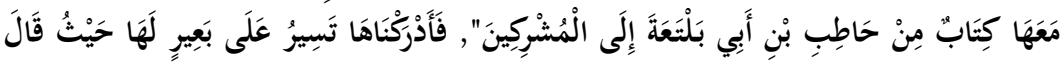

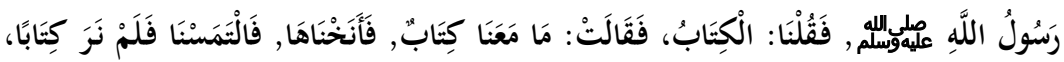

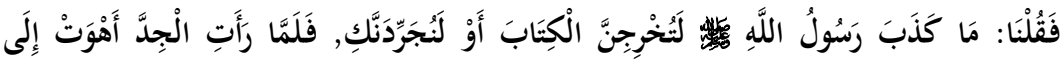

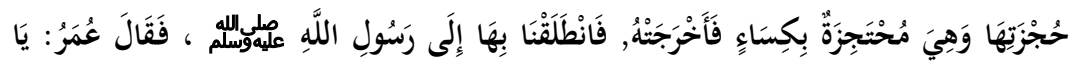

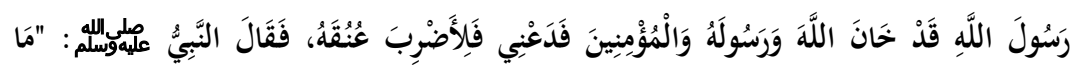

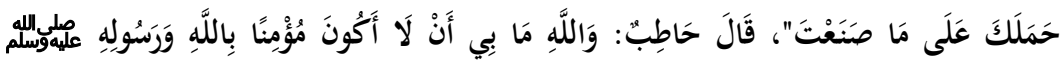

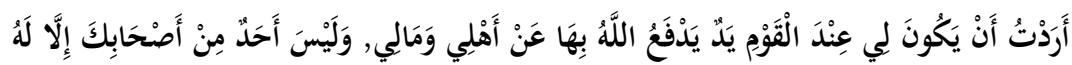

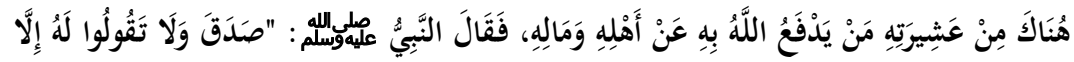

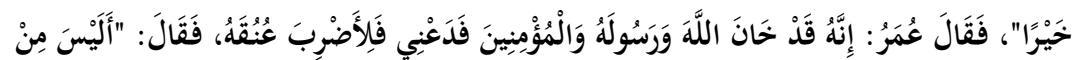

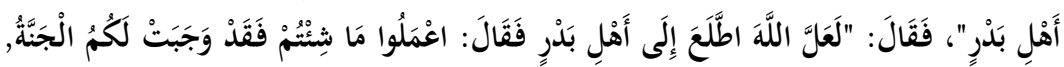

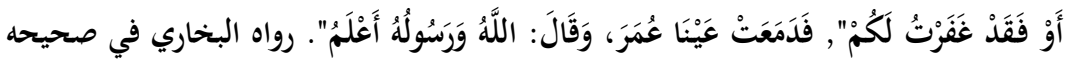


في بَاب فَضْلُ مَنْ شَهِهَ بَدْرًا، من كِتَاب الَْفََازِي، وفي مواضع أخرى، وأحمد في المسند، والنسائي في سننه، والحاكم في المستدرك، وابن حبان في صحيحه.

يقول دستور المدينة: "وأن على اليهود نفقتهم، وعلى المسلمين نفقتهم، وأن بينهم

النصر على من حارب أهل هذه الصحيفة، وأن بينهم النصح والنصيحة والبر دون الإثم".

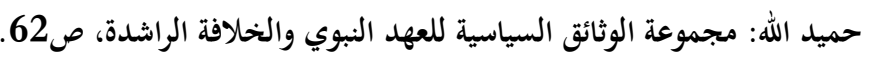

رواه البخاري في صحيحه في باب "أعن أخاك ظالما أو مظلوما" من كتاب

"المظالم".

وليس هناك ما يمنع من وصف الكافر بالأخوة من وجهة النظر الإسلامية فكثيرا ما

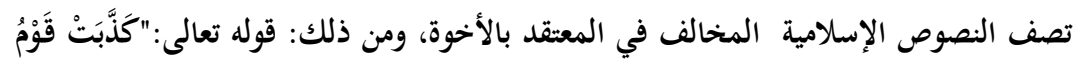

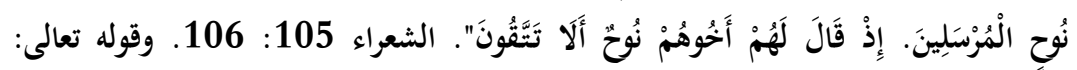

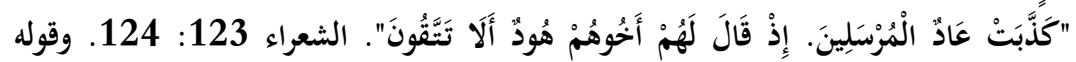

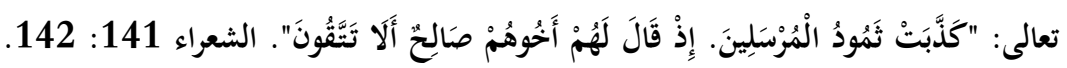

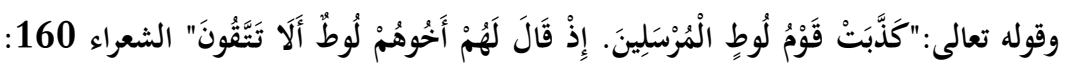

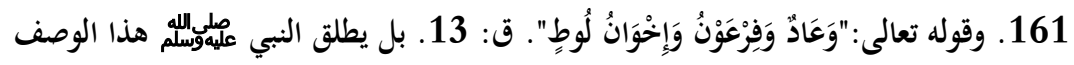

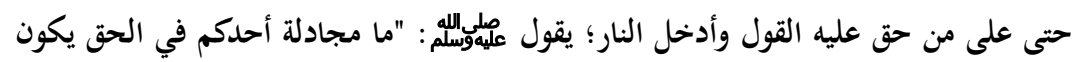

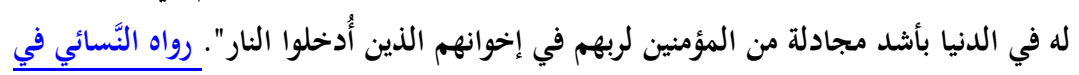

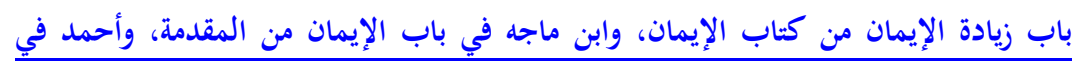

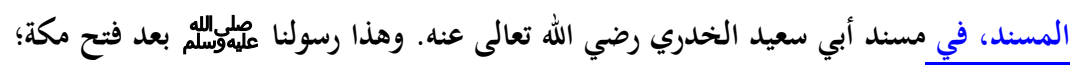

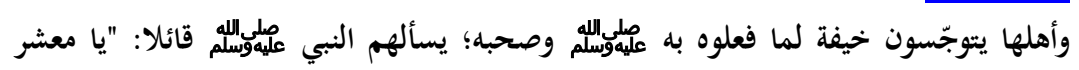

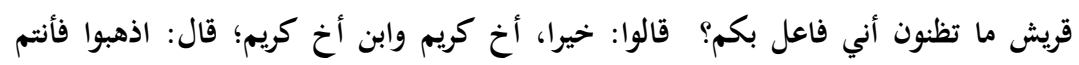

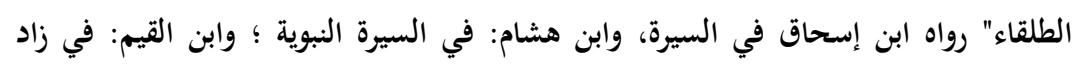

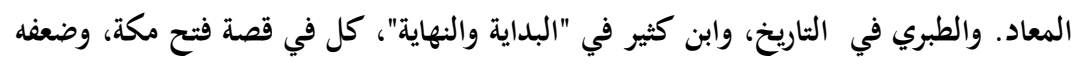

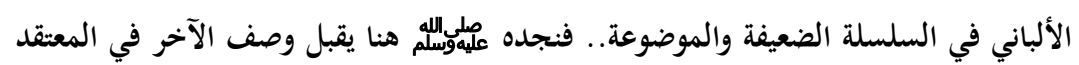
بالأخوة ، بل ويقيم ما يترتب على ذلك من حقوق الأخوة: من عفو ومسامحة.

$$
\text { قبل مبعثي. }
$$

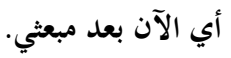


130.

رواه المعافى بن زكريا في كتابه الجليس الصالح الكافي والأنيس الناصح الشافي،

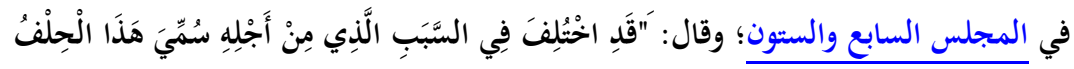

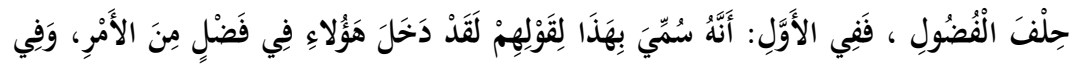

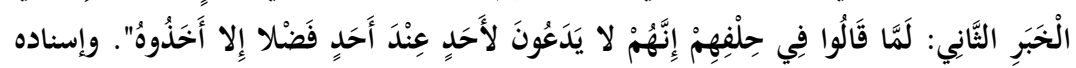

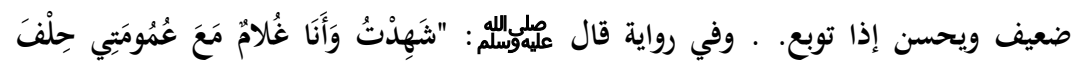

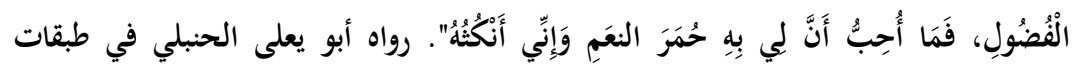

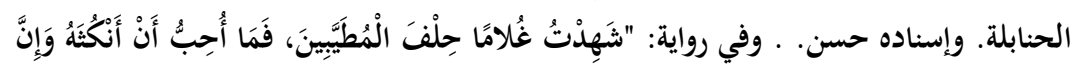

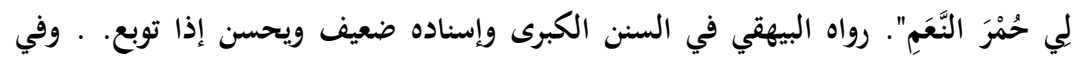

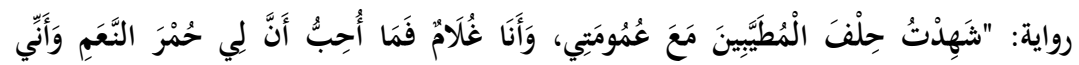
أَنْكُُُهُ". رواه أحمد في المسند برقم 1589.

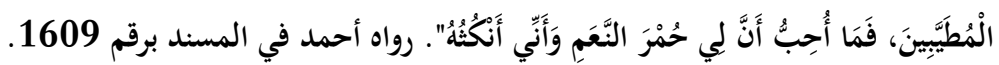

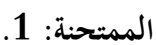

وهو ما يؤكد عليه الغزالي في كتابه: التعصب والتسامح بين المسيحية والإسلام، ص

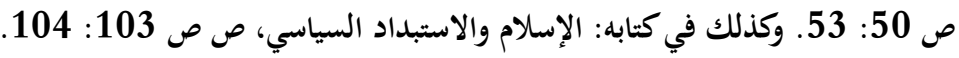

\begin{tabular}{|c|}
\hline النساء: 101: 102. \\
\hline التوبة: 8. \\
\hline التوبة: 10. \\
\hline التوبة: 13. \\
\hline
\end{tabular}

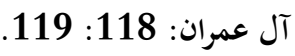
136

القرطب: الجامع لأحكام القرآن، تفسير سورة البقرة، تفسير الآية 105. 

142. الطبري: جامع البيان عن تأويل آي القرآن، تفسير سورة البقرة، تفسير الآية 105.
انظر: الجلالين: تفسير الجلالين، تفسير سورة البقرة، تفسير الآية 105.
علي بن أبي طالب: نهج البلاغة، تحقيق عبد العزيز سيد الأهل، شرح محمد عبده،

$$
\text { ج4 ص } 518 .
$$

انظر: المزمور 56: 4- 5. سفر إرمياء 23: 36. رسالة بولس الرسول الأولى إلى

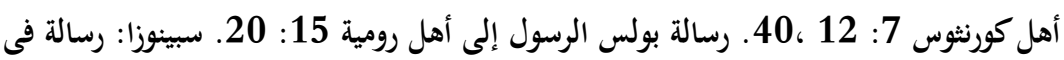

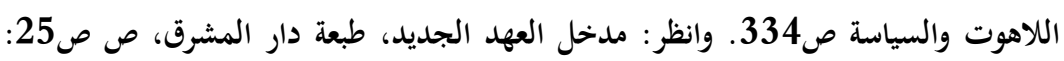
26 26 وانظر: الفاتيكان: البند 12من الفصل الثالث من دستور المجمع المسكونى للفاتيكان الثانى: "الوحى الإلهى"، ص130. وانظر : بايه: أخلاق الإنجيل، ص 189.

$$
\begin{aligned}
& \text { انظر: متى 5: } 17 . \\
& \text { الأنعام: } 90 .
\end{aligned}
$$

وأمام هذه الحقيقة: حصر بعض العلماء حجية قول الصحابي فيما اشتهر ولم يُعلم .148 له مخالف (وهو ما اصطلحوا على تسميته بالإجماع السكوتي)، وهذا غير مُسلَّم به أيضا فعدم المهاء العلم بوجود المخالف ليس علما بعدم وجوده.

وأمام هذه الحقيقة حصر بعض آخر من العلماء حجية قول الصحابي فيما لا يدرك بالرأي - كالغيبيات-

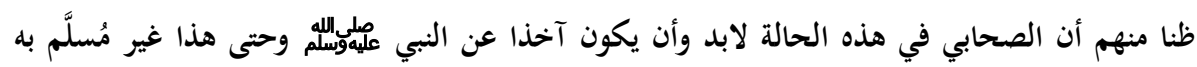

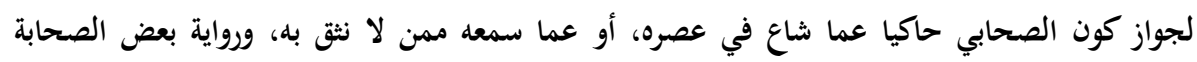
للإسرائيليات خير دليل على ذلك.

ونتفق مع من ذهب إلى حجية قول الصحابة إذا اشتهر الرأي ولم نعلم له مخالفا إذا كانت المسألة مما لا الا

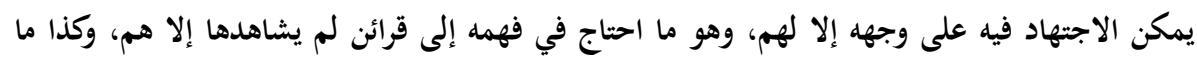
احتاج إلى قوة في معرفة لغة العرب. انظر في حجية قول الصحابي: الشاطبي: الموافقات 302/3، حسب الله: أصول التشريع الإسلامي، ص

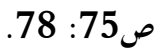


وعلى كل حال، لم يحدث إجماع سكوتي على رفض محبة مخالف الملة المسالم عند السلف، ولا علاقة لدراستنا بالغيبيات فموضوعنا في المعاملات.

أي: أنزلهم على فهمك لحكم الله ورسوله الذي لا يحجر على غيره من الفهوم

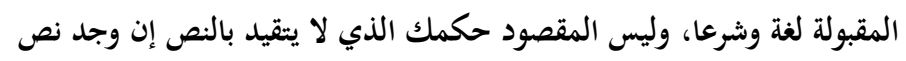

رواه مسلم برقم 2 من كتاب الجهاد، وأبو داود في الباب 82 من كتاب الجهاد،

وغيرهما. وجدير بالتنويه هنا أن المسلم لا يطبق النصوص القرآنية والنبوية وإنما يطبق فهمها لهن غير المعصوم الذي فهمه العلماء الثقات.

$$
\text { انظر: السخاوي: المقاصد الحسنة،1 /310. }
$$

القرطبي: الجامع لأحكام القرآن، تفسير الآية 42 من سورة البقرة.

$$
\text { ونحو هذا يروى من قول علي. انظر: السخاوي: المقاصد الحسنة، } 1 \text { /311. }
$$

فالنص اليهودي والمسيحي المقدس المعاصر هو في حقيقته تفسير لنص مقدس مفقود،

ومن ثمة لا تضيف تفسيرات هذه التفسيرات (شروح هذه النصوص المقدسة) في الغالب جديدا ذا ها

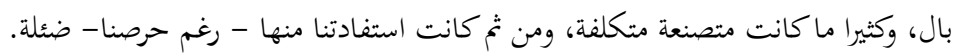

وما يتعلق بالعدد والتعداد فمعرفته يسيرة ولو اقتصر الأمر عليه لكان ترتيب الأديان في

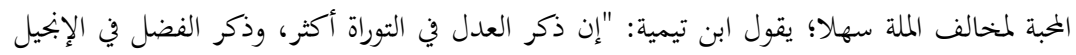
أكثر، والقرآن جمع بينهما على غاية الكمال". ابن تيمية: الجواب الصحيح لمن بدل دين المسيح،

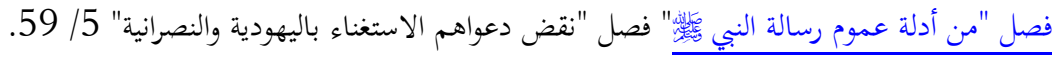


- معالم التنزيل، تحقيق: محمد عبد الله النمر -

عثمان جمعة ضميرية - سليمان مسلم الحرش،

د.ط، الرياض: دار طيبة، 1409هـ -

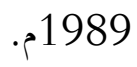

ه الجلالين (جلال الدين المحلي، وجلال الدين السيوطي): - تفسير الجلالين، ط1، القاهرة: دار الحديث، د.ت.

$$
\text { • رشيد رضا (محمد رشيد بن علي رضا): }
$$

- - تفسير القرآن الحكيم (تفسير المنار)، د.ط،

القاهرة: الهيئة المصرية العامة للكتاب، 1990

• السعدي (عبد الرحمن بن ناصر بن عبد الله):

- تيسير الكريم الرحمن في تفسير كلام المنان،

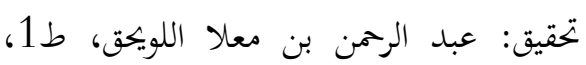

دمشق: مؤسسة الرسالة، 1420هـ - 2000م.

ه الطبري (أبو جعفر محمد بن جرير): 
- - - -

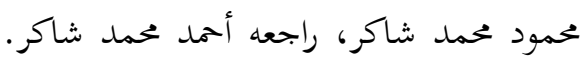

القاهرة: د.ط، دار المعارف، 1957م. راحكه احدد

• القرطبي (أبو عبد الله محمد بن أحمد الأنصاري):

- - الجامع لأحكام القرآن، د.ط، القاهرة: دار

الشعب، د.ت.

$$
\text { • ابن كثير ( أبو الفداء إسماعيل بن كثير القرشي الدمشقي): }
$$

-

الكتب العربية عيسى البابي الحلبي، د.ت.

> كتب السنة النبوية وشروحها:

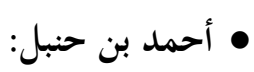

- مسند أحمد بن حنبل، د.ط، بيروت: دار

صادر، د.ت.

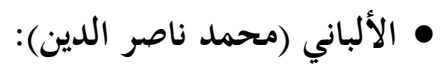

- - سلسلة الأحاديث الصحيحة، د.ط، د.م:

بيروت: المكتب الإسلامى، د.ت.

- - السلسلة الضعيفة والموضوعة، على الموقع

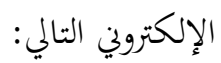

http://www.waqfeya.com/book.php?bid=505 


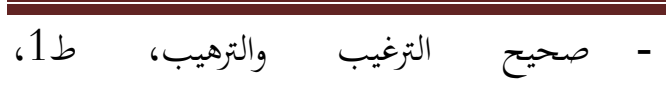

الرياض: مكتبة المعارف لنشر و والتوزيع،

$$
1421
$$

• البخاري (أبو عبد الله محمد بن إسماعيل بن إبراهيم بن المغيرة بن بزدزبة):

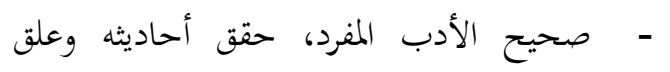

عليه : محمد ناصر الدين الألباني، ط4، الهادئ، وعلق

القاهرة: دار الصديق، 1418هـ - 1997م.

- صحيح البخاري، د.ط، القاهرة: مطابع

الشعب، د.ت.

• البيهقي (أبو بكر أحمد بن الحسين):

-

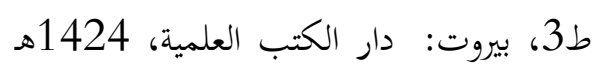

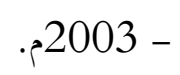

- شعب الإيمان، تحقيق: محمد السعيد بسيوني

زغلول، ط1، بيروت: دار الكتب العلمية،

$$
\text { • الترمذي (أبو عيسى محمد بن عيسى بن سورة): } 1410 \text { هـ. }
$$

- منن الترمذي، تحقيق وشرح: أحمد محمد

شاكر، ط2، القاهرة: مصطفى البابي الحلبي،

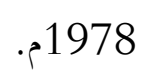

• الحاكم النيسابوري (أبو عبد الله محمد بن عبد الله): 
- المستدرك على الصحيحين، د.ط، بيروت: دار

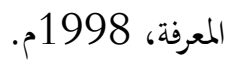

$$
\text { ابن حبان (محمد بن حبان بن أحمد بن حبان) }
$$

- صحيح ابن حبان، ترتيب: الأمير علاء الدين

علي بن بلبان الفارسي، حققه وخرج أحاديثه

وعلق عليه: شعيب الأرنؤوط، ط1، بين بيروت:

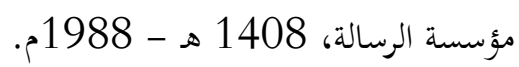

ابن حجر (شهاب الدين أبو الفضل العسقلاني).

- فتح الباري بشرح البخاري، د.ط، القاهرة: مصطفى البابي الحببي، 1959م.

• أبو داود (سليمان بن الأشعث بن إسحاق الأزدي السجستاني):

- - منن أبي داود، تعليق أحمد سعد علي، ط1،

القاهرة: ط مصطفى البابي الحلبي، 1952م. دأمديف

\section{• الطبراني (أبو القاسم سليمان بن أحمد بن أيوب اللخمي):}

- - المعجم الكبير، تحقيق: حمد عبد البجيد السلفي،

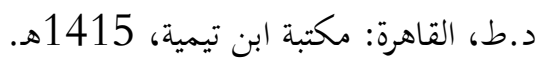

• ابن ماجه (أبو عبد الله بن يزيد القزويني):

- - منن ابن ماجه، تحقيق وتعليق: محمد فؤاد عبد

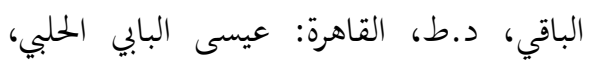

د.ت.

• مالك بن أنس: 
- - الموطأ، تحقيق: محمد علوي المالكي، ط1،

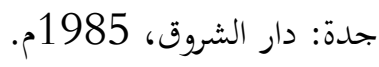

$$
\text { • المباركفورى (أبو العلا محمد عبد الرحمن بن عبد الرحيم): }
$$

- متفة الأحوذي بشرح جامع الترمذي، د.ط،

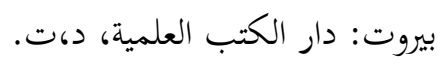

$$
\text { • مسلم (أبو الحسين مسلم بن الحجاج بن مسلم القشيري): }
$$

- صحيح مسلم بشرح النووي، د.ط، القاهرة: ط

مصطفى البابي الحلبي، د.ت.

• النسائي (أبو عبد الرحمن بن شعيب بن علي):

- - سنن النسائي، تحقيق: عبد الفتاح أبو غده،

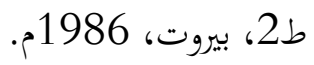

الكتابات المقدسة في اليهودية والمسيحية:

\section{• التلمود:}

التلمود البابلي، رسالة عبدة الأوثان، من سلسلة رسائل تلمودية (أ) ترجمة

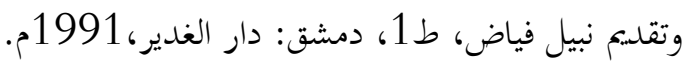

متن التلمود، المشنا، ترجمة د. مصطفى عبد المعبود سيد منصور، ط1،

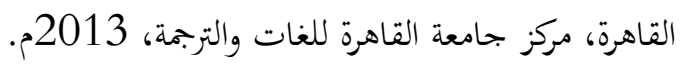

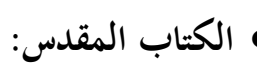

الكتاب المقدس، ط3، بيروت: دار المشرق، 1994 (طبعة معتمدة من بولس باسيم، النائب الرسولي للاتين). 
الكتاب المقدس على الموقع اللإلكتروني التالي: - الم

http://st-takla.org/Bibles/BibleSearch/search.php

>

$$
\text { • بارتون (الدكتور بروس) وآخرون: }
$$

-

القاهرة: شركة ماستر ميديا، 1997.

$$
\text { • ملطي (القمص تادرس يعقوب ملطي): }
$$

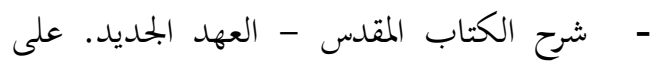

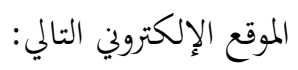

http://st-takla.org/pub_Bible-Interpretations/Holy-BibleTafsir-02-New-Testament/Father-Tadros-Yacoub-Malaty

\section{مجلات علمية:}

-

عن (المودة والرممة والمحبة في الأديان) لقاء مع الإن، عددان

الحاخام ستينساليتز، مركز الدوحة الدولي لحوار

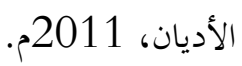

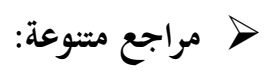

• - (ابن إسحاق (محمد بن إسحاق بن يسار المطلب):

- - السيرة النبوية، تحقيق: أحمد فريد المزيدي، ط1،

دار الكتب العلمية، 1424هـ 
- أخلاق الإنجيل، دراسة سوسيولوجية، ترجمة: د.

عادل العوا، ط1، دمشق: دار الحصاد، دراده سوسيوله ترجهه: دار

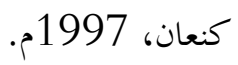

• ابن تيمية (أبو العباس تقي الدين أحمد بن عبد الحليم):

-

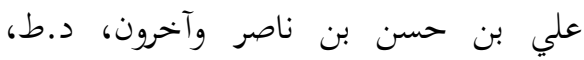

القاهرة، الرياض: دار العاصمة، 1419هـ / لن اصرون

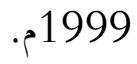

-

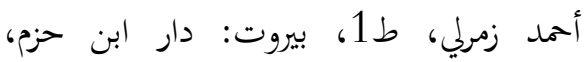

المكتب الإسلامي، 1999ه، 1420هـ

- - مجموع فتاوى ابن تيمية، د.ط، المدينة المنورة:

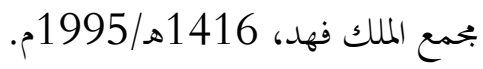

• الجويني (إمام الحرمين: أبو المعالي عبد الملك).

- - الإرشاد إلى قواطع الأدلة في أصول الاعتقاد،

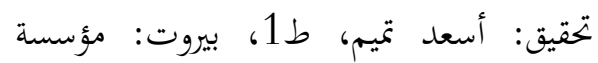

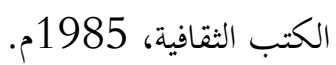

• حسب الله (على):

- أصول التشريع الإسلامي، د.ط، دار المعارف،

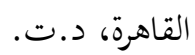




\section{• حميد الله (محمد):}

- بحموعة الوثائق السياسية للعهد النبوي والخلافة

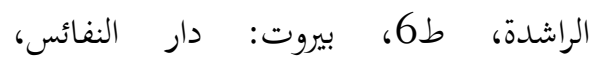

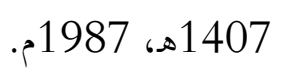

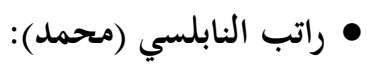

- موسوعة النابلسي للعلوم الإسلامية، العقيدة

الإسلامية، أسماء الله الحسنى، اسم الله الودود.

http://www.nabulsi.com/blue/ar/te.php?art=3576

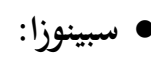

- رسالة في اللاهوت والسياسة، ترجمة وتقديم د.

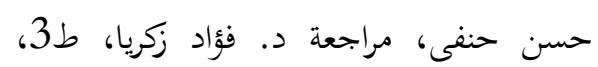

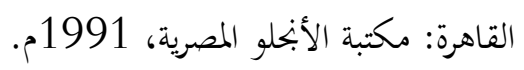

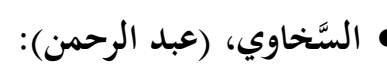

-

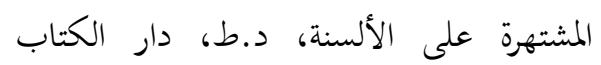

العربي، د.ت.

• الشاطبي (أبو إسحق إبراهيم بن موسى اللخمي):

- - الموافقات في أصول الشريعة، عناية الشيخ

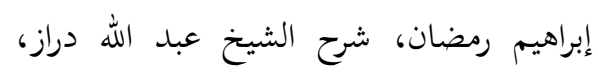

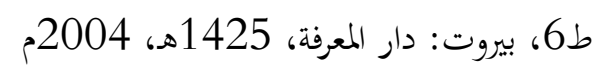

• الشوكاني (محمد على بن محمد). 
- - ل إرشاد الفحول إلى تحقيق الحق من علم

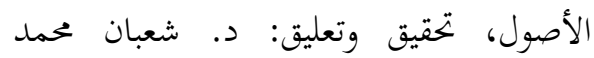

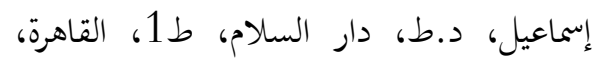

1998م.

$$
\text { • صدر الدين علي بن أبي الفرج بن الحسن البصري: }
$$

-

169، القاهرة: مكتبة الخانجي، 1420 - 1920

1999

• الطبري (أبو جعفر محمد بن جرير):

- - تاريخ الأمم والملوك، د.ط، بيروت: مؤسسة

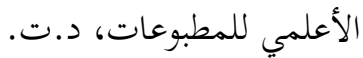

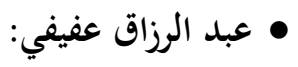

- الولاء والبراء في الإسلام، ط12، القاهرة: دار الصفوة، 1423هـ.

\section{• العثيمين (محمد بن صالح):}

- فتح ذي الجلال والإكرام بشرح بلوغ المرام،

تحقيق وتعليق: صبحي محمد رمضان، أم إسراء

بنت عرفة بيومي، ط1، القاهرة: المكتبة

الإسلامية للنشر والتوزيع، 1427هـ.

- - القول المفيد على كتاب التوحيد، تققيق:

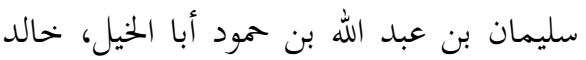

بن علي بن محمد المشيقح، ط1، الرياض: دار

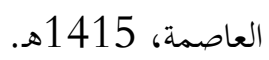


- - فهج البلاغة، شرح: محمد عبده; أشرف على

طبعه و زاد في شرحه: عبد العزيز سيد الأهل،

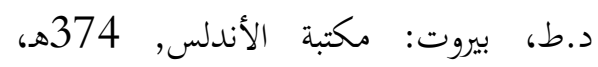

1954م. د. دئ.

• الغزالي (أبو حامد محمد بن محمد):

- إحياء علوم الدين، د.ط، القاهرة: دار الفكر

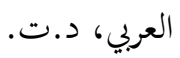

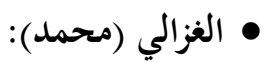

- - الإسلام والاستبداد السياسي، ط1، القاهرة:

دار غضة مصر، 1997م.

- - التعصب والتسامح بين المسيحية والإسلام،

ط12، القاهرة: دار غضة مصر، 2015م.

• الفاتيكان (المجمع الفاتيكانى الثانى):

- دستور"الوحى الإلهى"، تاريخ الإقرار

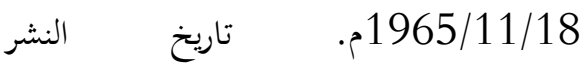

1965/12/24، نقله عن اللاتينية إلى العربية

الأب: يوسف الكلاس البولسى، ضمن كتاب

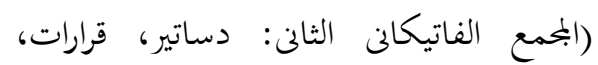

بيانات) الذى أشرف على ترجمته وقام بالقسم

الأكبر منها الأب:حنا الفاخورى، الثرق تمعهد

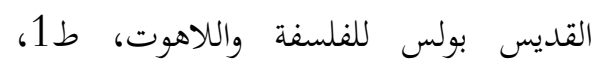

لبنان: المكتبة البولسية، 1992م. 
- الإحسان إلى مخالف الإيمان، قراءة في الكتب

المقدسة: اليهودية والمسيحية والإسلامية، العطاء

والدعاء أنموذجا، بنها: بحلة كلية الآداب

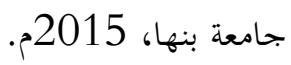

- التحية والابتسام لمخالف الإيمان، قراءة في

الكتب المقدسة: اليهودية والمسيحية والإسلامية

، السويس: بحلة كلية الآداب جامعة السويس،

2016

- التعايش مع الآخر، ط4، المدينة المنورة: دار

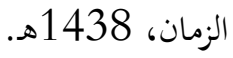

- الحوار مع الآخر: مفهومه وأهم أصوله وآدابه

وأخطائه، ط2، المدينة المنورة: دار الزمان، عام

2013

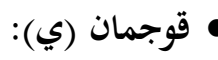

- قاموس عبري عربي، د.ط، بيروت: دار الجيل،

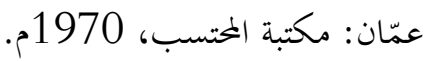

• ابن قيم الجوزية (أبو عبد الله محمد بن أبي بكر، المعروف بابن القيم):

- روضة المحبين ونزهة المشتاقين، تحقيق أحمد شمس

الدين، ط3، بيروت: دار الكتب العلمية، روته

1424هـ 
- زاد المعاد في هدي خير العباد: ط27 بيروت:

مؤسسة الرسالة، بيروت - الكويت: مكتبة فيت الكباد

المنار الإسلامية، 1415هـ /1994م.

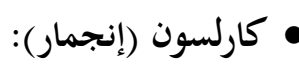

- الإسلام وأوربا: تعايش أم بحاهة، ط1،

القاهرة: مكتبة الشروق الدولية، 2003م.

• ابن كثير ( أبو الفداء إسماعيل):

- - البداية والنهاية، ط1، بيروت: دار الكتب

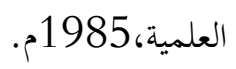

• ابن منظور ( محمدل بن مُكرَّم بن علي المصري):

- لسان العرب، ط1، بيروت: دار صادر، د.

.

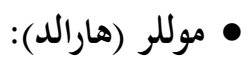

- ت تعايش الثقافات، مشروع مضاد لمنتنجتون،

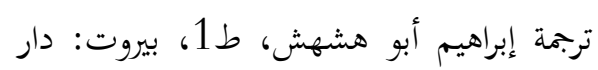

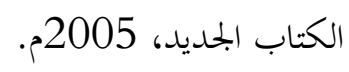

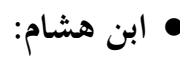

- - - السيرة النبوية تعقيق مصطفى السقا، إبراهيم

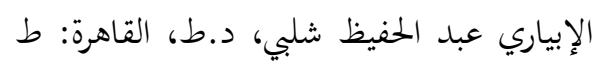

مصطفى البابي الحلبي وأولاده، د.ت.

• أبو هلال العسكري (الحسن بن عبد الله بن سهل بن سعيد): 
- - الفروق اللغوية، تحقيق: محمد إبراهيم سليم،

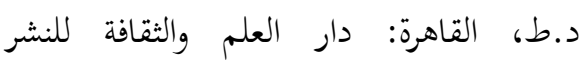

والتوزيع، 1997م، 1418هـ

• (صنتجتون (صامويل).

- صدام الحضارات، إعادة صنع النظام العالمي،

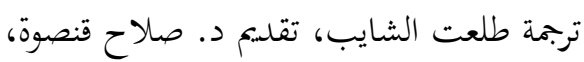

ط2، القاهرة: شركة سطور، 1999م.

• اليسوعي (الأب فاضل سيداروس اليسوعي وآخرون):

- - معجم اللاهوت الكتابي، ط2، بيروت: دار

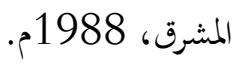

